\title{
Propelling Health Care into the Twenties
}

\author{
Denis Horgan $^{a} \quad$ Bettina Borisch ${ }^{b} \quad$ Etienne Richer ${ }^{c} \quad$ Chiara Bernini ${ }^{a}$ \\ Dipak Kalra $^{d}$ Mark Lawler ${ }^{\mathrm{C}}$ Gennaro Ciliberto ${ }^{f}$ Hendrik Van Poppelg \\ Angelo Paradiso ${ }^{\text {h }}$ Peter Riegman ${ }^{i}$ Stefano Triberti ${ }^{j}, k$ Andres Metspalu ${ }^{l}$ \\ Arturo Chiti $^{m} \quad$ Elizabeth Macintyre $^{n}$ Stefania Boccia $^{0, p} \quad$ Fabien Calvo $^{q}$ \\ Desmond Schatz $^{r}$ Jasmina Koeva-Balabanova ${ }^{s}$ Bengt Jonsson $^{t}$
}

\begin{abstract}
${ }^{a}$ European Alliance for Personalised Medicine, Brussels, Belgium; ${ }^{b}$ BioCampus, Institute of Global Health, University of Geneva, Geneva, Switzerland; ' CIHR Institute of Genetics, Ottawa, ON, Canada; ${ }^{d}$ The European Institute for Innovation through Health Data (i-HD), Gent, Belgium; eQueen's University Belfast, Belfast, UK; ${ }^{f}$ IRCCS Istituto Nazionale Tumori Regina Elena, Rome,

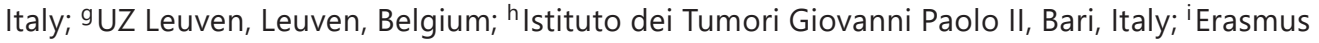
MC, Rotterdam, The Netherlands; jDepartment of Oncology and Hemato-Oncology, University of Milan, Milan, Italy; ${ }^{k}$ Applied Research Division for Cognitive and Psychological Science, IEO, European Institute of Oncology IRCCS, Milan, Italy; 'Estonian Genome Center, Institute of Genomics, University of Tartu, Tartu, Estonia; mDepartment of Biomedical Sciences, Humanitas University, Milan, Italy; ${ }^{n}$ Laboratory of Onco-Haematology, Assistance Publique-Hôpitaux de Paris (AP-HP), Paris, France; ${ }^{\circ}$ Sezione di Igiene, Dipartimento Universitario Scienze della Vita

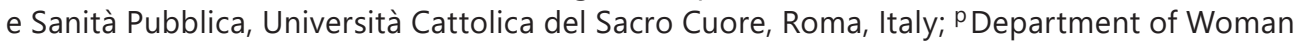
and Child Health and Public Health - Public Health Area, Fondazione Policlinico Universitario A. Gemelli IRCCS, Roma, Italy; ${ }^{9}$ CancerCore Europe, Paris, France; ' $D$ epartment of Pediatrics, University of Florida, Gainesville, FL, USA; ${ }^{\mathrm{s} B u l g a r i a n}$ Alliance for Personalised and Precision

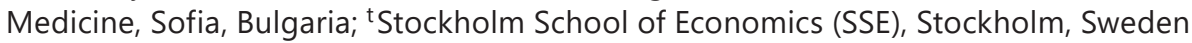

\section{What Is It about?}

Making the Future Bright for Personalised Health Care

Europe is facing health challenges of increasing scope and complexity. There is an urgent need to improve the safety, quality, sustainability, and effectiveness of health care in order to tackle these challenges. Despite this being the wave of the future, across the EU the picture is fragmented. The overarching aim of the article is to ensure that future policies can support an environment that will facilitate innovation, investment, and incentives (dubbed the 3 i's). In order to provide a clear focus and to devote sufficient space to analysis, the article concentrates on how:

- to assess and address obstacles to the integration of personalised health care into Europe's health care systems;

- $\quad$ to outline the potential benefits, competitiveness of Europe and its impact on policy making in terms of future-proofing the policy arena as well as access. 


\section{Keywords}

Health policy, regulatory - Member states · Innovation - European Commission · Incentives - Personalised medicine - Precision medicine - Preventive medicine - Public health . Pharmacoeconomics · Health economics - Frameworks - Reimbursement · Personalised health care · Diagnostics · Biomarkers, optimal $\cdot$ Real-world data $\cdot$ Data-translational research $\cdot$ Empowerment patient $\cdot$ Citizens $\cdot$ Access

\section{Abstract}

The scope and potential of personalised health care are underappreciated and underrealised, often because of resistance to change. The consequence is that many inadequacies of health care in Europe persist unnecessarily, and many opportunities for improvement are neglected. This article identifies the principal challenges, outlines possible approaches to resolving them, and highlights the benefits that could result from greater adoption of personalised health care. It locates the discussion in the context of European policy, focusing particularly on the most recent and authoritative reviews of health care in the EU Member States, and on the newly acquired spirit of readiness and pragmatism among European officials to embrace change and innovative technologies in a new decade. It highlights the attention now being given by policymakers to incentives, innovation, and investment as levers to improve European citizens' prospects in a rapidly evolving world, and how these distinct and disruptive themes contribute to a renaissance in thinking about delivering optimal health care in Europe. It explores the chances offered to patients by specific initiatives in health domains such as cancer and antimicrobial resistance, and by innovative science, novel therapies, earlier diagnosis tools, and deeper understanding of health promotion and prevention. And it reflects on how health care providers could benefit from a shift towards better primary care and towards deploying health data more effectively, including the use of artificial intelligence, coupled with a move to a smoother organisational/regulatory structure and realigned professional responsibilities. The conclusion is that preparing Europe's health care systems for the inevitable strains of the coming years is both possible and necessary. A more courageous approach to embracing personalised health care could guarantee the sustainability of Europe's health care systems before rising demands and exponential costs overwhelm them - an exercise in future-proofing, in ensuring that they are equipped to withstand whatever lies ahead. A focus on the potential and implementation of personalised care would permit more efficient use of resources and deliver better quality health-preserving care.

\section{Introduction}

The potential of personalised health care is almost unlimited. New understanding of disease epidemiology and pharmacogenomics, the deployment of technologies such as genomics, single cell sequencing, microbiome analysis and transcriptomics, and the opportunities arising from bioinformatics and digital innovations to enhance precision medicine can be transformative for the care of individual patients. It could deliver equivalent benefits for the citizen, through public health initiatives that empower disease prevention, prediction of risk, and promotion of healthy lifestyles. A personalised approach to health care could prompt progressive adaptations in health care delivery organisation, built on the pillars of crossfertilisation and collaboration between disciplines and professions, greater patient participation in their own care, and a more comprehensive appreciation of the strategic direction and funding challenges that underpin health care systems change to a more personalised approach. 
Fig. 1. Comparative and growth rates of scientific publications, highly cited scientific publications, researchers, patent applications and value added of hightech sectors in the EU and the USA. PCT, Patent Cooperation Treaty; FTE, full time equivalent. Source: European Commission, DG Research and Innovation. Data: Eurostat, OECD, CWTS based on Web of Science database.

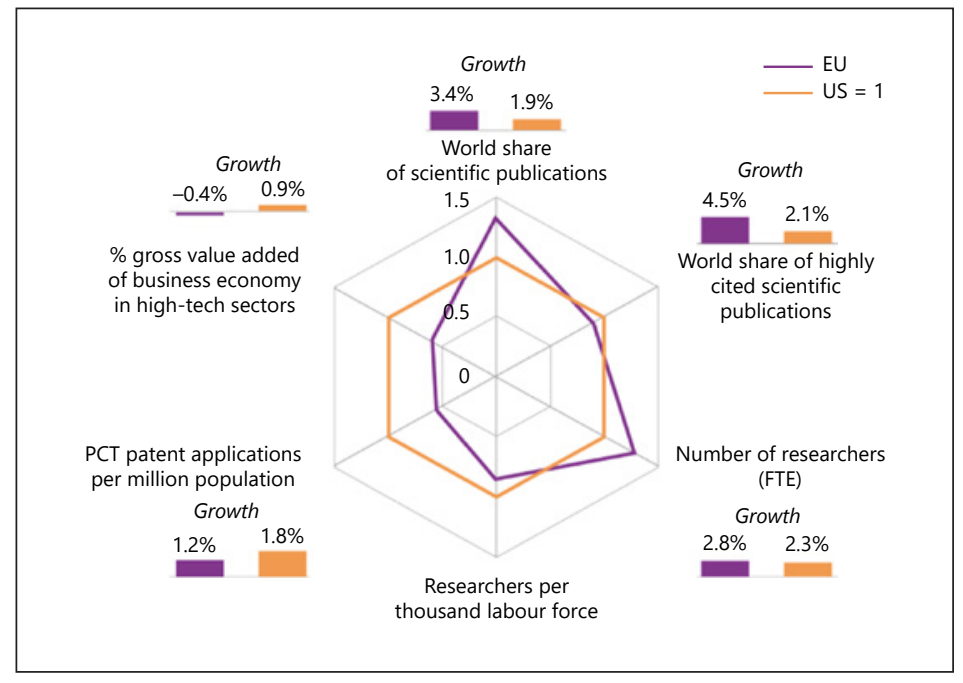

But health care systems are not always ready to respond to the opportunities that are presented. The disruptive nature of personalised care challenges the traditional patterns of thinking in this domain. Practices, presumptions, and even prejudices that date from before the millennium, tend to resist a 21st century approach to health care. A revised policy framework is needed to realise the potential of personalised health care - and not only in Europe: Europe's engagement in global research and scientific enterprise can benefit the population of the entire planet.

Now, at the start of the 2020s, wide-ranging changes are under way in European society and governance, with a new European Commission, a freshly elected European Parliament, and a growing conviction among Europe's policymakers that people must be at the centre of any successful and sustainable research implementation strategy. The ambition of new Commission President Ursula von der Leyen is a Europe that "must lead the transition to a healthy planet and a new digital world" [1], while Health Commissioner Stella Kyriakides acknowledges that "European citizens expect the peace of mind that comes with access to health care ... and protection against epidemics and diseases" [2]. Expectations have been heightened by European strategists' attachment to three key ingredients for courageous transformation: incentives, innovation, and investment. These reflect the preconditions for boosting health care into higher levels of efficiency, where the value of personalised medicine approaches can be fully appreciated and ensure its full contribution to the benefit of Europe's citizens.

This landscape of personalised health care depicts a Europe where many chances for improvement are not yet fully being realised. But this is not merely a catalogue of deficiencies. The variations and inefficiencies that underpin potential lost opportunities are an argument for triggering radical rethinking, and for making the most of personalised health care. It highlights how the endorsement of incentives, innovation, and investment by a new breed of Europe's leaders could help support the development of innovative diagnostics and medicines, ushering in an era of citizen-focused personalised health care.

Ultimately, it is a clear reminder that people in Europe - and beyond - can, if access is simplified, democratised and streamlined, enjoy potentially better health care, with greater access to new innovations, thus leading to more healthy lives. The options for targeting care to the individual patient and for taking a more comprehensive and multi-stakeholder view are within grasp. But it requires a greater readiness to entertain new ways of thinking, of deploying resources, and, most crucially, the resolution to act. Everyone - from newborn babies to the elderly, from sufferers from chronic disease to acute cancer patients, and from 
Fig. 2. Estimate of the incidence of prostate cancer in men, 2012. Source: EAU, Prostate Cancer, recommendations to lower the risk and mortality rate of the most frequent cancer in men.

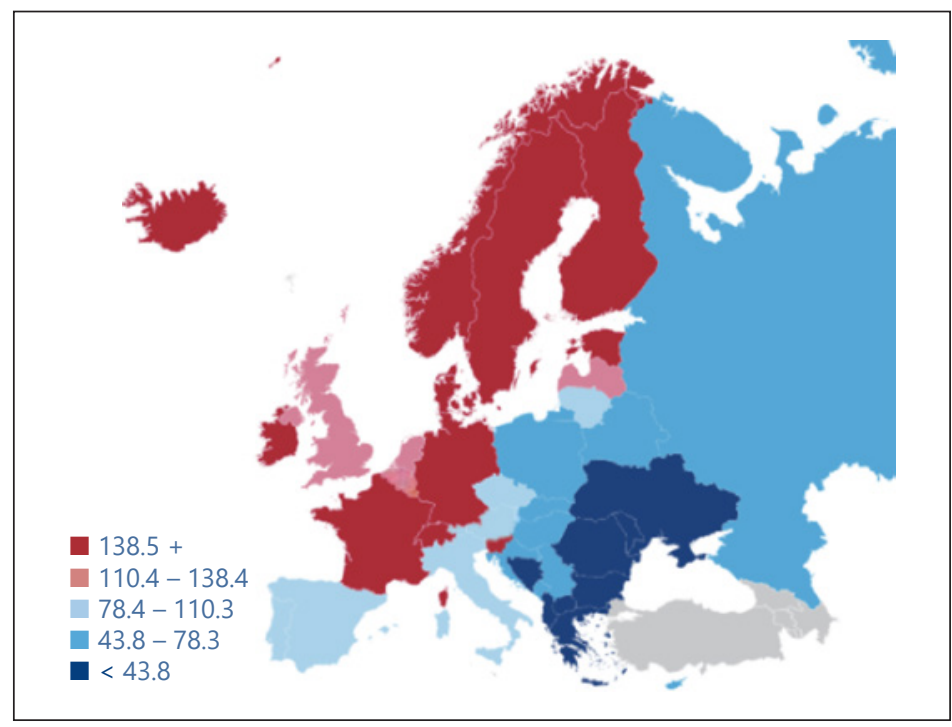

Fig. 3. Estimate of the mortality from prostate cancer in men, 2012. Source: EAU, Prostate Cancer, recommendations to lower the risk and mortality rate of the most frequent cancer in men.

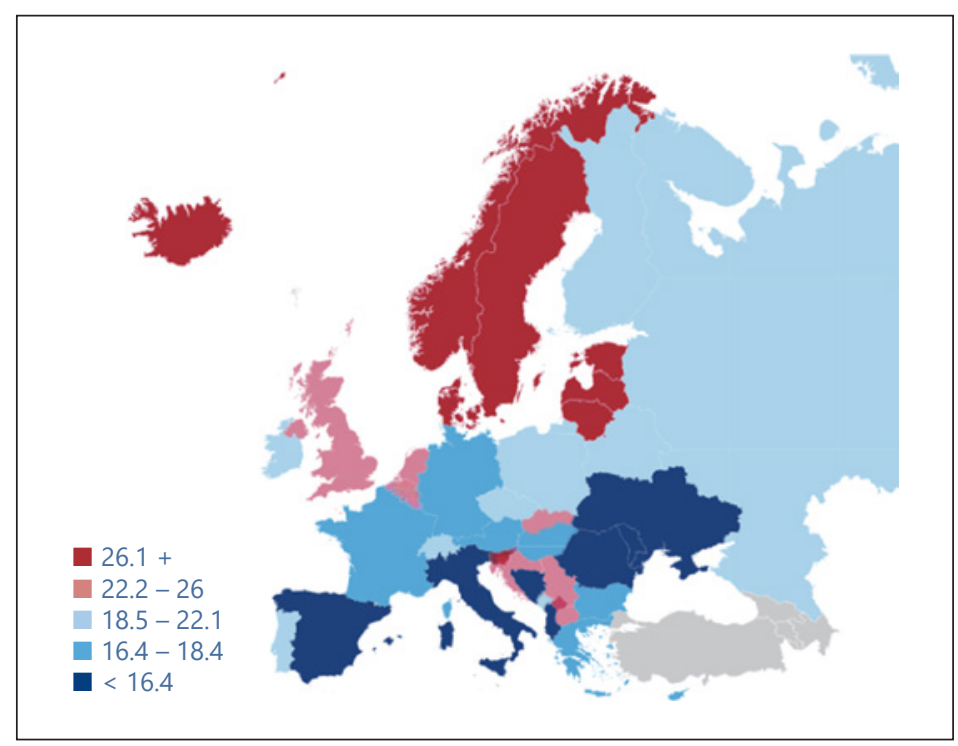

health ministries to funding agencies - stands to gain. The price is nothing more than a shift in policy. The prize - in terms of value to the economy and to lives - is priceless.

\section{Europe Unfulfilled}

Chances Are Being Missed to Deliver the Best Care to Patients, because Suboptimal Health Data Are Allowing Unnecessary Gaps to Persist in Health Care Provision in Europe

The panorama of Europe's health care in 2020 is full of contrasts, between huge advances driven by science, research, the health care workers and public policy (Fig. 1 displays the vigour of EU scientific research in the international context), and gaps where illness goes untreated or undetected until too late, or where regions and sections of society enjoy less access or fewer benefits. 


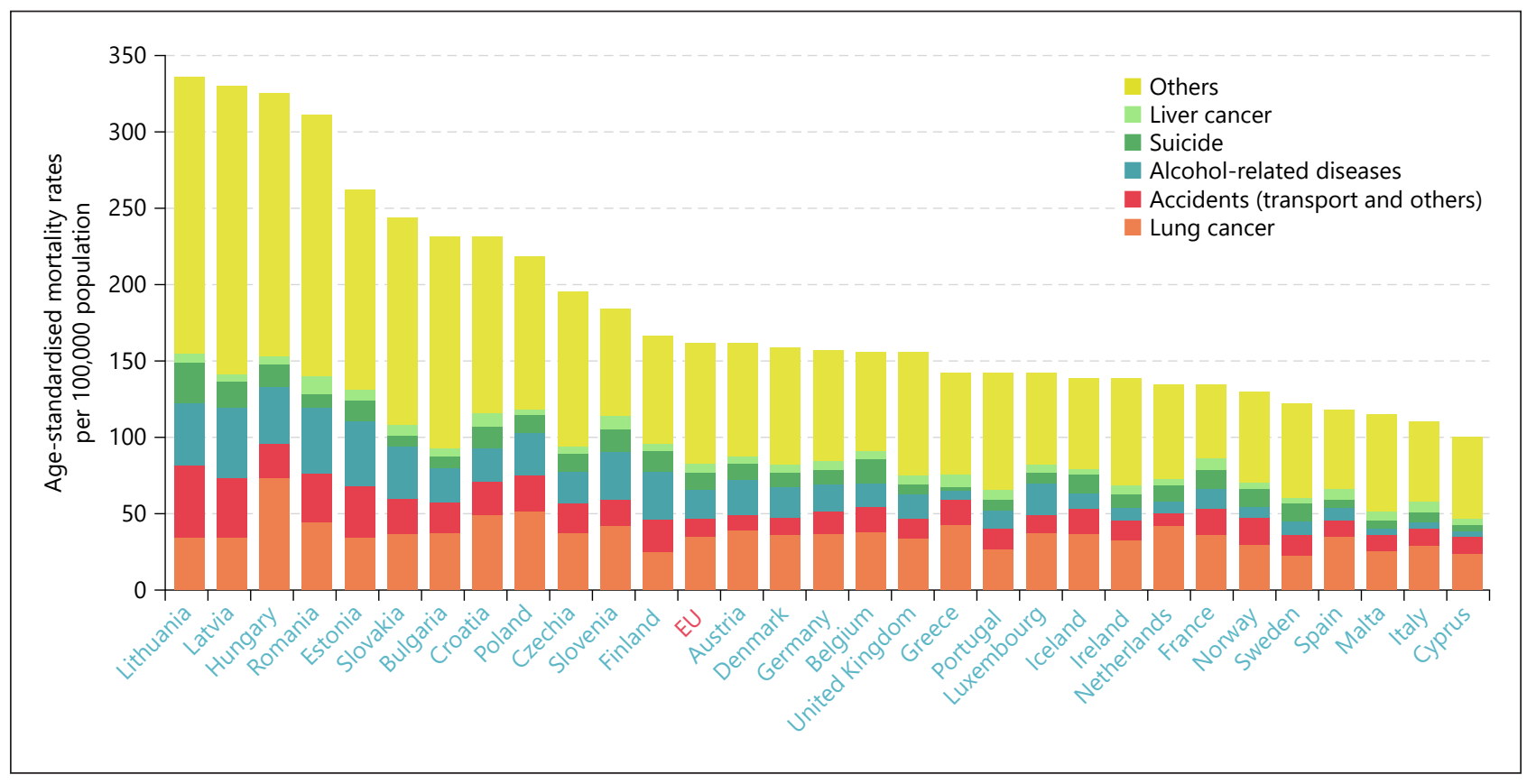

Fig. 4. Preventable mortality in the EU, 2019.

Certain aspects of progress are dependent on science. But some answers are already available: improvements could come from better organisation and/or better use of resources. The OECD Companion Report on Health in Europe recognises with approval EU-level efforts to bring promising health care products to the market sooner [3]. But the use of promising products is not always as widespread as it might be, leading to suboptimal care and disappointment.

Variations in coverage/effective screening/diagnosis/treatment of disease demonstrate how uneven health provision is among Europe's citizens. Wide disparities are evident, whether in average length of hospital stays - ranging from 4.5 days in the Netherlands to 9.8 days in Hungary - or in screening rates for breast cancer - Spain's former health minister and now prominent member of the European Parliament, Dolores Montserrat, has pointed out that cancer patients in Central and Eastern Europe have 30\% less chance of being successfully treated than in Western Europe [4]. Similarly, wide variations are seen in the incidence (Fig. 2) and mortality (Fig. 3) in prostate cancer across Europe.

The availability of essential medicines and the uptake of innovative therapies also vary widely, as do the market presence and coverage at the national level of centrally authorised medicines. Diversity of opinion and practice characterises national beliefs and knowledge about vaccination too, with Portugal, Denmark, and Spain enjoying conspicuously higher levels of confidence on average than Bulgaria, Latvia and France. Such variations pose challenges for awareness raising and the acceptance of scientific evidence [5] as well as for health care system management. In some countries, preventable mortality is more than twice the EU average (Fig. 4).

\section{Future-Proofing the Health Care Arena}

Improvement

Member States are improving performance, and EU assistance is helping refine health system organisation, allocation of resources, skills mix, and deployment of technology - from 


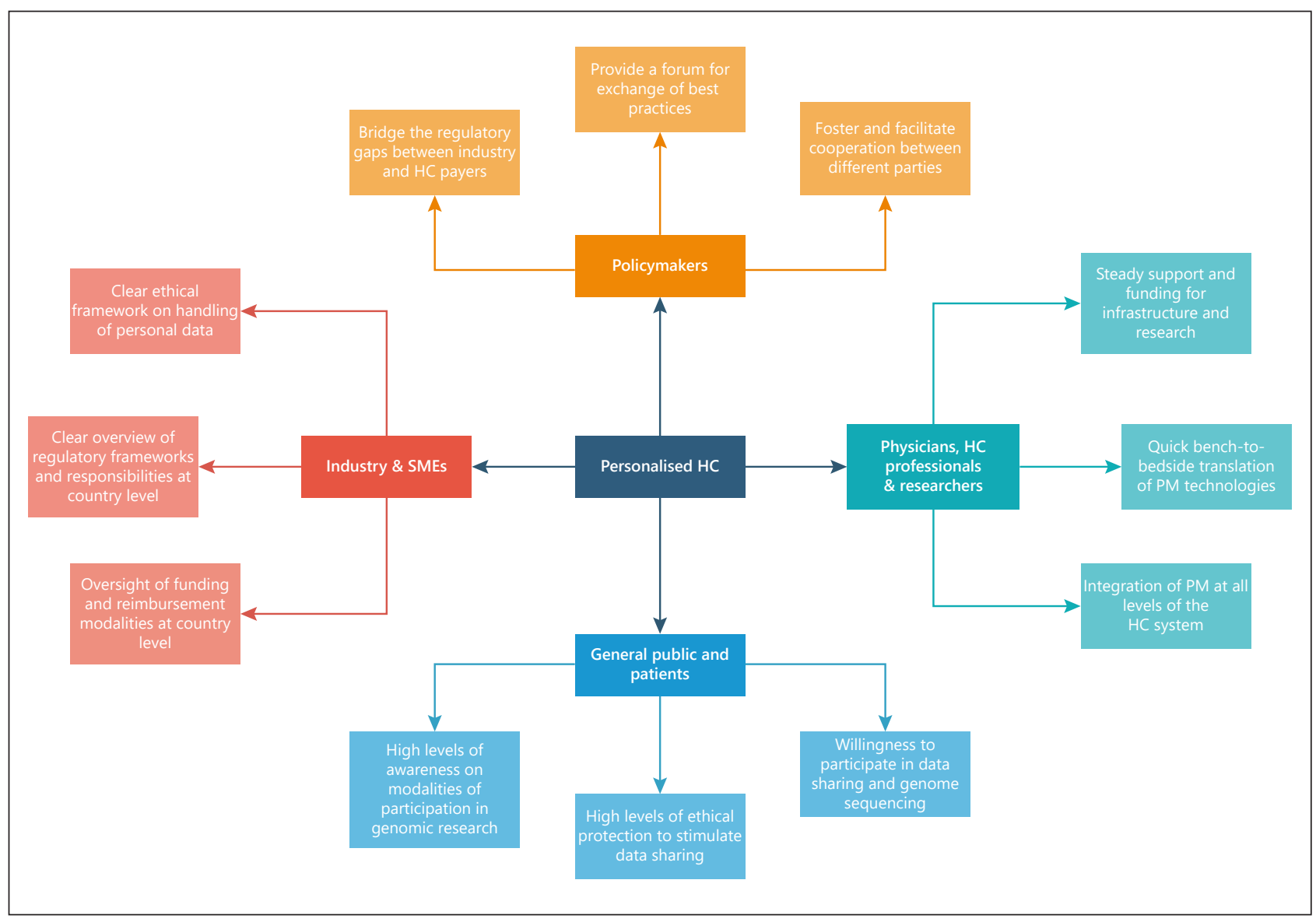

Fig. 5. Personalised health care (HC) mosaic. SME, small and medium enterprises; PM, personalised medicine. Source: Horgan et al. [150].

digital and artificial intelligence to new medicines and diagnostics. This requires unprecedented cooperation: the multiplicity of stakeholders that need to be involved in bringing real innovation to Europe's health care systems is neatly indicated in Figure 5.

\section{Incentives}

The incentives for improvement are evident. Impending demographic challenges and chronic disease oblige health services to focus more on prevention and planning of more individualised treatment pathways. Populations will lead healthier, longer, and more productive lives by avoiding smoking, overeating and obesity, by regular exercise and better health care system performance. Difficulty frequently arises, however, in translating these concepts to the practical level of health care planning and delivery in all its many configurations at national, regional, and local levels. As an example, Figure 6 indicates the complexity in introducing biomarker testing for companion diagnostics, drawn from a European review of conditions required for progressing personalised medicine (Table 1).

\section{Innovation}

The merits of innovation - in health care planning and management, as well as in improving care quality and hardware or embracing the innovations offered by digitalisation - are a frequent theme among Europe's policymakers. As the latest European Innovation Scoreboard points out, successful innovation requires the right combination from a 
Biomedicine

Hub

Horgan et al.: Propelling Health Care into the Twenties

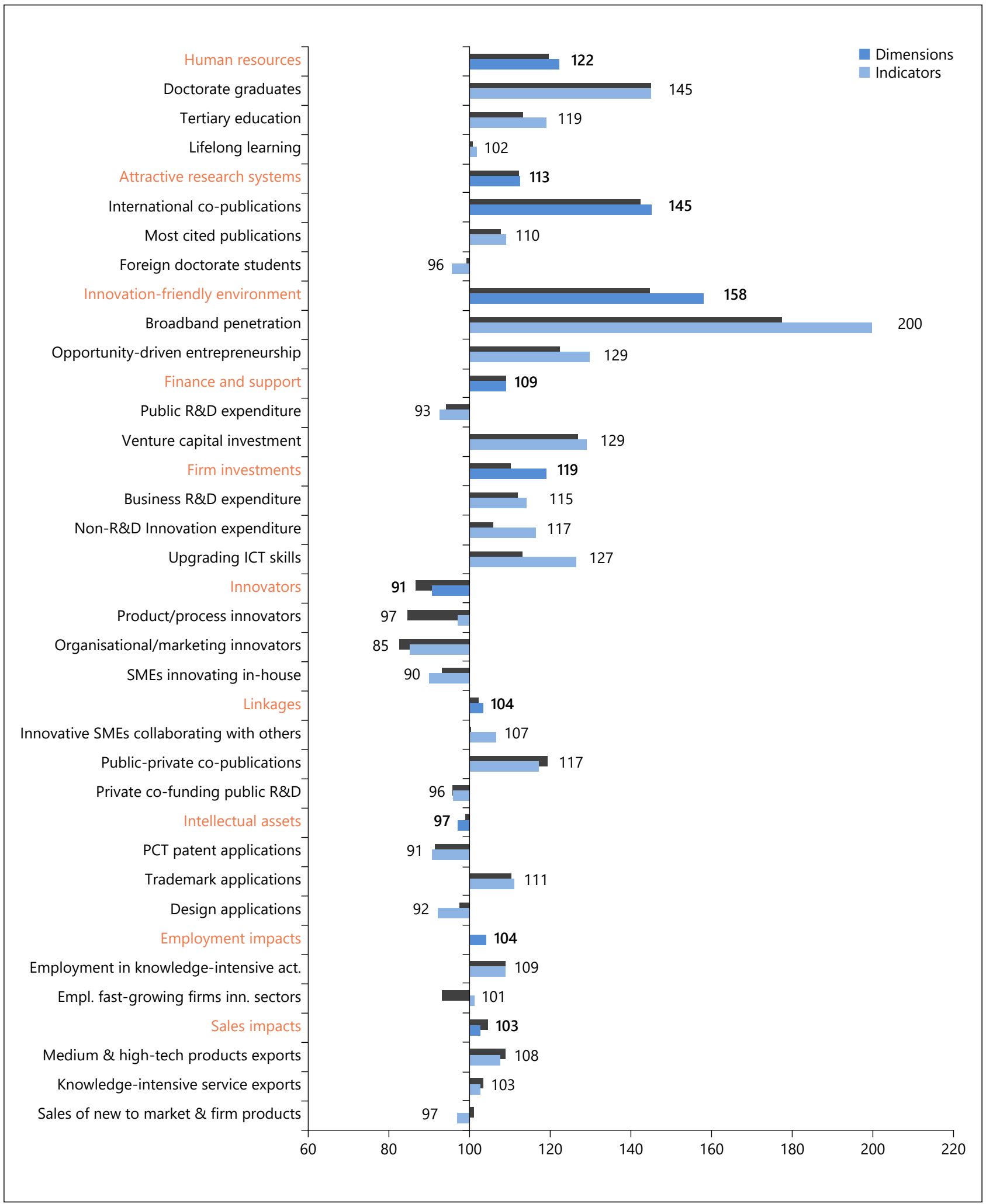

Fig. 6. EU performance change between 2011 and 2018 by dimension and indicator. Source: European Commission [151]. 
Table 1. Listing of the summary points from the literature review concerning PM and biomarker testing for $\mathrm{CDx}$

\begin{tabular}{|c|c|c|}
\hline Level & Section & Summary points \\
\hline \multirow[t]{3}{*}{ Scientific } & $\begin{array}{l}\text { System biology/ } \\
\text { medicine and data } \\
\text { science }\end{array}$ & $\begin{array}{l}\text { Integrated analyses; health data; biomarkers; informational } \\
\text { structured model; drug development process; HTA framework }\end{array}$ \\
\hline & Research & $\begin{array}{l}\text { Different regulatory processes; business models; company } \\
\text { cultures; clinical relevant information, CER, EMR; informed } \\
\text { consent; interoperability }\end{array}$ \\
\hline & Clinical study design & Standards, methodologies, harmonization; guidelines \\
\hline \multirow[t]{4}{*}{ Operational } & Information delivery & $\begin{array}{l}\text { CDS; infrastructure; limited resources; databases; secure } \\
\text { environment; turnaround time tests }\end{array}$ \\
\hline & Education and training & $\begin{array}{l}\text { Health care professionals; lack of knowledge; interpretation; } \\
\text { sense of competence; communication; multidisciplinary team } \\
\text { training; curricula of medical schools }\end{array}$ \\
\hline & $\begin{array}{l}\text { Inform, educate, } \\
\text { empower patients }\end{array}$ & $\begin{array}{l}\text { Low awareness; health literacy; privacy regulations; reduce } \\
\text { concerns }\end{array}$ \\
\hline & Regulations & $\begin{array}{l}\text { Guidelines; lack of consensus; outdatedness; adherence; } \\
\text { standards for practice; clinical study design; infrastructure of } \\
\text { biobanking; ethical and legal issues; automated CDS }\end{array}$ \\
\hline Economic & Reimbursement & $\begin{array}{l}\text { Lack of evidence; incentives; streamline; market-based } \\
\text { approaches; HTA; approval process }\end{array}$ \\
\hline \multirow[t]{4}{*}{ European } & Biobanks & $\begin{array}{l}\text { Lack of standardization; international interoperability; } \\
\text { regulatory procedures; infrastructure; management; cost } \\
\text { investment; EU-funding procedures }\end{array}$ \\
\hline & Translation & Cross-border data collection and sharing; HTA framework \\
\hline & Reimbursement & $\begin{array}{l}\text { Reimbursement models; national health care systems; } \\
\text { exchanging information; timely access (patients); market access }\end{array}$ \\
\hline & Legal and ethical & $\begin{array}{l}\text { Sharing confidential data; EU directive; legal frameworks for } \\
\text { tests and treatments; privacy; IP; researchers' accessibility; } \\
\text { different legislations; ethics }\end{array}$ \\
\hline
\end{tabular}

PM, personalized medicine; CDx, companion diagnostic; HTA, health technology assessment; CER, clinical evaluation report; EMR, electronic medical record; CDS, clinical decision support; IP, intellectual property.

complex of distinct factors, ranging from intellectual assets and human resources to innovation-friendly environments and attractive research systems. "We need to embrace innovation to support sustainable growth and maintain a globally competitive industry," says the Commission in the introduction.

Figure 6 displays how the EU as a whole has performed as an innovation system over a recent decade on the full range of these factors. The overall picture is positive, with a nearly 9\% improvement between 2011 and 2018, and a strong record in the environment, human resources, and investment. But there has been a decline in patent applications and in innovators. Europe's cumulative strengths are significant, but they are eminently perfectible.

When observed at a national rather than a cumulative level, the variability of Europe's innovation capacities and record is even more striking. Figure 7 clearly shows the countries 
Fig. 7. Map showing the performance of European and neighbouring countries' innovation systems. Source: European Commission [151].

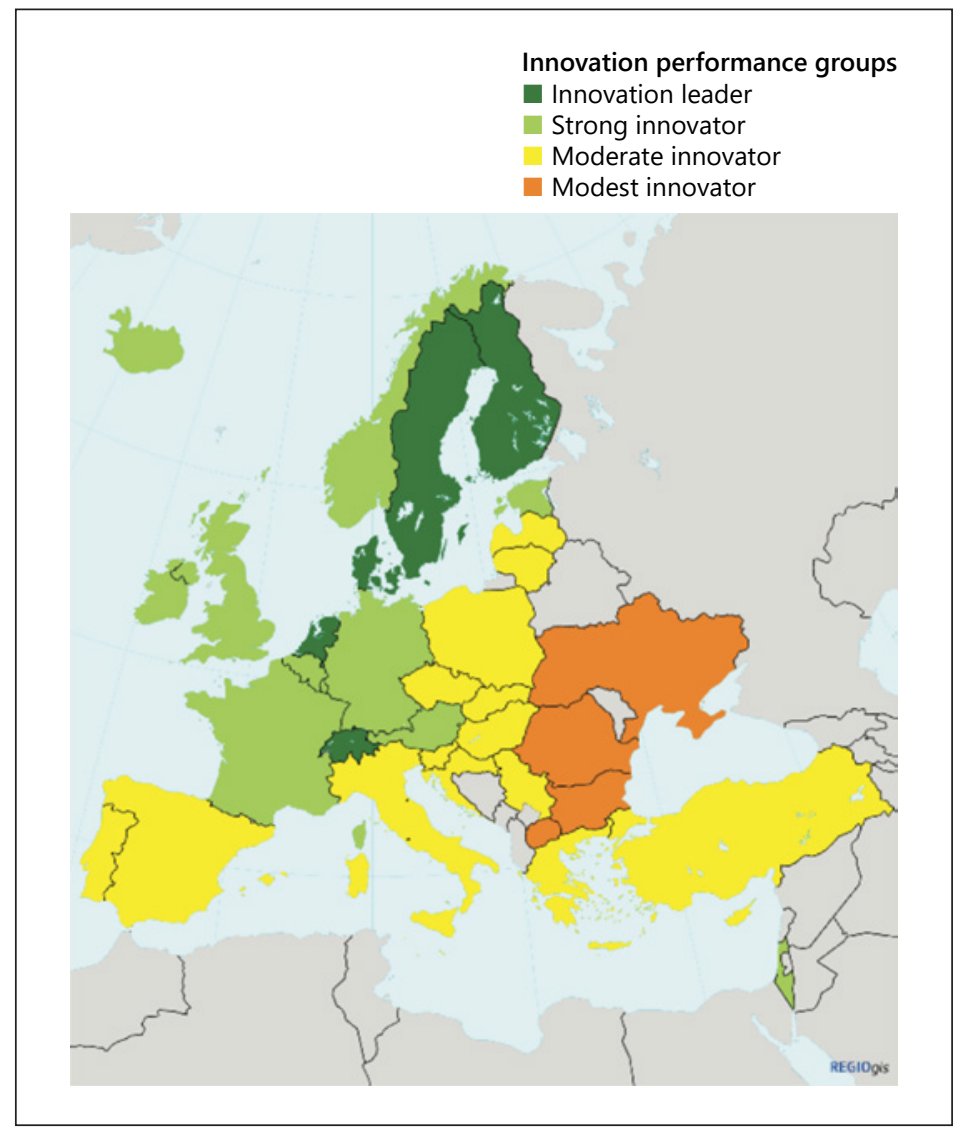

Table 2. Funding for cancer research in EU 2005 and 2015

\begin{tabular}{lcc}
\hline Million euro source of funding & 2005 & 2015 \\
\hline Public & 1,000 & 1,500 \\
Private non-profit & 900 & 1,800 \\
Private for profit & $2,200(10 \%$ of total $)$ & $8,500(25 \%)$ \\
Total & 4,100 & $11,500-16,800$ \\
\hline
\end{tabular}

where the greatest innovation strengths are - and where they are not. It is notable that non-EU Switzerland features among the leaders, defined as performance above $120 \%$ of the EU average (Switzerland is in fact the leader, with high performance on 7 of the 8 factors in Fig. 6). The strong innovators perform at $90-120 \%$ of the EU average. It is remarkable that 14 EU countries are only moderate innovators, with performance at $50-90 \%$ of the EU average, and 2 countries are the "modest" innovator group with performance below $50 \%$ of the average. "Progress remains uneven with the EU members" says the Commission. This uneven performance is inevitably a matter of concern not just to Europe's policymakers; it also has implications for innovations in health care.

Investment

Investment underpins many of the breakthroughs in science and technology that have opened the door to personalised health care. The revolutionised understanding is the consequence of conscious investment decisions in the public and private sector. During the last 


\begin{tabular}{|c|c|c|c|}
\hline FP7 (2007-2013) & & Horizon 2020 (2014-2020) & \\
\hline $\begin{array}{l}\text { Main programme } \\
\text { sections }\end{array}$ & $\begin{array}{l}\text { Budget } \\
\text { (billion } \\
\text { EUR) }\end{array}$ & Main programme sections & $\begin{array}{l}\text { Budget } \\
\text { (billion } \\
\text { EUR) }\end{array}$ \\
\hline Cooperation & 32.4 & Societal challenges & 29.7 \\
\hline $\begin{array}{l}\text { Of which for the 'health } \\
\text { theme', incl. IMI }\end{array}$ & 6.1 & $\begin{array}{l}\text { Of which for the 'health, demographic change } \\
\text { and well-being challenge', incl. IMI2 }\end{array}$ & 7.4 \\
\hline $\begin{array}{l}\text { Funding for PM research } \\
\text { in the 'health theme', } \\
\text { including IMI }\end{array}$ & 1.7 & $\begin{array}{l}\text { Funding for PM research in the 'health, } \\
\text { demographic change and well-being challenge, } \\
\text { incl. IMI2 projects so far }\end{array}$ & 0.92 \\
\hline Ideas & 7.5 & Excellent science & 24.4 \\
\hline People & 4.8 & Industrial leadership & 17 \\
\hline Capacities & 4.1 & European institute of technology & 2.7 \\
\hline Joint research centre & 1.7 & Other (incl. JRC) & 3.2 \\
\hline Total & $50.5^{\dagger}$ & Total & $77^{\dagger}$ \\
\hline \multicolumn{4}{|c|}{$\begin{array}{l}\text { †The budget allocations to the EURATOM programmes addressing nuclear research are not included, since } \\
\text { they are covered by separate legal instruments. }\end{array}$} \\
\hline
\end{tabular}

Fig. 8. Budget allocation FP7 and Horizon 2020, 2017. Source: Nimmesgern et al. [152].

decade, the fast growth in investments in the for-profit life science industries, particularly the pharmaceutical industry, has outpaced the slow growth in public-funded cancer research in most countries. European private-sector investments in cancer research, for instance, are estimated to have grown more rapidly in recent years [6] (Table 2).

The EU has contributed significantly to this research too, with programmes such as its Horizon framework programme, which has invested more than EUR 8 billion directly in health in its current cycle (Fig. 8). There is still a long way to go, however, in directing investment to its most useful purpose across the broad field of health care - in everything from supporting research to reducing fragmentation, and from efficient regulation to implementing and adopting innovative health care technology. These efforts could provide pathways to new and more effective structures for health care for Europe.

\section{Europe's Pinch-Points}

Many aspects of European health care need improvement if better care is to be achieved for the European citizen. Issues such as variability of care from country to country and disease to disease, persistent unhealthy lifestyles, barriers to accessing health care, and fragmented and uncoordinated organisation of health services must be addressed in a timely and 


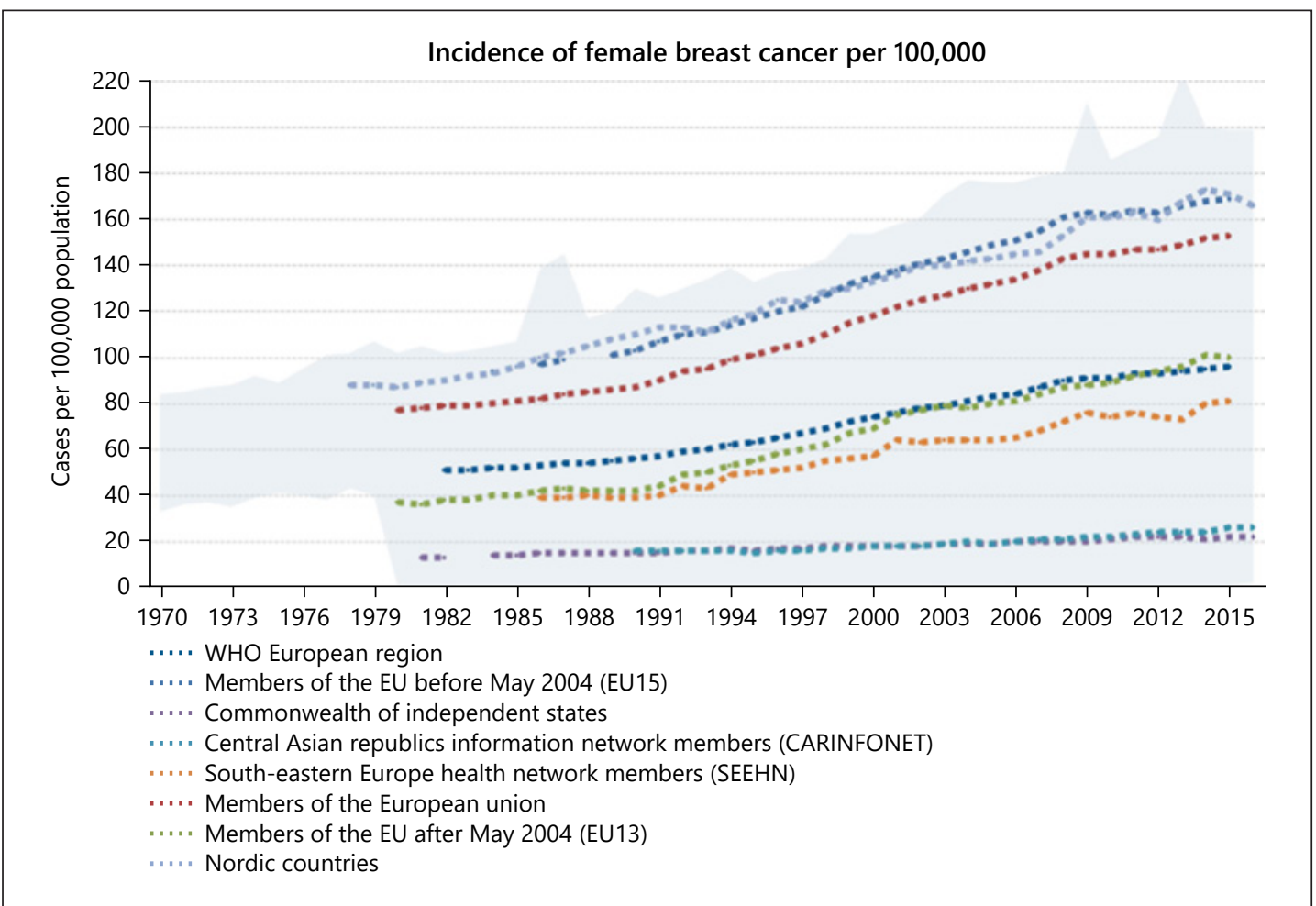

Fig. 9. Incidence of female breast cancer per 100,000. Source: WHO [153].

coherent fashion. Data on care delivered and outcomes achieved are frequently lacking or incoherent, and investment, particularly day-to-day funding, is often inadequate or suboptimally directed.

\section{Wide Variability}

A major impediment is the wide variability across Europe in treatment options, in health care performances, and in inefficiencies. A recent survey highlighting many of these disparities [7] showed that in breast cancer, Sweden and Belgium score 69 on a broad 100-point index (Fig. 9), but Hungary scores only 37, while most countries score between 60 and 53. Sweden and Estonia perform well specifically for home care, while Belgium and Ireland do well on hospital care [8].

The World Health Organisation's Europe Region has compiled the chart in Figure 9 highlighting the variations in the incidence of female breast cancer per 100,000 across the region, the EU, the EU15, the countries that joined the EU after 2004, the Nordic countries, and different configurations of south-east Europe and central Asia. While there is an increase everywhere, the disparities in the actual rate and the growth over time demonstrate the variability and suggest how influential local conditions are.

A parallel analysis of multiple sclerosis (summarised in Fig. 10) found a similarly wide range: Germany performs well, at 71 on a 100-point index, but Malta trails at a lowly 18. The UK comes in last on the number of neurologists and on the proportion of multiple sclerosis patients in active work [9]. A third index - on "sustainability" (summarised in Fig. 11) explores access, health status, and innovation, and Norway and Switzerland establish a high benchmark in the 70s, against a mean of 55, and a bottom end in the 30s. Again, big disparities emerge, particularly in access and in innovation [10]. 


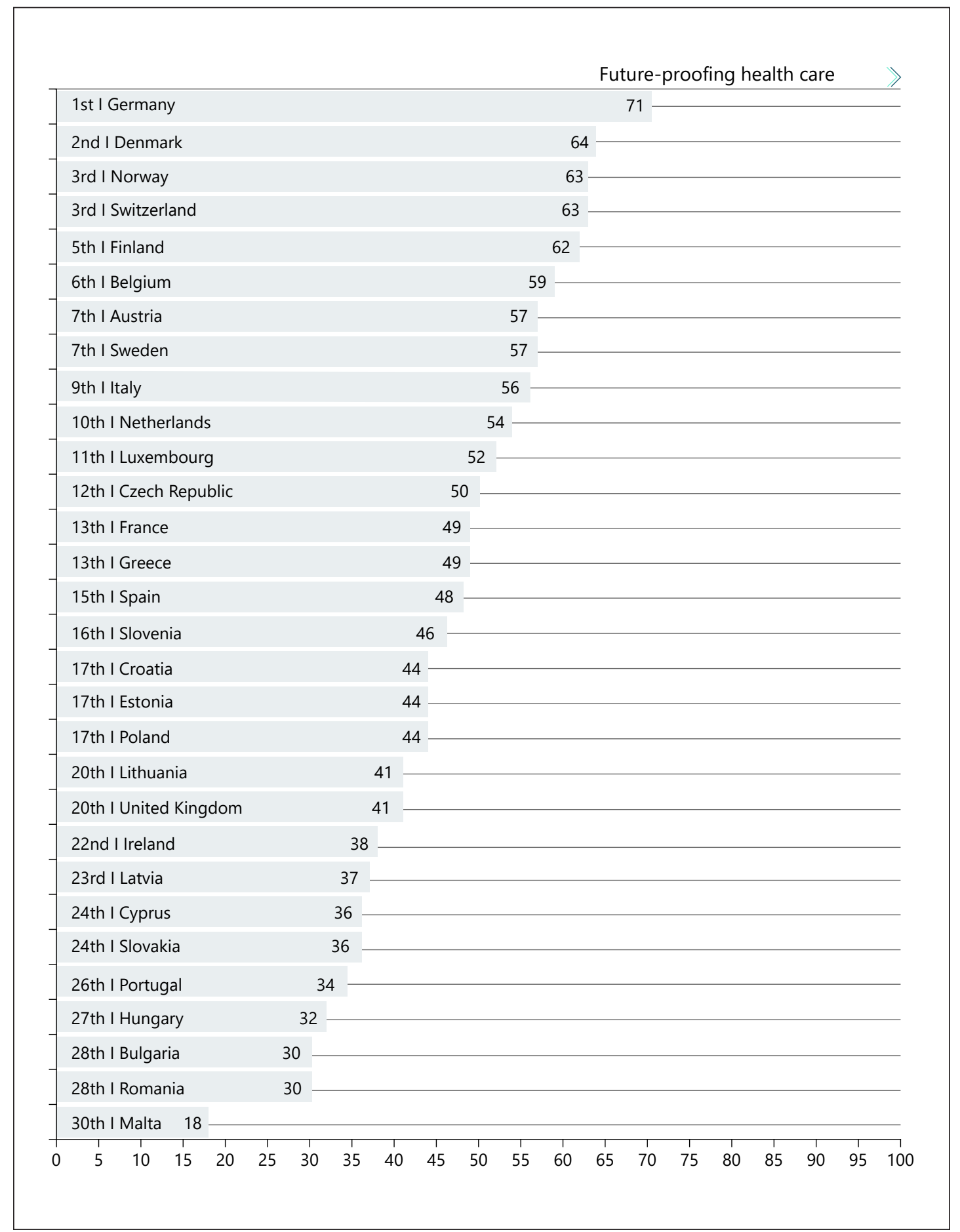

Fig. 10. Multiple sclerosis index, 2019. Source: Roche [154].

A more general problem in assessing health system performance and the effectiveness of decisions on individual therapy is the irreproducibility of results, which persists despite extensive discussion, particularly because of the samples used, and often invalidating the result of a diagnostic test or newly identified biomarker - leading to suboptimal patient treatment. 


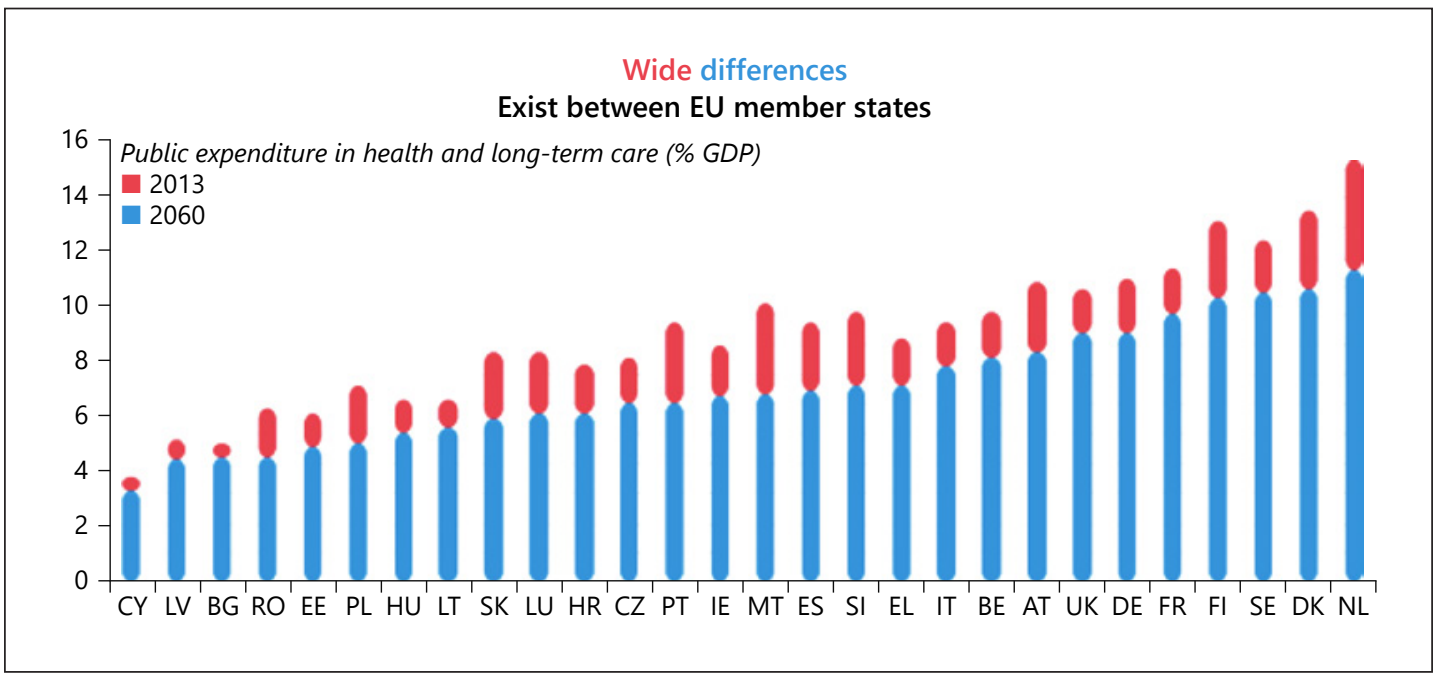

Fig. 11. Public expenditure in health and long-term care (\% GDP), 2016. Source: European Commission [155].

\section{Health systems and fiscal sustainability}

Health-related expenditure takes up a significant share of resources in the EU. This is projected to greatly increase in the coming decades.

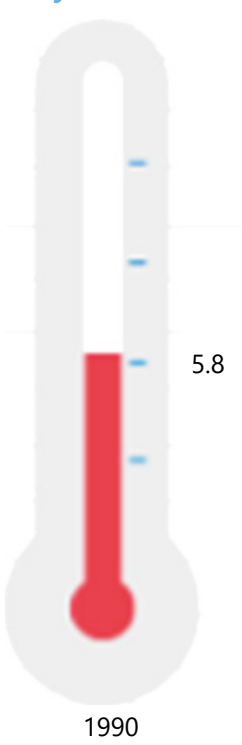

Public expenditure in health and long-term care (\% GDP)

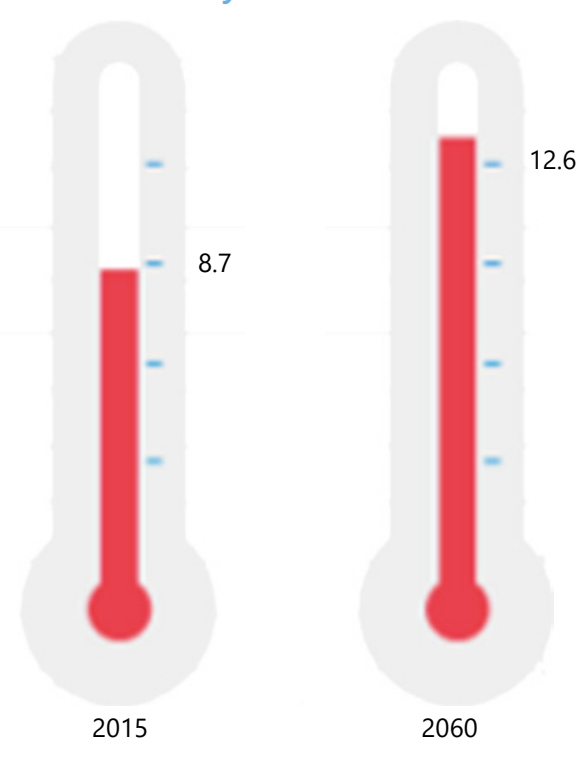

Fig. 12. Public expenditure in health and long-term care (\% GDP), 2016. Source: European Commission [155].

Figure 11 draws attention not only to recent disparities in public spending on health and long-term care across the EU Member States, but also to the expected persistence and even reinforcement of those disparities in the coming decades. And as the projection in Figure 12 suggests, the general trend towards greater spending on health as a proportion of gross domestic product (GDP) spells trouble for fiscal sustainability in the years ahead. As the European Commission suggests alongside its figures, smart health is likely to provide increased value for money into the future. 
Still wider divergences in health system performance emerge from the national profiles compiled for the State of Health in the EU, and from the EU's Companion Report that accompanied them. A heavy burden of health challenges is listed, with gains in life expectancy showing a reduced trajectory, and persistent difficulties in preventing risk factors. A comparison of per capita spending demonstrates still more sharply the variations in spending opportunities, for example on international health technology, between richer and poorer countries in Europe. According to Vytenis Andriukaitis, the outgoing EU health commissioner: "Inequalities between and within countries are widening," including in "misconceptions and scepticism" surrounding vaccination, and "difficulties in properly harnessing the digital transformation" [11].

\section{Slow Adaptation of Systems}

The OECD report highlights divergences in national health spending (Fig. 12), and explores trends and bottlenecks observed in EU Member States' health care provision. Austria's health system suffers from structural and financial fragmentation [12]. Belgium has scope for improving coordination to strengthen prevention [13]. Divided responsibilities in Czechia impede planning [14]. Germany's numerous payers and providers impede integrated evaluation and assessment, preventing health system improvements [15]. In Italy, better coordination across the country in the development of digital health solutions could help improve access and efficiency in health service delivery [16]. The Netherlands should align system incentives [17]. Poland lacks a unified strategic vision for the health system, and even Sweden needs to improve care coordination [18].

Insufficient promotion of prevention and healthy lifestyles and neglect of primary care providers and outpatient care mean missing chances for better use of resources. In Poland, the shift to more community-based care has not yet materialised [19]. In Bulgaria, about one fifth of hospital procedures could be implemented in outpatient care [20]. In Croatia, primary care is fragmented and underutilised [21]. Denmark's generally high-quality health system still has scope for improvement in care coordination outside hospitals [22]. In Germany, the large provision of inpatient services raises doubts about best utilisation of resources [23]. Across Europe, the data reinforce the signal that there is room for efficiency gains in health services and a need for greater investment in modernisation of these services.

\section{Potential in the Organisation of Health Care}

The organisation of health care could be dramatically improved. As the OECD highlights, poor data quality risks complacency about health system accessibility, and health systems show varying capacities to address affordability questions. Promoting a more comprehensive approach to valuation - including devices, services, and medicines - would boost the efficiency and resilience of national health systems in the EU, it states, urging greater attention to epidemiology, severity of needs, and outcome-based data [24]. The central message from the OECD is that wiser deployment of health funds would allow better use without undermining access or quality of care. "A mix of policy levers could optimise spending by improving its value for money," it maintains.

Similarly, the OECD recommends "a transition from the traditional hospitalcentric approach to community-based and integrated care structures, putting the focus on person-centred care, chronic disease management capacity and, crucially, on prevention measures - the priority of health promotion as the precondition for effective - and indeed resilient - health systems" [25].

\section{Effective Use of Health Care Professionals}

Better organisation of health care also implies a review of the use of health care professionals. The Companion Report points out that organisation is the key in many cases to 


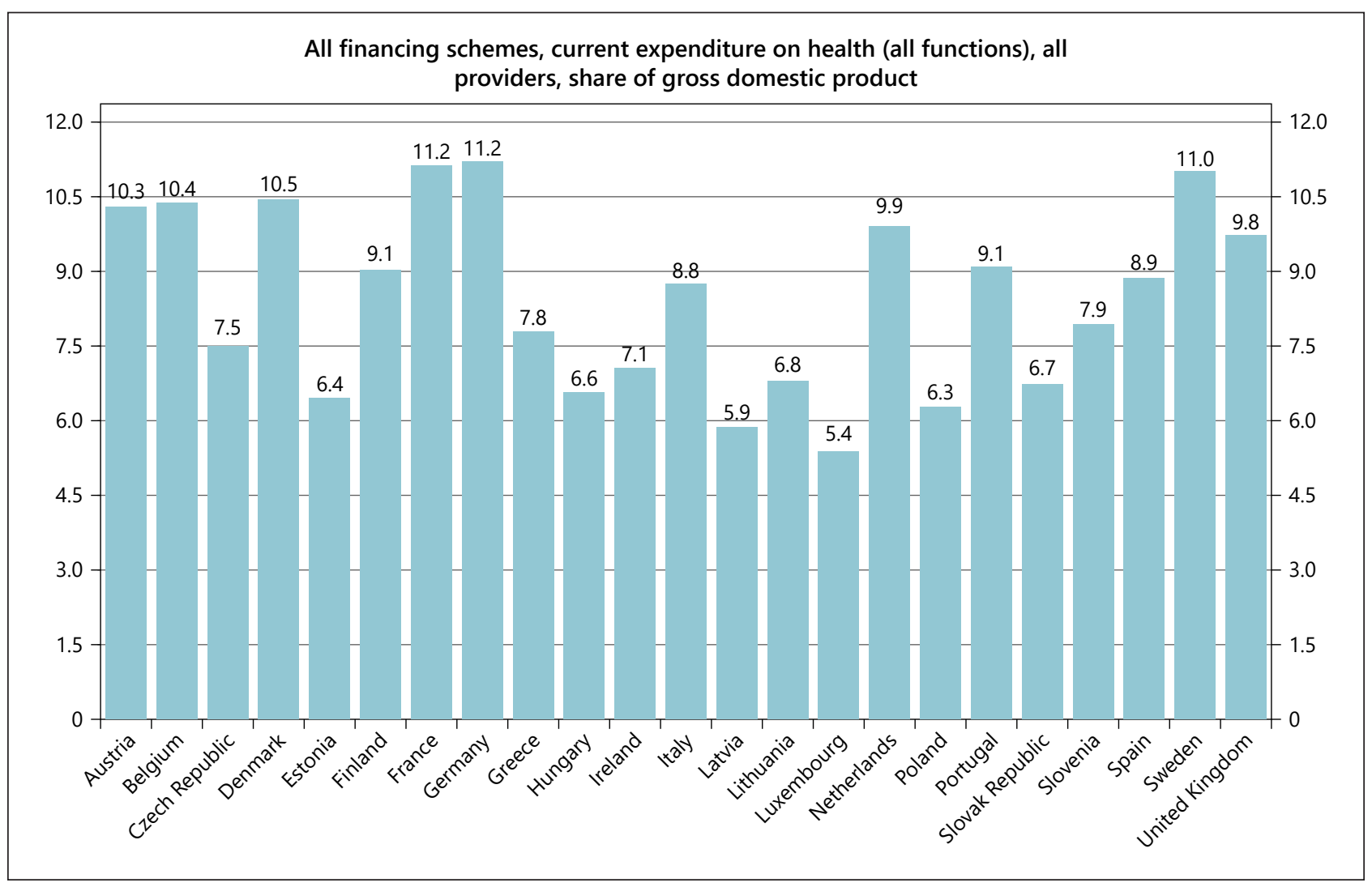

Fig. 13. Health expenditure in OECD countries, 2018.

meeting unmet needs, and the OECD urges equipping health workers with the right skills, and a new readiness to coordinate and cooperate in the face of changing care demands and digital technologies. Taking advantage of innovative technologies in better workforce planning can require overcoming traditional boundaries and hierarchies - but improves efficiency and strengthens sustainability and quality of care.

\section{Hesitations and Failures}

There are also some notable - and damaging - EU hesitations and failures to maximise the potential gains from developments in health technology assessment, digital health, mobilisation of genomics, advanced therapy medicinal products, national cancer plans, or crossborder health (Fig. 13). This is a phenomenon already remarked on in the literature. The health care system has not been involved in research and has tended to take for granted the progress of the technology of medicine. Nowadays, however, decisions about introduction and use of new options for prevention and treatment, based on research and development, are a major factor behind improvements in outcomes and cost-effectiveness, according to Jonsson and Sullivan [26]. However, they conclude, the health care system is not yet prepared for this new role. As the Companion Report diplomatically expresses it, "health technology assessment-related resources and expertise vary widely across the EU." Plans for greater coordination are blocked by profound differences among Member States.

The Commission approach to pricing care delivery is equally diplomatic, in deference to national sovereignty: "Attempts to simplify the rules and to better reflect the increased complexity of pricing and reimbursement procedures in EU countries have failed. Member 


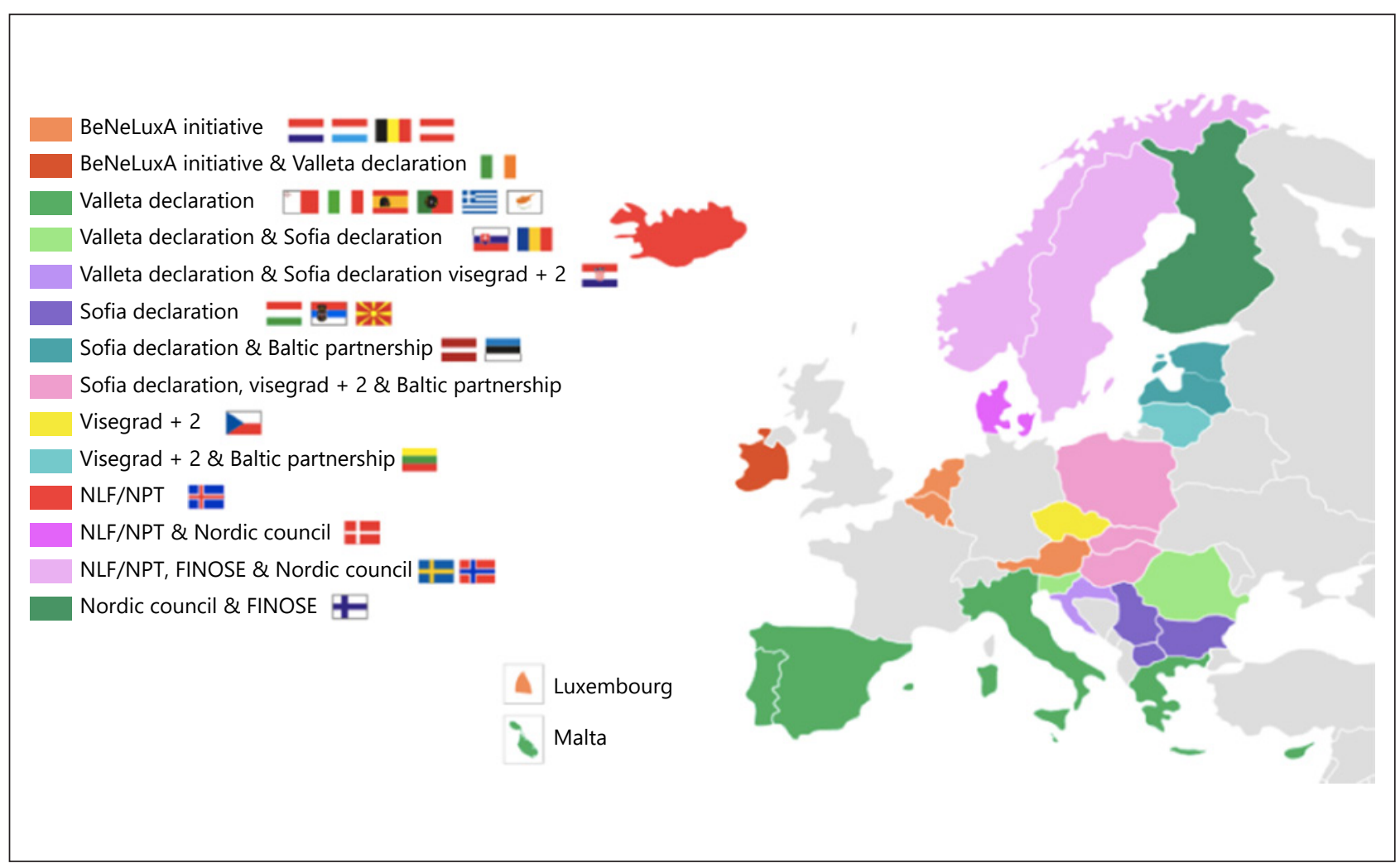

Fig. 14. Cross-border collaboration on market access, 2019. NLF, Nordic Pharmaceuticals Forum; NPT, Nordic Pricing and Reimbursement Group; FINOSE, HTA collaboration network between Fimea (Finland), NoMA (Norway), and TLV (Sweden). Source: European Commission [156].

States continue working with the Commission to find alternative ways to keep pace with pharmaceutical market developments and to ensure the transparency of pricing and reimbursement measures" [27].

Hesitancy over health care funding can have negative effects, suggests the European Health Coalition in comments on the OECD report. "EU Member States have underfinanced health systems which lead to lower-than-average life expectancy and poor health outcomes," it says - highlighting at the same time "the lack of comparable data to assess health system performance in terms of outcomes that matter for patients" [28].

Furthermore, the coalition indicates that the differing levels of access across and within countries spring from the level of public spending on health care, high rates of out-of-pocket expenditure in certain Member States, waiting lists, staffing shortages, underdeveloped primary care services, poor health literacy among vulnerable communities and lack of infrastructure in remote areas. As can be seen in Figure 14, out-of-pocket expenditure in EU countries ranges from nearly $50 \%$ of total health spending in less wealthy countries to less than $20 \%$ in countries with higher GDP per capita.

Nor does access to health care automatically mean that services are of high quality, adds the European Health Coalition, pointing to the significant variations in outcomes between or within Member States which cannot be explained solely by underlying risk factors or expenditure levels. It cites the variation in average delay between market authorisation and patient access for innovative medicines, with patients in Northern/ Western Europe averaging 100-200 days and patients in Southern/Eastern Europe averaging 600-1,000 days (Fig. 15). 


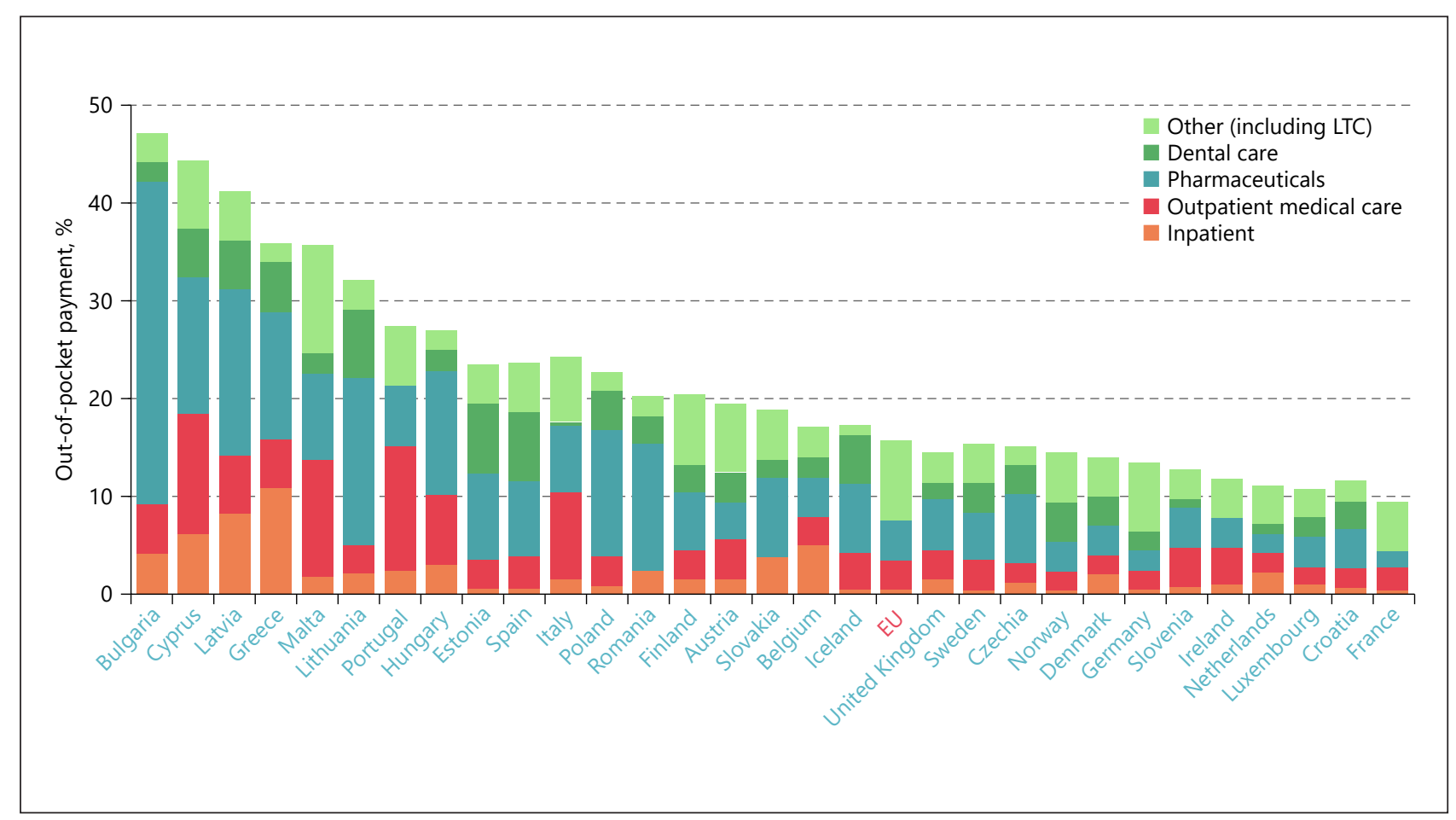

Fig. 15. Out-of-pocket expenditure in EU countries, 2019. LTC, long-term care.

\section{Paths to Fulfilment}

There Is a Perceptible Shift towards a Holistic Approach to Health, with a Greater

Emphasis on the Promotion of Healthy Lifestyles and Prevention

The deficiencies serve as a starting point for discussion of solutions - of paths to allow Europe to fulfil the potential that personalised health care promises. The direction of travel is plain: towards a holistic approach, greater emphasis on healthy lifestyles and prevention, in search of improved public health in coming years - with the prospect of earlier identification of disease, earlier treatment, and improved quality of life. More specific treatments informed by accurate biomarker testing - can reduce ineffective treatments and help avoid adverse events. More integrated planning and management will provide better returns on investment, and faster and fuller adoption of technology can bring new efficiencies.

The destination, a personalised health care delivery for all European citizens, may still be distant, and many questions need to be addressed about the cost-effectiveness of specific policies, the ability to influence individual behaviour, or how to distribute resources between policies - such as between better treatment with immunotherapy drugs and campaigns aimed at reducing smoking. More data are needed on the cost-effectiveness of respective policies, on which early-detection programmes bring real benefit, and on what programme designs promote cost-effectiveness. But the journey is already under way.

New personalised therapies and more sophisticated screening and diagnostic tools are now routinely emerging and becoming more widely available. There is increasing cooperation across health care silos. And there is a shift towards enhancing primary care and prevention (Fig. 16 confirms the continuing differences in spending on prevention but shows that some Member States now devote $4 \%$ or more of their budgets to its implementation). As Andriukaitis said: "Efforts for more health promotion and disease prevention are yielding 


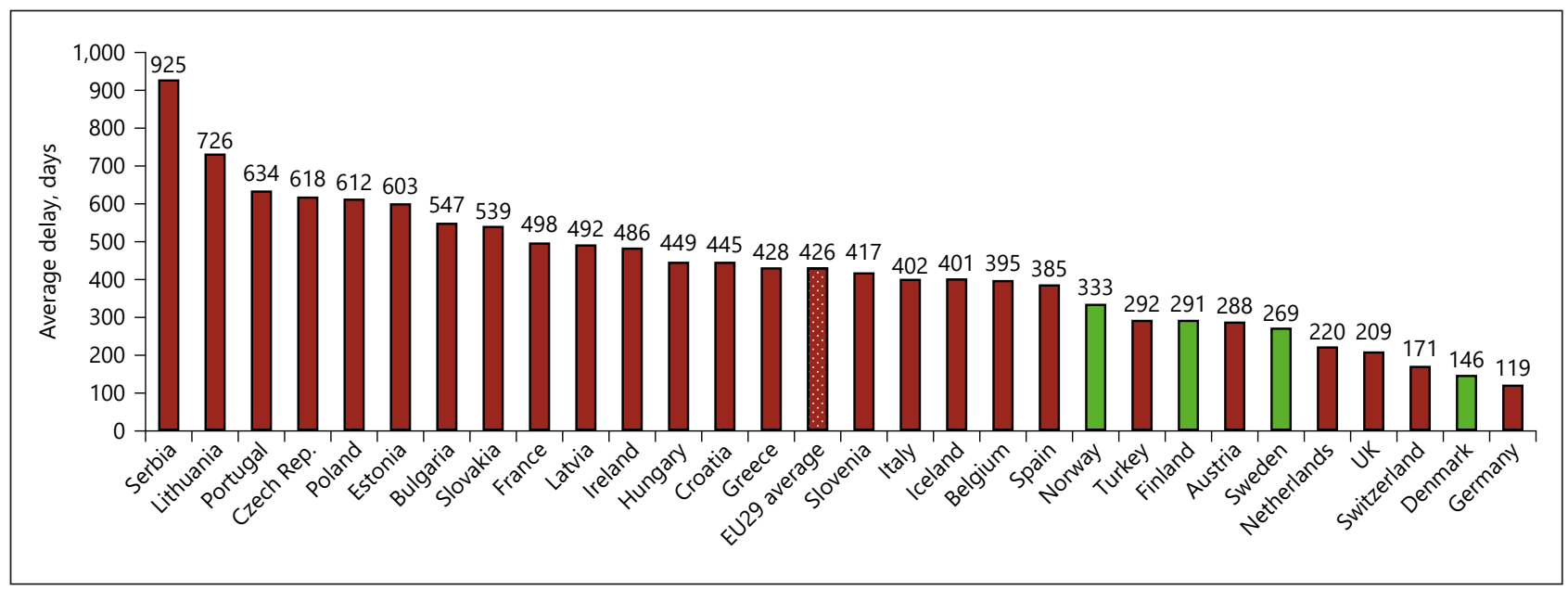

Fig. 16. Average time between marketing authorisation and patient access, 2018. Source: IQVIA [157].

positive results." Senior Commission officials want to increase the average 3\% of health care budgets that are allocated to prevention in Europe [29]. And again, it will be necessary to make evidence-based assessments of where programs are cost-effective and more costeffective than other uses of those resources. Personalised health care implies more alternatives and consequently more refined choices between alternative policies with different costs and outcomes.

\section{Those 3 i's - Incentives, Innovation, and Investment}

The shift in thinking that is increasingly influencing policymakers and policy, to the $3 \mathrm{i}$ 's of incentives, innovation, and investment - often linked - are more frequently being evoked. Allusions do not, of course, amount to action. But there are encouraging signs.

There is a growing recognition of the role that incentives can play in EU efforts to induce constructive change in national health systems. Mariya Gabriel, the new Commissioner for Research and Innovation, with a portfolio with a big impact on health care, is conscious of the power of incentives, and has spoken repeatedly of her ambition to revitalise research "through changed incentives and rewards systems and improved links to innovation ecosystems" [30]. The Companion Report also recognises how, in the first phase of medicines R\&D, "incentives play an important role," with development boosted through national and EU financial instruments and research infrastructures. Gabriel recognises the incentives created by intellectual property rights, tax and trade policy, and the increased role of the European Medicines Agency in scientific advice, parallel consultations, and accelerated assessment procedures [31], and the Commission is currently reviewing the incentives for developing orphan and paediatric medicinal products.

Much of the EU thinking on incentives in this area is linked to innovation. Health commissioner Kyriakides has spoken of the need to create "the right incentives for the development of antibiotics," and has advocated "the right incentives for innovation in areas of unmet needs" in relation to orphan drugs and paediatric medicines [32].

The OECD also noted how "national health policymakers have struggled" in providing incentives for pharmaceutical innovation [33], and Thierry Breton, the new Commissioner for industry, favours "a sustainable human-centric approach to innovation," warning against "regulatory burdens on innovation and business development" [34]. Finland, the Health Council president in the second half of 2019, emphasised the importance of realigning the 
innovation model "to ensure that it delivers the right innovations, at the right prices and defines appropriate rewards" [35].

Innovation is heavily dependent not just on incentives, but also on investment. Gabriel's mission is to "ensure sufficient investment flows to disruptive research and breakthrough innovations" [36]. Gabriel wants to see research and innovation "deliver a maximum contribution to our common objectives," with Member States "better coordinating their investments to provide scientists with the resources they need to produce new knowledge" [37].

\section{Thinking of Fulfilment - Declarations of Intent}

Grounds for Optimism Can Be Found in the Evolution of Thinking among Policymakers, the Priorities They Reveal, and the New Readiness to Entertain New Ways of Working

The new Commission President has a vision of Europe taking a global lead, and has encouraged her team to "be decisive and ambitious on the big issues of our time that are shaping the future of our society, economy and planet" [38]. Key members of her team share her enthusiasm. Breton profiles himself as a champion of change, a defender of European innovation and research capacity [39]. Health commissioner Kyriakides promises to help meet "the need for sustainable and effective health systems, supporting health professionals, investing in new technologies, and promoting healthy and sustainable lifestyles" [40]. She has firmly endorsed the concept that "health - in its universal sense - requires a holistic, wholeof-society approach." And she subscribes to the idea of innovation, and "the role that science and new technologies play in developing new solutions." To achieve this, she knows that regulatory frameworks must remain up-to-date and citizen-centred [41].

This new European configuration recognises the merits of innovation and of the links with incentives and investment. Von der Leyen wants change that "drives Europe's innovation and competitiveness," that builds on "our world-leading science, research and innovation capacity," and that benefits from "investment flows to disruptive research and breakthrough innovations" [42]. Gabriel is proud of her mission in which "research and innovation are recognised as a key factor for European competitiveness on a global scale ..." and that requires the right research infrastructures both for frontier research and to produce innovation [43]. Kyriakides is ready to work with the Commissioners for industry and research "together with public authorities, industry and other stakeholders, to encourage the development of new business models fostering innovation" [44]. The 2019 Annual Growth Survey also insisted that investing in innovation is vital for successful health care [45]. Finland's Presidency highlighted at the June EU Health Council that "the innovation model needs to be realigned to ensure that it delivers the right innovations, at the right prices and defines appropriate rewards."

\section{Innovation and Investment - and Incentives}

The Attention to Innovation and Investment - and Incentives - Is Seen as Particularly

Relevant to the Provision of the Medicines That an Upgraded Vision of Health Care

Requires

Health care is changing, and the OECD notes that this is "partly due to technology advances that allow a more targeted approach in therapies." With wider awareness of the opportunities this can offer, momentum is gathering for breaking down silos between different areas of health budgeting, opening up the possibilities for better choices in therapy. In this changing environment, ideas are crystallizing on how to do more with available resources, underlining 


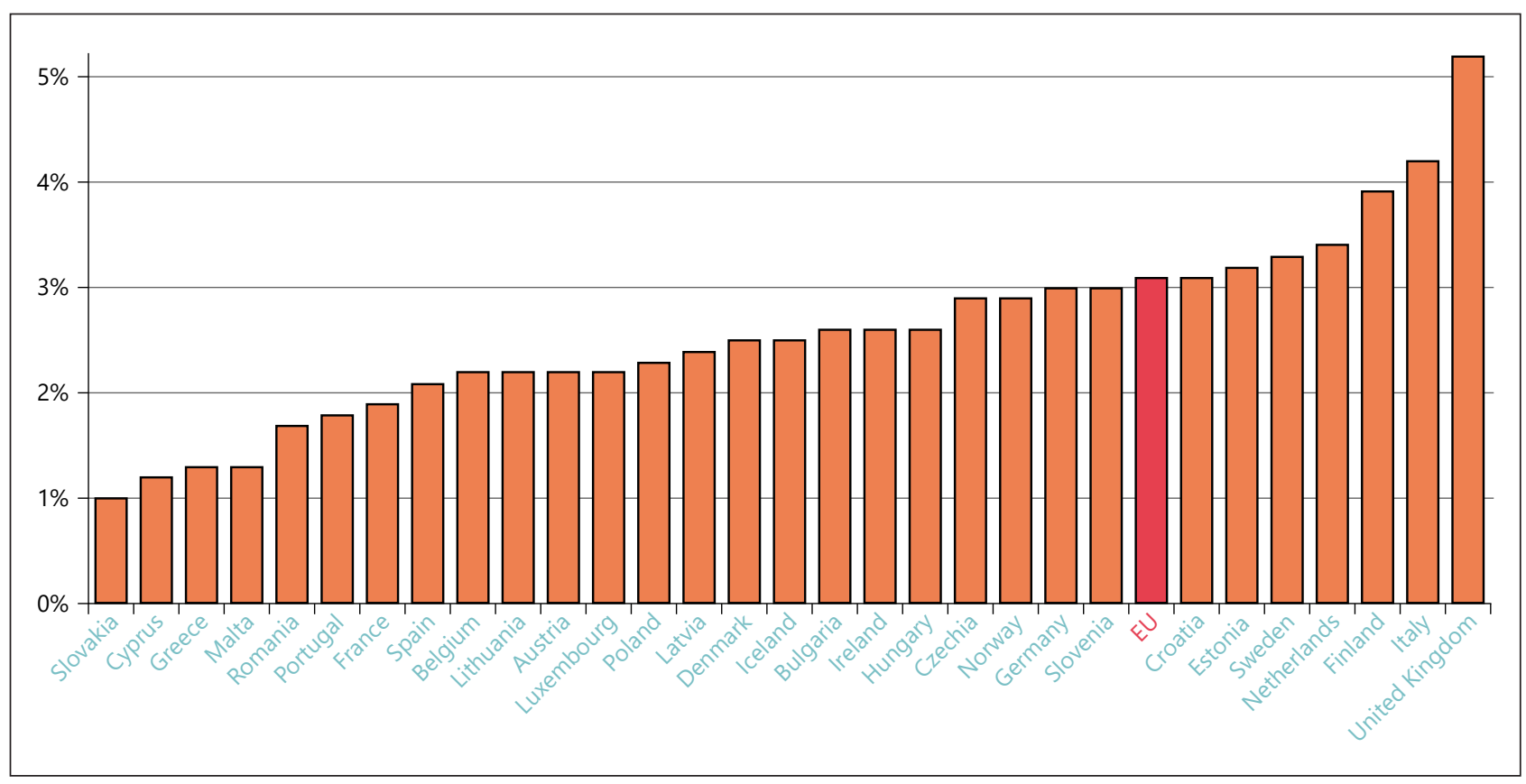

Fig. 17. Expenditure devoted to prevention across EU, 2019. Source: European Commission [156].

the need for aligning incentives across care settings to avoid segmented approaches to budgeting for pharmaceuticals [46].

Future-oriented therapy development is seen as vital in this context. Von der Leyen has told Kyriakides to support the European pharmaceutical industry to ensure that it remains an innovator and world leader. Kyriakides has undertaken to ensure "a steady stream of affordable medicines" - which means "we need to invest and encourage innovation" so that the European medicines industry remains an innovative world leader. This requires everyone "to work across all policy areas ... to have a holistic pharmaceutical strategy." She has also promised to "consider measures to provide the right incentives for innovation in areas of unmet needs" - particularly in respect of the ongoing review of the EU's orphan and paediatric legislation. And since "supporting medical research involves turning the EU pharmaceutical and medical technologies' value chain into a needs-driven, innovative, seamless and forward-looking system," she says she will "work on aligning research priorities with the needs of health systems while involving regulators, academia, health care professionals and health care providers and payers" [47].

As the OECD recognises, the advent of new, high-cost medicines targeting small populations calls for a redesign of existing payment models, in particular with a focus on instalment plans to smoothe out upfront purchasing costs and pay-for-performance approaches to ensure high-value care is provided. It suggests that expertise can be pooled at the EU level. The OECD report speaks of "setting up appropriate incentives for pharmaceutical research and innovation" and notes the continuing search by national health policymakers for balance "between ensuring accessibility to medicines, providing incentives for pharmaceutical innovation and ensuring the fiscal sustainability of health spending" [48].

Kyriakides' plan is to work closely with all the stakeholders and with industry and the Member States, "because we need to look at the pricing mechanisms of the Member States and also how medicines are reimbursed" [49]. Finland during its recent presidency instigated fresh debate on European pharmaceutical policy, with a focus on improved access to medi- 


\begin{tabular}{|c|c|c|}
\hline Sustainable innovation & $\begin{array}{l}\text { Ensuring access and } \\
\text { affordability while } \\
\text { addressing shortages, unmet } \\
\text { needs }\end{array}$ & $\begin{array}{l}\text { Ensuring security and } \\
\text { oversight of the global } \\
\text { manufacturing supply chain }\end{array}$ \\
\hline \multicolumn{3}{|c|}{$\begin{array}{l}\text { Need to ensure flexibility, forward thinking, sustainability of the network, traceability, trust in } \\
\text { the system and reduce regulatory burden (across the board) }\end{array}$} \\
\hline $\begin{array}{l}\text { Action plan on } \\
\text { pharmaceuticals in the } \\
\text { environment }\end{array}$ & $\begin{array}{l}\text { Reinforce market launch } \\
\text { for CAPs }\end{array}$ & $\begin{array}{l}\text { (API) Action plan to enhance } \\
\text { oversight of the global } \\
\text { manufacturing and supply chain }\end{array}$ \\
\hline $\begin{array}{l}\text { Joint commission-EMA } \\
\text { action plan to improve the } \\
\text { regulatory environment for } \\
\text { ATMPs }\end{array}$ & $\begin{array}{l}\text { Reinforce obligation to } \\
\text { supply and addressing } \\
\text { shortages, measures on } \\
\text { parallel trade }\end{array}$ & $\begin{array}{l}\text { Monitor and ensure the } \\
\text { supply chain integrity }\end{array}$ \\
\hline $\begin{array}{l}\text { Better regulation and } \\
\text { common understanding on } \\
\text { innovative "borderline" } \\
\text { products }\end{array}$ & $\begin{array}{l}\text { Supporting not-for-profit } \\
\text { organisations and academia } \\
\text { in drug repurposing }\end{array}$ & $\begin{array}{l}\text { Reduce dependency on APIs } \\
\text { from third countries } \\
\text { especially for "strategic" } \\
\text { medicines and vaccines }\end{array}$ \\
\hline $\begin{array}{l}\text { Product information and } \\
\text { digitalisation: e-leaflet }\end{array}$ & $\begin{array}{l}\text { Evaluation of orphan \& } \\
\text { paediatrics legislation }\end{array}$ & Quality of active substances \\
\hline $\begin{array}{l}\text { Discussing the paradigm of } \\
\text { assessment, authorisation and } \\
\text { pharmacovigilance in light of } \\
\text { the possible use of real-world } \\
\text { evidence, Al etc. }\end{array}$ & AMR action plan & \\
\hline $\begin{array}{l}\text { Addressing ethical, } \\
\text { proprietary and security } \\
\text { concerns incl. ownership and } \\
\text { access to data and the } \\
\text { algorithms behind Al } \\
\text { applications }\end{array}$ & $\begin{array}{l}\text { Uptake of generics and } \\
\text { biosimilars }\end{array}$ & \\
\hline $\begin{array}{l}\text { Mapping and acquiring } \\
\text { expertise to deal with new } \\
\text { innovative products in a } \\
\text { digitised environment in } \\
\text { combination with medical } \\
\text { devices }\end{array}$ & Medical use of cannabis & \\
\hline Variations & & \\
\hline
\end{tabular}

Fig. 18. Pharmaceutical Committee programme for the next 5 years, 2019. CAPs, centrally authorized products; EMA, European Medicines Agency; ATMPs, advanced therapy medicinal products; APIs, active pharmaceutical ingredients; AI, artificial intelligence; AMR, antimicrobial resistance. Source: Pharmaceutical Committee [158].

cines. And as the OECD study remarks: "The innovation model needs to be realigned to ensure that it delivers the right innovations, at the right prices and defines appropriate rewards" [50]. "Acting at the appropriate health system level will enable EU health systems to make progress towards the dual objectives of promoting patient access to high-value innovation while ensuring sustainable health systems," says the OECD, which points to the merits of building up Member State capacity to appraise the value of medical technologies in a more comprehensive manner, and stepping up efforts to share experiences and pool expertise on pricing and procurement methods [51]. Kyriakides sees health technology assessment as "extremely important," not least because it allows innovation. Conscious of reluctance among 
some Member States, she says "We need to pool resources. We need to have common standards in order to protect patients" [52].

Meanwhile, the EU's own group of senior advisers on medicines, the Pharmaceutical Committee, has identified an ambitious programme (Fig. 17) focused on "sustainable innovation" - ranging from improving the regulatory environment for advanced therapy medicinal products to developing expertise to deal with new innovative products [53].

\section{Translating Innovation into Health Care Systems}

With both the new European Commission hierarchy and the EU research programme Horizon Europe placing new emphasis on cancer, many further opportunities are likely to emerge for widening understanding both on the leading-edge therapies in this crucial field and on the importance of embedding therapeutic advance in a coherent and comprehensive health care context.

A constructive tone was established by von der Leyen's instructions to Kyriakides “to support Member States to improve cancer prevention and care, with a European Beating Cancer plan covering prevention, diagnosis, treatment, life as a cancer survivor and palliative care, and with close links to the research mission on cancer in the future Horizon Europe programme" [54]. Kyriakides has also shown determination to improve screening. She is confident that "by joining forces, pooling knowledge, data, resources and infrastructure, we can make a difference. We can beat cancer." In her view, prevention can help to bring down the costs of cancer, reduce pressure on health and social systems, and contribute to economic growth ... [55]. She also sees artificial intelligence as a promising support (EU expectations in 2019 are displayed in Fig. 18). And in the area of treatment, she sees a rich pipeline of cancer medicines, especially for adult cancers, including breakthrough gene therapies and personalised treatments.

The consultation on cancer launched by the Commission in February sees promise in an integrated approach making best use of the opportunities for personalised care. Important new medicines will emerge from the 1,000 clinical trials now under way in immune-oncology, and new thinking will be required for making therapeutic decisions and for providing the right incentives for the development of new cancer medicines.

\section{Antimicrobial Resistance and the Development of Medicines}

\section{The Field of Antimicrobial Resistance Offers a Further Area of Overlap with the}

Involvement in the Development of Medicines

Particularly in respect of antimicrobial resistance, Kyriakides recognises the challenges: "We need to create the right incentives for the development of antibiotics ... we need to help industry, through innovation, to come up with new antimicrobials ... Wealso need to encourage as much as possible the development of new vaccines" [56]. She also sees the wider impact of successful European activity in this challenge. "Part of this is encouraging industry to come forward through innovation with new antibiotics ... We need to help industry, through innovation, to come up with new antimicrobials."

The new Commission is also giving renewed emphasis to research as part of its commitment to innovation, and this has been widely reflected in public pronouncements over recent months - frequently with direct reference to medicines and health care, as indicated above, but also for the broader range of scientific and technological research which also critically influences the progress of health care. 
As von der Leyen said, the best investment in the EU's future is in innovators and researchers as the key to competitiveness: "Our world-leading science, research and innovation capacity can help us find European solutions to the most pressing global issues." And Gabriel's specific responsibilities include "swift agreement on and full implementation of the future Horizon Europe programme," and ensuring "investment flows to disruptive research and breakthrough innovations." She insists on better support to innovators to bring their ideas to the market [57] and on Member States coordinating their investments to provide scientists with the resources that they need [58].

\section{Discussion: Future-Proofing the Policy Area}

The way ahead for policy, the Commission insists, must be to base decisions on evidence and on science. This also opens up prospects for adapting health care policy in light of genuine needs and objective observation, rather than simply relying on tradition or prejudice.

Again, this policy comes from the top. Von der Leyen said in her instructions to her team that "proposals must be evidence based, widely consulted upon and subject to an impact assessment" [59]. Gabriel elaborated on the theme: "Science underpins and informs most EU policy areas because it delivers new technologies, creates space for social innovation and experimentation and provides new knowledge and evidence-base for policy-making ..." [60]. Specifically in the field of health care, Kyriakides endorsed the view. "We need to base policy decisions on science ... We need to fight any source of misinformation which impacts negatively on where we know that there is a solid science." Vytenis Andriukaitis also urged "a credible evidence-based approach" [61]. Von der Leyen specifically gave Kyriakides a mission "to prioritise communication on vaccination, explaining the benefits and combating the myths, misconceptions and scepticism that surround the issue" [62]. And Kyriakides is ready to engage in that task. "We have the science which shows us that it is important that we use vaccines" [63]. As the EU/OECD says, "vaccine hesitancy, a major public health threat all across Europe, can be tackled by improving health literacy and countering disinformation head-on, with health workers actively involved ..." [64].

\section{Digitalisation}

Enthusiasm for developing a coherent and forward-digitalisation process for health is reflected in the forward planning of the new commission as well as in the conclusions of the state of health.

The Commission's February 2020 Strategy for Data explicitly and amply recognises the potential for health. "Personalised medicine will better respond to the patients' needs by enabling doctors to take data-enabled decisions. This will make it possible to tailor the right therapeutic strategy to the needs of the right person at the right time, and/or to determine the predisposition to disease and/or to deliver timely and targeted prevention," it says [65].

Digital transition, says von der Leyen, "is helping us to redesign our economy, make our industry more competitive and find new solutions to societal challenges" [66]. As Gabriel puts it, "digitalisation and new technologies are revolutionising the way we live and work" [67]. Breton aims at turning Europe into a digital, technological and industrial leader through a wide process of cooperation [68]. And Kyriakides' focus is on digitalisation's scope for keeping citizens healthy. "Digitalisation can be a game changer - it can bring concrete benefits to patients and health care professionals and has the potential to provide cost-effective highquality health care whilst reducing inequalities" [69].

The promised European Health Data Space is destined to promote responsible but effective data exchange and support research, following a direct instruction from von der Leyen, who sees 
Fig. 19. Digital health opportunities in Europe, 2019. GDP, gross domestic product; GPs, gross products; ICT, information and communication technology. Source: European Commission [159].

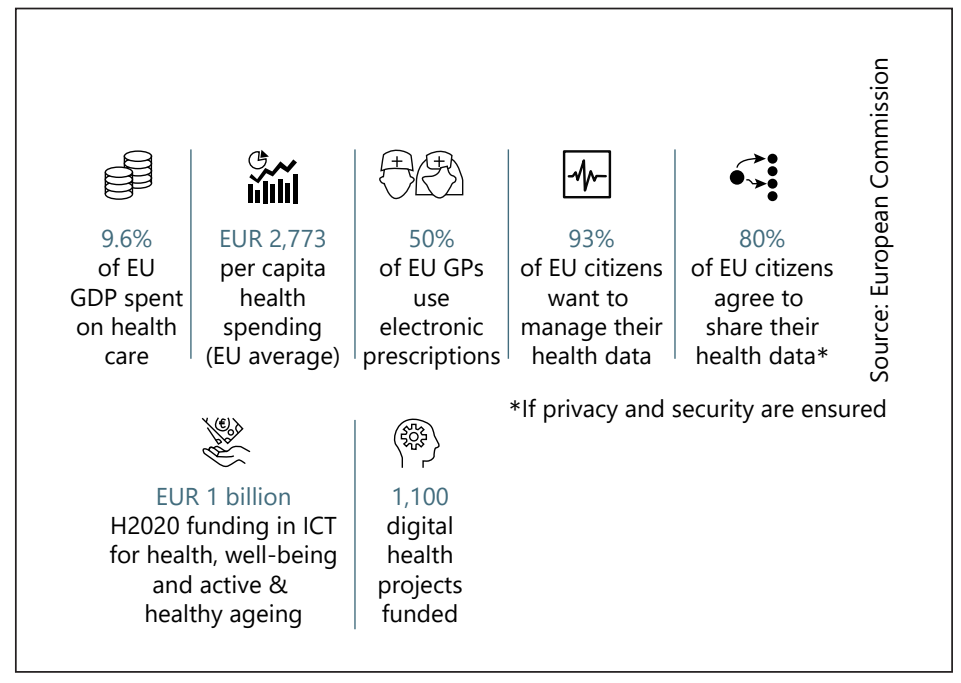

e-health as an avenue to provide high-quality health care and reduce inequalities. She told Kyriakides to create it to "promote health-data exchange and support research on new preventive strategies, as well as on treatments, medicines, medical devices and outcomes" [70]. Member States now exchange e-prescriptions and patient summaries through the eHealth Digital Service Infrastructure, and the Commission has adopted a European Electronic Health Record Exchange Format to improve data sharing and empower citizens' access to their own health records [71].

The OECD has noted that the regulatory framework and the technical assessment tools used by health authorities should be ready to deal with the growing bundling and interaction of pharmaceuticals, medical devices and software emerging from digital transformation's impetus for combination products and companion diagnostics. Flexible reimbursement systems should come to be seen as part of a broader, comprehensive health promotion and disease prevention strategy, it argues [72]. And von der Leyen has told Gabriel to "focus on digital literacy and education to close the digital skills gap" [73]. Kyriakides agrees that health data are critically important to achieve the transformation [74]. The current gulfs in health literacy within Europe's population are highlighted in Figures 19 and 20.

The EU Health Coalition sees an important EU role in supporting strategic investments and setting standards and a common governance framework for health data and has urged the setting up of a European Health Data Institute to drive the digitalisation of European health systems. It has also recommended educational initiatives to ensure that people have equal opportunities to utilise digital tools and to better manage their health [75].

\section{Stimulating Industry and Entrepreneurship}

The outlook for industry and entrepreneurship in general is improved by the focus that the new commission has placed upon it, in addition to the strong support demonstrated for innovation per se.

Europe's industrial future deserves "a comprehensive long-term strategy," said von der Leyen. She told Breton: "This should cover all aspects that affect industry and its competitiveness" and should ensure that the EU intellectual property regime is coherent, fit for the digital age and supports competitiveness [76]. Breton is aiming at a regulatory framework fit for the digital age, and at the personal dimension of industry, ensuring individual workers have the skills they need, and that smaller firms are assisted in tackling administrative burdens and finding the workforce they need [77]. 


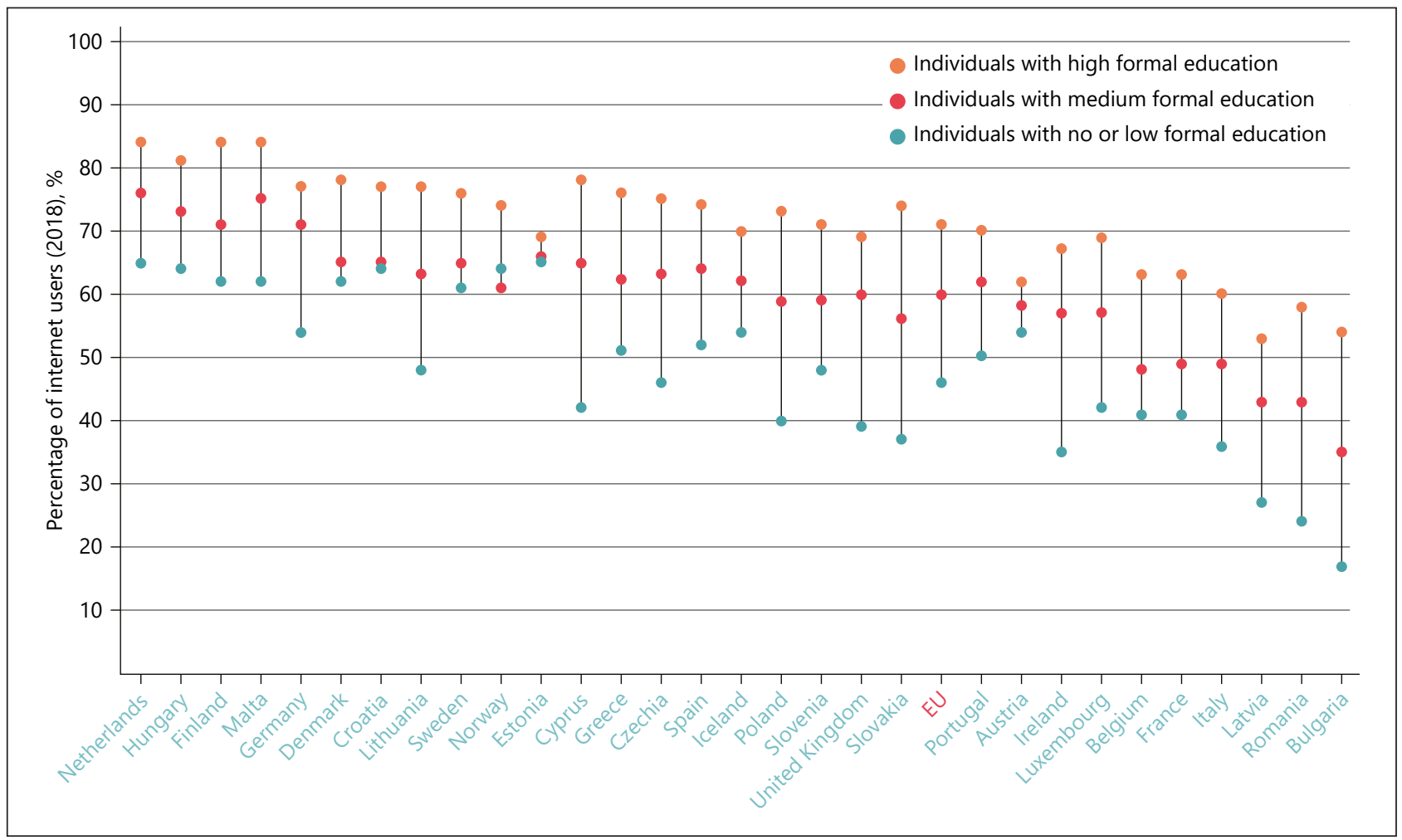

Fig. 20. Seeking health information online varies strongly by education, 2019.

\section{Tackling the Challenges: Action to Take}

Influenced by the many difficult challenges faced by health care in Europe today, and in light of the opportunities offered by science, research, technology, and the mobilisation of citizens themselves, policy makers are acknowledging the need for readjustments - and even for radical rethinking - of their approaches to health and health care. They are starting to reorganise, to seek synergies in cooperation and infrastructure, and to create more appropriate contexts for effective health services. This spirit of openness holds out the prospect of permitting more focused thinking on how the benefits of personalised health care and personalised medicine can be integrated into revised health care systems.

The emphasis in this new openness is both on making better use of resources to improve health, and on integration and development of new and better forms of cooperation across the many sectors and stakeholders involved. Kyriakides spoke about "creating the right conditions and developing cooperation on tools and instruments for national policy making" and promised: "We will support the industry and our Member States in constantly improving the quality and sustainability of their health systems through improved information sharing, expertise and the exchange of best practices." And she added: "I do see better coordination necessary" [78].

Integration is catching on. The European Semester process is increasingly issuing detailed recommendations to Member States in the planning of health care, with a focus on cost-effectiveness. The 2019 Annual Growth Survey stated that "Member States need to increase costeffectiveness by ... improving the integration of health care at the primary, specialised outpatient and hospital care levels, with more attention to prevention" [79]. The OECD sees Member States shifting towards a concept of integrated care, with related reallocation of tasks among health workers that improve patient satisfaction and clinical outcomes [80]. During 2019 the EU's Social Protection Committee and the Council Working Party on Public Health at Senior Level 
concluded that Member States are reforming their health systems to strengthen the delivery of primary and integrated care [81]. Gabriel has promised that Horizon Europe will be more proactive in seeking synergies with other EU programmes, because resolving the challenges we face "requires more cooperation across infrastructures and across disciplines." It is central to von der Leyen's strategy too that "we need to speak and listen more to one another" [82].

\section{Member States in Action and Increased Cooperation}

National authorities are already moving towards reform, with some common approaches on aspects such as the shift from hospital to primary care, or closer integration of services, or better performance measurement, or wider use of digital technologies, as well as increasingly sharing expertise [83-94].

The value of exchanges is being demonstrated. Finland has gained from neighbouring countries' feedback on health system performance assessment, and Cyprus benefited from the experience of 9 other Member States in planning its health reforms, while experts from Belgium, France, Ireland and the UK advised Sweden on strengthening health promotion and disease prevention.

Austria is improving its coordination across the federal government, social health insurance funds and regional governments - and consolidating its health insurance funds, while Finland plans to re-organise its health and social care services and funding. Belgium has strengthened primary care and promoted integrated care for chronic conditions, and is now encouraging multidisciplinary teamwork. Denmark has cut hospitalisation by easing access to primary care and deploying e-health more widely. Hungary is shifting care to the outpatient sector, and Italy is running regional pilot studies on new service delivery models with the accent on integration.

Luxembourg is strengthening primary care and promoting day surgeries and multidisciplinary care competence networks. Norway has shifted care to the community, with strengthened local capacity reducing delayed hospital discharges and readmissions. Czechia has cut mortality through reducing risk factors and concentrating care in specialised centres using new treatments, and Slovenia has improved survival through more effective therapies and population-based screening programmes.

In terms of medicine use specifically, reforms are also under way. Denmark has put in place measures to ensure timely access to new medicines, while at the same time controlling the growth of pharmaceutical costs, including through expansion of a single purchaser for pharmaceuticals dispensed in hospitals. In Malta, access to new medicines has been improved by the increased use of managed entry agreements, the provision of biosimilars and the embedding of clinical pathways, along with protocols for the evaluation of new medicines. The Netherlands is trialling long-term contracts that focus on innovation, appropriate care, and eliminating waste, with a view to transforming health technology acquisition from a focus on volumes and prices to one that espouses quality and value. Estonia has targeted investments in health technology assessment, primary health care, biobanking and e-health, with a view to increasing the resilience of the health system.

Germany, France, Belgium, Spain, Portugal, and Slovenia are already looking at how they might make use of their upcoming EU Council presidencies in some of these crucial areas.

\section{A Checklist of Progress by Way of Conclusion}

Creating a structure and a climate in which personalised medicine can realise its potential is a long-term exercise, but an approach has been designed that breaks down the challenges indicated above across the many factors and stakeholder groups. The following Table 3 is a 
Table 3. Building block

\begin{tabular}{|c|c|c|c|}
\hline Enabler & Element description & Element example & Country \\
\hline \multicolumn{4}{|c|}{$\begin{array}{l}\text { Category: planning and enablers } \\
\text { 1. Strategy and Investment }\end{array}$} \\
\hline Vision & $\begin{array}{l}\text { - National, regional, and local stakeholders } \\
\text { have a strong understanding of personalised } \\
\text { health care and a clear vision for its short-, } \\
\text { medium-, and long-term implementation } \\
\text { - This vision is cocreated with and } \\
\text { communicated to all relevant stakeholders } \\
\text { - It covers the full patient journey (e.g., from } \\
\text { prevention and health promotion to end-of-life } \\
\text { and palliative care) and considers all aspects } \\
\text { of personalised health care (e.g., technological, } \\
\text { geographical, financial), with the aim to } \\
\text { improve patient and health system outcomes }\end{array}$ & $\begin{array}{l}\text { Central NHS leadership for digital } \\
\text { health and health data [83] } \\
\text { - Central vision and leadership of digital } \\
\text { health initiatives is coordinated via the } \\
\text { NHS } \\
\text { - Seven data/digital innovation hubs have } \\
\text { been selected by HDRUK across the UK to } \\
\text { improve data curation and use to boost } \\
\text { patient care, improve outcomes, and } \\
\text { deliver fair value on the use of data } \\
\text { - The hubs each focus on either a specific } \\
\text { disease area or data type, e.g. oncology, } \\
\text { ophthalmology, RWD, merging vision and } \\
\text { expertise to deliver enhanced data sets } \\
\text { that will drive research, innovation, and } \\
\text { improved outcomes }\end{array}$ & UK \\
\hline Leadership & $\begin{array}{l}\text { - Decision-makers at all levels of the health } \\
\text { system are equipped with the right knowledge } \\
\text { and skills to drive value-based personalised } \\
\text { health care while empowering implementation } \\
\text { actors } \\
\text { - The right stakeholders are empowered to } \\
\text { make decisions relating to personalised health } \\
\text { care, building trust in their decisions and in } \\
\text { the value of personalised health care }\end{array}$ & $\begin{array}{l}\text { Estonian EU presidency in } \mathbf{2 0 1 7} \text { [84] } \\
\text { - Digital health was a priority of the } \\
\text { Estonia presidency of the EU Council from } \\
\text { July to December } 2017 \\
\text { - The Estonian Ministry of Social Affairs } \\
\text { and ECH Alliance launched the "Digital } \\
\text { Health Society Declaration": a call for } \\
\text { action to achieve the digital } \\
\text { transformation of health care systems }\end{array}$ & Estonia \\
\hline $\begin{array}{l}\text { Implementation } \\
\text { strategy }\end{array}$ & $\begin{array}{l}\text { - An explicit and action-oriented strategy has } \\
\text { been defined to implement or build } \\
\text { personalised health care but remains flexible } \\
\text { enough to reflect the dynamic environment of } \\
\text { health care } \\
\text { - Clear timelines are based on the current } \\
\text { state of the health system, in order to follow } \\
\text { ambitious but pragmatic steps that reflect the } \\
\text { maturity of different countries or regions } \\
\text { - Collaborative governance and change } \\
\text { management are at the core of the strategy } \\
\text { - Potential challenges and disparities that } \\
\text { could lead to uneven implementation of or } \\
\text { access to personalised health care are } \\
\text { systematically considered, to ensure equitable } \\
\text { health }\end{array}$ & $\begin{array}{l}\text { Australian Implementation Plan for the } \\
\text { National Health Genomics Policy } \\
\text { Framework [85] } \\
\text { - The Australian government developed a } \\
\text { National Health Genomics Policy strategy } \\
\text { - This is supplemented with an } \\
\text { implementation plan that includes } \\
\text { prioritised actions, roles, time frames for } \\
\text { completion and lead responsibilities }\end{array}$ & Australia \\
\hline
\end{tabular}


Table 3 (continued)

\begin{tabular}{|c|c|c|c|}
\hline Enabler & Element description & Element example & Country \\
\hline Funding & $\begin{array}{l}\text { - Short- and long-term government } \\
\text { investment is in place for personalised health } \\
\text { care, covering the full spectrum of health (i.e., } \\
\text { from prevention to end-of-life care), health } \\
\text { services, health products and data } \\
\text { - Investment is targeted towards areas that } \\
\text { deliver proven value or transformative } \\
\text { innovation (e.g., genomics), de-commissioning } \\
\text { obsolete technologies and leveraging } \\
\text { efficiencies (e.g., generic headroom) to ensure } \\
\text { sustainable funding } \\
\text { - Some funding is specifically dedicated to } \\
\text { limit disparities (e.g., for underserved } \\
\text { patients) }\end{array}$ & $\begin{array}{l}\text { Investments in Singaporean IT network } \\
\text { [86] } \\
\text { - Singapore has made significant } \\
\text { investments into IT/cloud infrastructure } \\
\text { and computational capacity } \\
\text { - Government spending amounts to SGD } \\
15 \text { million annually for EHR capacity } \\
\text { maintenance and expansion } \\
\text { - A new cloud-based health care } \\
\text { information model, hCloud, is being } \\
\text { launched, costing SGD } 37 \text { million in the } \\
\text { first } 10 \text { years } \\
\text { - The government are testing the } \\
\text { commercialisation of health data } \\
\text { *** } \\
\text { Australian Genomics Health Futures } \\
\text { Mission [87] } \\
\text { - There has been significant funding and } \\
\text { investment to improve genomic medicine } \\
\text { in Australia, amounting to AUD } 500 \text { million } \\
\text { for the 10-year initiative }\end{array}$ & $\begin{array}{l}\text { Singapore } \\
\text { A** } \\
\text { Australia }\end{array}$ \\
\hline
\end{tabular}

Communication - A simple, human communication strategy around personalised health care helps to make the case for this and emphasise the benefits to patients and society, fostering buy-in and involvement

- This clarifies the scope of personalised health care and illustrates it into easy-tounderstand components

- This raises awareness and expectations around how to conduct and be involved in personalised health care at a societal level, connecting the dots between strategy and implementation

\section{Data Saves Lives by the European \\ Patients Forum [88] \\ - Data Saves Lives is an initiative, hosted by the EPF secretariat, to address the challenges and opportunities relating to health data \\ - The core of the initiative is the development of an informative web platform that will provide lay-language information for patients and citizens who need neutral, understandable and comprehensive information on the topic of health data}

\section{Patient awareness and empowerment}

\section{Health literacy \\ - People are empowered to understand and} act with regard to their own health, partaking in shared decision-making based on appropriate levels of information

- Patients and patient associations understand and advocate the scope of personalised health care and their roles within it, and are involved broadly and early in formal and informal processes

- Awareness and education campaigns are in place to cover specific personalised health care topics (e.g., prevention and lifestyle, screening and prevention, role of digital health, ethical aspects of genomics)
Health Literacy Europe and National Alliance for Health Literacy [89]

- The Health Literacy Europe and National Alliance for Health Literacy combine 60 organisations ranging across patients, providers, insurers, academia and industry - This network aims to advance European health literacy and education on personalised care

$* * *$

Citizen referenda in Switzerland

- Citizens can call constitutional and legislative referendums

- They are consulted on proposed laws several times a year and are accustomed to partaking in the dialogue and having a say 
Horgan et al.: Propelling Health Care into the Twenties

Table 3 (continued)

\begin{tabular}{|c|c|c|c|}
\hline Enabler & Element description & Element example & Country \\
\hline $\begin{array}{l}\text { Education and } \\
\text { skills }\end{array}$ & $\begin{array}{l}\text { - People - including patients and patient } \\
\text { associations - are equipped with the } \\
\text { knowledge, skills and tools to cocreate the } \\
\text { personalised health care ecosystem } \\
\text { - Through training programmes, courses, } \\
\text { interactions with HCPs, tutorials, and other } \\
\text { means, they can collaborate with other } \\
\text { stakeholders to define what works for them } \\
\text { (e.g., using digital vs. non-digital means, opting } \\
\text { in vs. opting out) } \\
\text { - They are empowered on topics including but } \\
\text { not limited to data donation and sharing, } \\
\text { informed decision-making and/or providing } \\
\text { consent appropriately } \\
\text { - Patient representatives and associations are } \\
\text { involved broadly and early in formal processes } \\
\text { and decision-making for health care (e.g., } \\
\text { regulatory, HTA), as well as informal } \\
\text { consultations }\end{array}$ & $\begin{array}{l}\text { Widening Digital Participation } \\
\text { programme [90] } \\
\text { - The Widening Digital Participation } \\
\text { programme was set up to help the millions } \\
\text { of people who lack the confidence and } \\
\text { skills to access and use digital health } \\
\text { services and information and benefit from } \\
\text { their convenience } \\
\text { - From } 2013 \text { to 2016, more than 200,000 } \\
\text { "digital muggles" (e.g., older people, } \\
\text { socio-economically deprived and excluded } \\
\text { groups) and 8,000 local digital champions/ } \\
\text { volunteers were trained } \\
\text { - 54\% of learners in need of non-urgent } \\
\text { medical advice said they would now go to } \\
\text { the Internet before consulting their GP }\end{array}$ & UK \\
\hline
\end{tabular}

\section{Workforce}

\section{Awareness}

Education and

skills
- HCPs and other professionals fully understand the scope of personalised health care

- HCPs are encouraged to take a holistic, multimodal approach to their patients' health - Other professionals (e.g., data analysts, care workers, coaches) are increasingly involved in people's health and well-being

- Awareness and education campaigns are in place to ensure that all professionals have a clear view of how they should operate within personalised health care
- HCPs and other professionals (incl. regulators, government stakeholders, other agencies) are fully literate in digital health, health data and new technologies

- Coordinated educational programmes (e.g., medical training, dedicated masters and $\mathrm{PhD}$ courses) ensure that the right knowledge and skills are being developed, nationally and locally

- Additional hands-on, practical training is available as part of continuing medical education, covering medical software, devices, technologies, best practices in data collection, and other topics
Personalised Medicine and Novel

\section{Therapies MSc by UCL [91]}

- UCL Personalised Medicine and Novel

Therapies Masters programme offers advanced education for HCPs and other professionals

- It builds awareness sharing on a breadth

of personalised health care topics
UK

USA
***
Latin America

[92]

- NorthShore University invested USD 7.5

million to train staff on new digital systems in the first 3 years

- This facilitated quick uptake and high completion compliance ***

Informatics Training for Global Health programme from the Fogarty International Center [93]

- The Fogarty International Center has supported informatics research training in low- and middle-income country institutions in partnership with US institutions and investigators

- It has funded several collaborative research and training programmes in Latin America and played a significant role in expanding the informatics workforce based on the health and informatics needs in Latin America 
Table 3 (continued)

\begin{tabular}{|c|c|c|c|}
\hline Enabler & Element description & Element example & Country \\
\hline $\begin{array}{l}\text { Capability } \\
\text { planning }\end{array}$ & $\begin{array}{l}\text { - The number and capabilities of current } \\
\text { professionals involved in personalised health } \\
\text { care are mapped, to determine which } \\
\text { capabilities are critical versus preferable (incl. } \\
\text { people and financial resources) and how } \\
\text { prevalent these are (inc. in urban vs. rural } \\
\text { settings) } \\
\text { - A dedicated capacity plan and forecasting are } \\
\text { in plan to provide a short-, medium-, and } \\
\text { long-term view of the multidisciplinary } \\
\text { workforce (e.g., collaborating across therapy } \\
\text { areas) and the different means of ensuring } \\
\text { their education/skills (e.g., via training } \\
\text { programmes) }\end{array}$ & $\begin{array}{l}\text { Support for the health workforce } \\
\text { planning and forecasting expert } \\
\text { network (SEPEN) [94] } \\
\text { - Expertise and knowledge sharing on } \\
\text { improving health workforce is to be driven } \\
\text { through SEPEN, a European expert } \\
\text { network on planning and forecasting, to } \\
\text { increase expertise and knowledge sharing } \\
\text { for the health workforce } \\
\text { - It aims to develop expert networking to } \\
\text { structure and exchange knowledge, map } \\
\text { national health workforce policies in all EU } \\
\text { countries, foster the exchange of } \\
\text { knowledge and good practices on health } \\
\text { workforce through European workshops, } \\
\text { and provide tailored support to some } \\
\text { countries on national implementation of } \\
\text { health workforce planning }\end{array}$ & Europe \\
\hline
\end{tabular}

\section{Collaboration}

Knowledge

networks
- Best practices for personalised health care are shared openly, systematically, and efficiently through individual, institutional, or geographical collaborations (involving all relevant stakeholders)

- Expert and consultation networks are used to systematise best practice sharing - Publicly-available and widely disseminated findings and recommendations

Innovation hubs
- Centres of excellence, innovation hubs, incubators and/or accelerators are in place, well-funded and able to provide support and advice to innovate in personalised health care - Digital health solutions and other innovations in personalised health care are iterated, tested, and disseminated through the hubs

- There is strong reliance on best practice sharing and agile methods of working (e.g., piloting and scaling)

\section{European Institute of Innovation and Technology Health Initiative [95] \\ - The European Institute of Innovation and Technology Health initiative connects 90 partners from public and private organisations \\ - The aim of this network is to accelerate innovation and development of health services by sharing best practice and investing EUR 2 billion}

\section{Cross-sector accelerator CoLab in}

Denmark [96]

- The CoLab accelerator aims to facilitate market entry of MedTech solutions, via collaboration of industry, communities, and hospitals at 6 local development and test facilities

- Patients and carers are surveyed for their views and participate in development ***

\section{Boston Health Tech Innovation Hub} [97]

- The Boston Health Tech Innovation Hub has supported 1,221 start-ups of which $12 \%$ in health care

- It has invested USD 3.2 billion in health tech start-ups

- Partners include Boston University, Northeastern University, and UMass Boston, and with investors Techstars, Healthbox, and Masschallenge

- For example, the hub supported start-ups to aggregate health data or manage respite and home care services
Europe

Denmark ***

USA 
Table 3 (continued)

\begin{tabular}{|c|c|c|c|}
\hline Enabler & Element description & Element example & Country \\
\hline $\begin{array}{l}\text { Multiparty } \\
\text { bidding for } \\
\text { health services }\end{array}$ & $\begin{array}{l}\text { - Private enterprises, patient associations, and } \\
\text { other non-government entities can bid to } \\
\text { provide personalised health care services and/ } \\
\text { or products (e.g., telehealth, EHR provision, } \\
\text { chronic cancer support) } \\
\text { - New service providers are seen as } \\
\text { trustworthy and value-adding, and are not } \\
\text { kept away from or penalised in contracts for } \\
\text { personalised health care provision }\end{array}$ & $\begin{array}{l}\text { Openness to any suitable provider to } \\
\text { support health system in Valencia [98] } \\
\text { - Any willing stakeholders (incl. private } \\
\text { entities) can engage in the health system } \\
\text { and provide services } \\
\text { - Transparent KPI requirements (e.g., } \\
\text { surgeries per day, waiting lists, access, } \\
\text { patient satisfaction) are shared with } \\
\text { interested parties, to allow any qualified } \\
\text { stakeholder to participate }\end{array}$ & Spain \\
\hline $\begin{array}{l}\text { Health system } \\
\text { partnerships }\end{array}$ & $\begin{array}{l}\text { - Partnerships with all relevant stakeholders } \\
\text { (e.g., health providers, insurers, NGOs, patient } \\
\text { associations, pharma and med tech companies, } \\
\text { tech companies, etc.) are in place, run } \\
\text { smoothly, and are well received } \\
\text { - These partnerships - incl. but not limited to } \\
\text { public-private partnerships - have a clearly } \\
\text { defined purpose, responsibilities, governance, } \\
\text { standards, and communication pathways to } \\
\text { enable collaboration, use of best practice, and } \\
\text { data sharing } \\
\text { - The responsibilities of public and private } \\
\text { entities within these partnerships are well } \\
\text { established }\end{array}$ & $\begin{array}{l}\text { Productive development partnerships } \\
\text { in Brazil [99] } \\
\text { - The aim of productive development } \\
\text { partnerships is for public institutions to } \\
\text { have the production technology to receive } \\
\text { technology from the private sector, to } \\
\text { develop the critical inputs, and jointly } \\
\text { produce with the private sector in order to } \\
\text { deliver the final product to the Unified } \\
\text { Health System } \\
\text { - This provides an annual economy of } \\
\text { about USD 1.5 billion to the Brazilian } \\
\text { Government, of which USD } 50 \text { million are } \\
\text { for medical devices } \\
\text { *** } \\
\text { Public-private partnership at Genomics } \\
\text { England } \\
\text { - Genomics England 100,000 Genomes is a } \\
\text { repository of genomic test results, to } \\
\text { enable genomic and personalised } \\
\text { therapies } \\
\text { - Initially public, it is now a successful } \\
\text { public-private partnership } \\
\text { *** } \\
\text { ASPiRATION project [100] } \\
\text { - ASPiRATION is a genomic profiling } \\
\text { research project for } 1,000 \text { Australians with } \\
\text { newly diagnosed metastatic, } \\
\text { non-squamous, non-small-cell lung cancer } \\
\text { - The project is funded by the Australian } \\
\text { government's Medical Research Future } \\
\text { Fund and by Roche } \\
\text { - It will be conducted by the Australian } \\
\text { Genomic Cancer Medicine Centre, the } \\
\text { Australasian Lung Cancer Trials Group, } \\
\text { and the National Health and Medical } \\
\text { Research Council Clinical Trials Centre }\end{array}$ & $\begin{array}{l}\text { Brazil } \\
* * * \\
\text { UK } \\
* * * \\
\text { Australia }\end{array}$ \\
\hline
\end{tabular}


Table 3 (continued)

\begin{tabular}{lll}
\hline Enabler $\quad$ Element description $\quad$ Element example \\
\hline
\end{tabular}

\section{System incentives}

Incentives for patient participation
- A comprehensive set of transparent system incentives and nudges is in place to enable personalised health care by improving adherence/compliance and strengthening patient involvement

- These tailored incentives span across all settings of care and are continuously monitored and adjusted as needed to ensure their positive impact

- Rewards for contribution/participation can include: declining copayments for adherence, subsidies when immunisation targets or preventative behaviours are met, etc.
Wellth/Mount Sinai patient compliance program [101, [102]

- Wellth, a digital health company based in New York, has developed a system that provides patients with daily financial incentives to improve their compliance with drug regimens

- The patient sends a photo of their medication in their hand, to verify that they are successfully taking it, and receives a financial reward

- Supported by a grant from Health 2.0 and the New York City Economic Development Corporation, the Mount Sinai Health System has enrolled 12 patients in a pilot study with start-up Wellth

\begin{tabular}{ll}
\hline Incentives for & - A comprehensive set of transparent system \\
value-based care & incentives is in place to enable personalised \\
& health care by improving the quality/targeting \\
of care provided by HCPs and other & professionals \\
& - These tailored incentives span across all \\
& settings of care and are continuously \\
& monitored and adjusted as needed to ensure \\
& their positive impact \\
& - Incentives can support: following \\
& appropriate referral pathways (e.g., \\
& appropriate referrals to genomic testing), \\
& collaboration in multidisciplinary teams, \\
& decreased waste (e.g., reducing overtreatment \\
& and unnecessary interventions, focusing on \\
& high-value care) \\
& - Incentives can include: bonuses, \\
& non-financial support, etc.
\end{tabular}

Incentives for data - A comprehensive set of transparent system incentives/nudges is in place that enables personalised health care by improving the amount, quality, and sharing of health and health-relevant data

- These tailored incentives span across all settings of care and are continuously monitored and adjusted as needed to ensure their positive impact

- Incentives can support completion and quality of EHRs, discounts/cashback for use of digital tools, or mobile devices with regular data input

$\begin{array}{ll}\text { System incentives for HCPs if enrolling } & \text { Germany } \\ \text { patients into a qualified disease } & * * * \\ \text { management programme [103] } & \text { UK }\end{array}$

- Disease management programmes provide a proactive, multicomponent approach, integrating care across diseases and their complications, to reduce variation of care

- HCPs adhere to programme protocols and educate patients about self-care - Lower copayments are offered for enrolled patients for their medications ***

Cross-party collaboration for grants

- In the UK, funding bodies are asking academia to demonstrate that broader stakeholders (e.g., patients, clinical associations) are involved in research and initiatives

\section{Human Brain Project's medical} informatics platform [104]

- The Human Brain Project is a global open-source platform that allows hospitals and research centres worldwide to share medical data

- Access to the platform is contingent upon sharing of own data, promoting a collaborative approach to data collection and analysis
USA

UK

EU 
Table 3 (continued)

\begin{tabular}{|c|c|c|c|}
\hline Enabler & Element description & Element example & Country \\
\hline $\begin{array}{l}\text { Incentives for } \\
\text { innovation }\end{array}$ & $\begin{array}{l}\text { - A comprehensive set of transparent system } \\
\text { incentives is in place for innovation, } \\
\text { investment and R\&D in personalised health } \\
\text { care priorities (e.g., digital tools for elderly) } \\
\text { and frontier digital technologies (e.g., AI, } \\
\text { blockchain, Big Data) } \\
\text { - Incentives are available to both large } \\
\text { companies and start-ups, to build up } \\
\text { traditional areas and innovative tech } \\
\text { ecosystems (e.g., incentivise PPPs that support } \\
\text { personalised health care values) }\end{array}$ & $\begin{array}{l}\text { Bio Convergence Technology } \\
\text { Laboratory [105] } \\
\text { - The Bio Convergence Technology } \\
\text { Laboratory is an ecosystem where SMEs, } \\
\text { joint ventures, start-ups and big } \\
\text { enterprises coexist in Songdo International } \\
\text { City } \\
\text { - The goal was to create } 6,000 \text { jobs across } \\
250 \text { companies, including } 90 \text { SMEs and } \\
160 \text { venture and start-up companies in } \\
\text { bio, beauty, and medical devices } \\
\text { - Designated as Korea's first free economic } \\
\text { zone for foreign investors doing business } \\
\text { in the area }\end{array}$ & South Korea \\
\hline
\end{tabular}

Category: health information and IT infrastructure

\section{Data legislation, guidance, and standards}

Legal and ethical - Evidence-based legal and ethical frameworks frameworks for data

are in place to support the effective management of health and genomic data, addressing data privacy and sharing, primary and secondary uses of data for research and personal purposes, security and protection, personal and societal impact of data and new technologies, etc.

- These legal frameworks are rigorous enough to provide clear guidance but remain flexible enough to be updated regularly in response to the dynamic nature of technology - Legal frameworks are aligned nationally and, where possible, internationally, building on best practice from across the globe

\section{HMA EMA Joint Big Data Taskforce}

[106]

- The HMA EMA Joint Big Data Taskforce assessed regulatory and ethical acceptability of big data analyses - It aims to increase legal and ethical transparency around health data standardisation, quality, sharing, and use ***

\section{National Digital Care Act in Switzerland} [107]

- The Swiss National Digital Care Act covers the governance of EHRs, apps, and health data to harmonise security and privacy policies

- It ensures that patients can safely access records

***

\section{Finnish Act on the Secondary Use of} Health and Social Data [108]

- The purpose of the Finnish Act on the Secondary Use of Health and Social Data is to facilitate the effective and safe processing and access to the personal social and health data for steering, supervision, research, statistics, and development in the health and social sector

- A second objective is to guarantee an individual's legitimate expectations as well as their rights and freedoms when processing personal data
Europe

***

Switzerland

***

Finland 
Table 3 (continued)

\begin{tabular}{|c|c|c|c|}
\hline Enabler & Element description & Element example & Country \\
\hline Data standards & $\begin{array}{l}\text { - Clear, aligned standards are in place to } \\
\text { govern the full data journey - from data } \\
\text { collection, interoperability, linkage, quality, } \\
\text { analysis, and storage } \\
\text { - These include: cross-stakeholder common } \\
\text { data models and standards for consent, } \\
\text { cleaning, use; open-access standards and } \\
\text { certifications for maximum interoperability } \\
\text { and integration; standardised and widely used } \\
\text { personal health identifiers; principles of clear } \\
\text { identification of the data source, etc. } \\
\text { - These standards are re-assessed regularly, in } \\
\text { line with the fast-paced development of new } \\
\text { technologies }\end{array}$ & $\begin{array}{l}\text { Observational Medical Outcomes } \\
\text { Partnership Oncology [109] } \\
\text { - Observational Medical Outcomes } \\
\text { Partnership Oncology was launched in } \\
\text { 2017, with its first outputs published in } \\
2018 \\
\text { - It aims to transform data into a common } \\
\text { format with common terminology across } \\
\text { oncology and entails strong collaboration } \\
\text { with academia } \\
\text { - It incorporates EMRs histology records } \\
\text { and diagnostic/treatment/outcome data }\end{array}$ & Global \\
\hline $\begin{array}{l}\text { Governance and } \\
\text { process for access }\end{array}$ & $\begin{array}{l}\text { - Clear, aligned governance and transparent } \\
\text { processes are in place to govern access, } \\
\text { transfer, and sharing of health data records } \\
\text { - These include: patient access to their own } \\
\text { health data; secondary use of data for } \\
\text { institutional and personal uses; national and } \\
\text { cross-border collaboration that does not } \\
\text { require localisation of data hosting (e.g., } \\
\text { cloud-based systems that may be based in } \\
\text { other countries); governance of NGS data } \\
\text { outcomes; etc. } \\
\text { - Data controllers are allowed to use, share } \\
\text { and/or transfer data within their use } \\
\text { - The aim is to limit cybersecurity or } \\
\text { de-anonymization risks, including clear } \\
\text { protocols for deviations }\end{array}$ & $\begin{array}{l}\text { Buurtzorg nursing admin and data } \\
\text { software [110] } \\
\text { - Buurtzorg is a modern IT system that } \\
\text { enables online scheduling, documentation } \\
\text { of nursing assessments and services, } \\
\text { billing and sharing of information within } \\
\text { and across teams } \\
\text { *** } \\
\text { Dubai Health Authority Dashboard } \\
\text { [111] } \\
\text { - The Dubai Health Authority has a } \\
\text { dashboard of public health data for the } \\
\text { government, based on existing databases } \\
\text { and information completed by HCPs } \\
\text { - This provides visibility on disease trends } \\
\text { *** } \\
\text { MEGA 1 Million Genome Initiative [112] } \\
\text { - Launched in 2018, the MEGA } 1 \text { Million } \\
\text { Genome Initiative is a collaboration } \\
\text { mechanism between } 21 \text { Member States } \\
\text { and Norway, with the potential to improve } \\
\text { disease prevention, allow for more } \\
\text { personalised treatments, and provide a } \\
\text { sufficient scale for new clinically impactful } \\
\text { research } \\
\text { - The aim is to have least } 1 \text { million } \\
\text { sequenced genomes available in the EU by } \\
\text { 2022 }\end{array}$ & $\begin{array}{l}\text { The } \\
\text { Netherlands } \\
* * * \\
\text { United Arab } \\
\text { Emirates } \\
* * * \\
\text { Europe }\end{array}$ \\
\hline
\end{tabular}


Table 3 (continued)

\begin{tabular}{|c|c|c|c|}
\hline Enabler & Element description & Element example & Country \\
\hline Secure software & $\begin{array}{l}\text { - Systems, processes, and technologies are in } \\
\text { place to securely link, transfer, and share data } \\
\text { (e.g., for clinical and research purposes) } \\
\text { - These facilitate the collection and use of data } \\
\text { by being user-friendly and intuitive, while } \\
\text { guaranteeing the security of collected } \\
\text { information throughout its journey between } \\
\text { users }\end{array}$ & $\begin{array}{l}\text { National Bio Big Data [113] } \\
\text { - Five major big data platforms were built } \\
\text { as the foundation for bio-health innovation } \\
\text { is data } \\
\text { - The core platform is the "National Bio } \\
\text { Big Data," launched to collect genomic, } \\
\text { medical, and health information from up to } \\
1 \text { million volunteers, and to use the } \\
\text { collected information to develop } \\
\text { patient-customised drugs } \\
\text { *** } \\
\text { TIBU digital health system [114] } \\
\text { - Initially focused on tuberculosis } \\
\text { treatment, TIBU integrates the ministerial } \\
\text { facilities and administrative offices with } \\
\text { National Health Information System } \\
\text { (DHIS/2) providing real-time data on } \\
\text { patients, treatment, and outcome, drug } \\
\text { availability, lab inventory, and real-time } \\
\text { payments made to the patients using the } \\
\text { mobile payment platform M-PESA }\end{array}$ & $\begin{array}{l}\text { South Korea } \\
* * * \\
\text { Kenya }\end{array}$ \\
\hline
\end{tabular}

\section{IT infrastructure}

IT architecture - A clearly defined architecture is in place for and capacity

digital services, including models of information and common lexicon/terminology (e.g., to promote interoperability) - There is a joint commitment to develop a common IT architecture and adopting set standards, including openness to cloud-based systems for storage

- Advanced computational capacity and bandwidth are established to manage complex operations at optimal speeds and store/ process growing amounts of data - Interoperability and sharing are at the core of the architecture, with IT used to connect different systems - standardised unique personal health identifiers (or other mechanisms to link different data sets covering a single person) are used across health and other systems, with a clear understanding of ethical and privacy implications
Monitoring of - Data processes and IT delivery are assessed

data, IT, and

processes regularly (e.g., digital maturity, interoperability) to ensure that the right services and technologies are in place - KPIs are used to track performance of digital systems and processes (e.g., data quality) - Outputs from these assessments are used to make evidence-based recommendations for digital implementations and future decisions - Relevant agencies champion data interoperability and standards

\section{Danish unique personal health identifiers [115]}

- In Denmark, unique personal health identifiers are issued to all citizens at birth alongside a secure web ID for online EHR access

- The identifier links patient details to one of the 15 interoperable EHR systems and alerts patients by e-mail if an HCP views records

- There are financial incentives for HCPs to use the identifiers, as well as centrally

funded technical support

***

IT and EHR system at NorthShore

University [116]

- NorthShore University has developed a clear IT strategy and architecture plan, based on experience with stand-alone IT systems, to develop an integrated solution
Denmark

***

USA

\section{eHealth Digital Service Infrastructure [117]}

- Launched in 2015, it is intended to allow doctors to share electronic patient summaries and issue prescriptions across borders

- The first transfers took place in 2019, between Finland and Estonia
Europe 
Table 3 (continued)

\begin{tabular}{ll}
\hline Enabler & Element description \\
\hline 8. Data sources and software \\
$\begin{array}{ll}\text { Registries and } \\
\text { genomic data }\end{array}$ \\
$\begin{array}{ll}\text { repositories } & \text { High-quality, long-term data sources (e.g., } \\
& \text { health data to help personalise health care for } \\
& \text { individual patients and populations } \\
& \text { - These data extend beyond health care, to } \\
& \text { provide a comprehensive picture (e.g., } \\
& \text { geographic, socio-economic, outcomes) } \\
& \text { - Data sources are interoperable to ensure } \\
& \text { breadth, depth, and effective use of data } \\
& \text { - There is national and international } \\
& \text { collaboration to enable complete information } \\
& \text { sharing }\end{array}$
\end{tabular}

Element example

Country

\section{Genomics England 100,000 Genomes \\ [118] \\ UK \\ $* * *$}

- Genomics England 100,000 Genomes is a

repository of genomic test results, to

enable genomic and personalised

therapies

- The database was launched in 2012, with

the final patient recruited in 2018

- Its aim is to enable new scientific

discoveries, medical insights, and

advanced diagnostics

***

\section{Estonian Biobank [119]}

- The Estonian Biobank was launched in

2000

- Its aim is to collect information on the health of the Estonian population and their genes, study this cohort scientifically from both genetic and medicals aspects, and use the data obtained to improve national health standards

- In 2018, the first biobank participants started receiving their personal genetic reports

\begin{tabular}{|c|c|c|c|}
\hline $\begin{array}{l}\text { Electronic health } \\
\text { records }\end{array}$ & $\begin{array}{l}\text { - EHRs are in place across all settings of care, } \\
\text { with high adoption, completion rates, and } \\
\text { quality } \\
\text { - Records pull from numerous health-related } \\
\text { sources (e.g., care providers, devices, claims, } \\
\text { prescription data) and non-health-related } \\
\text { sources (e.g., geolocalisation) } \\
\text { - Patients and HCPs have access and training } \\
\text { to amend, consult, and use the data "live" } \\
\text { - EHR data can be used for health management } \\
\text { and decisioning, as well as research (e.g., using } \\
\text { anonymised data) } \\
\text { - A coordinated function leads on EHRs, data, } \\
\text { privacy, and knowledge sharing, with clear } \\
\text { governance and pathways that allow access } \\
\text { and integration with non-health data } \\
\text { - Constant quality, consent, and security } \\
\text { surveillance of EHRs and other sources of } \\
\text { health data (e.g., via a security operations } \\
\text { centre) is in place }\end{array}$ & $\begin{array}{l}\text { National EHR in Denmark [120] } \\
\text { - The centralized electronic database of its } \\
\text { citizens' medical records goes back as far } \\
\text { as } 1977 \text { for basic records and back as far } \\
\text { as } 2000 \text { for detailed histories } \\
\text { - Approximately } 98 \% \text { of primary care } \\
\text { physicians have access to the system, } \\
\text { including all hospital physicians and all } \\
\text { pharmacists } \\
\text { *** } \\
\text { National EHR in Denmark } \\
\text { - A nationwide "birth-to-death" electronic } \\
\text { health record system is in place for nearly } \\
\text { every citizen }\end{array}$ & $\begin{array}{l}\text { Denmark } \\
\text { *** } \\
\text { Estonia }\end{array}$ \\
\hline
\end{tabular}


Table 3 (continued)

\begin{tabular}{|c|c|c|c|}
\hline Enabler & Element description & Element example & Country \\
\hline $\begin{array}{l}\text { Integration of new } \\
\text { technologies for } \\
\text { data }\end{array}$ & $\begin{array}{l}\text { - User-friendly, intuitive tools and software } \\
\text { are in place to capture, aggregate, clean, } \\
\text { enhance, and analyse data } \\
\text { - These softwares collect RWD in existing } \\
\text { health systems and beyond (e.g., wearables, } \\
\text { media) and are designed for interoperability } \\
\text { and sharing, with tools progressively replacing } \\
\text { more traditional means of data collection (e.g., } \\
\text { paper, voice recordings) } \\
\text { - There us a robust understanding of potential } \\
\text { applications of current and future data } \\
\text { technologies, analyses, and outputs (e.g., } \\
\text { clinical decision support, health system } \\
\text { dashboards), with constant evaluation and } \\
\text { testing of new technologies to improve the full } \\
\text { data lifecycle (e.g., AI to clean and enrich data, } \\
\text { GIS to visualize data, SaMD) and/or integrate } \\
\text { across domains/sources at the superordinate } \\
\text { level (e.g., via EHRs) }\end{array}$ & $\begin{array}{l}\text { Health information system } \\
\text { HealthConnect [121] } \\
\text { - HealthConnect involves tools given to } \\
\text { patients to manage their own health and } \\
\text { experience (e.g., virtual consultations) } \\
\text { - This includes digital medical refill } \\
\text { requests, virtual consultations, AI support, } \\
\text { etc. }\end{array}$ & USA \\
\hline
\end{tabular}

Category: health services

\section{Public health and prevention}

Prevention and - Prevention is seen as an essential part of the health promotion health continuum, with efforts targeting primary, secondary, and tertiary prevention as part of the overarching health strategy - Screening, early detection, health promotion, follow-up for disease progression/relapse, awareness campaigns, etc. are targeted towards populations at risk in order to improve health-related behaviours and foster a healthy society

\section{LC-SCRUM - Japan [122]}

Japan/Asia

- LC- SCRUM- Japan is a genomic screening project conducted by the National Cancer Center Japan in cooperation with medical institutions and pharmaceutical manufacturers across the country

- LC-SCRUM - Asia is an industryacademia collaborative cancer genome screening project for lung cancer patients, which uses state-of-the-art genetic testing technology to simultaneously examine multiple genetic changes that cause lung cancer (5 institutions in Taiwan and 161 in Japan)

\section{Kaiser Care Management Institute} [123] essential part of overall health management methods, leveraging data, risk stratification, predictive analytics, and other public health methods to identify at-risk populations - Outputs from these techniques (e.g., progress reports, health system dashboards) are used to plan and evaluate the provision of health across the population, to ensure optimal outcomes within allocated resources
- Each of Kaiser's geographic regions select care management priorities (such as diabetes, asthma, heart disease, or depression) based on the health needs of its members

- The Care Management Institute develops tools each region can use to develop care management strategies, then ships them to local implementation teams, which tailor care management programmes to their populations 
Table 3 (continued)

\begin{tabular}{|c|c|c|c|}
\hline Enabler & Element description & Element example & Country \\
\hline \multicolumn{4}{|c|}{ 10. Personalised health infrastructure } \\
\hline $\begin{array}{l}\text { Advanced } \\
\text { diagnostics }\end{array}$ & $\begin{array}{l}\text { - Basic diagnostic testing/screening/imaging/ } \\
\text { point-of-care infrastructure are in place (incl. } \\
\text { at primary care) to enable the accurate, timely } \\
\text { diagnosis of patients } \\
\text { - More advanced tests (incl. NGS) are offered } \\
\text { routinely and early in the process (i.e., for } \\
\text { triage), as needed, and used in both clinical/ } \\
\text { patient applications and research purposes } \\
\text { - Interpretation support is provided for } \\
\text { multimodal testing (e.g., clinical decision } \\
\text { support, AI, visualisation) } \\
\text { - Clinical guidelines and prescription practices } \\
\text { are in place to support the appropriate use of } \\
\text { basic and advanced diagnostics and how their } \\
\text { results should be interpreted and used (e.g., } \\
\text { sequencing across tumour type for tumour- } \\
\text { diagnostic health products, use of genomic } \\
\text { data and personal medical history to inform } \\
\text { HCP decisions), supported by appropriate } \\
\text { standards }\end{array}$ & $\begin{array}{l}\text { Norwegian Cancer Genomics } \\
\text { Consortium } \\
\text { - The Norwegian Cancer Genomics } \\
\text { Consortium began using NGS to test cancer } \\
\text { biopsies for personalised medicine } \\
\text { treatments in } 2012 \\
\text { - The second phase of the project has } \\
\text { received funding (USD } 7 \text { million) from the } \\
\text { BIOTEK } 2021 \text { programme }\end{array}$ & Norway \\
\hline $\begin{array}{l}\text { Remote } \\
\text { monitoring }\end{array}$ & $\begin{array}{l}\text { - Remote monitoring and telehealth are widely } \\
\text { used to support the continuous management } \\
\text { and support of patients, providing the bridge } \\
\text { between traditional settings of care and } \\
\text { community care } \\
\text { - These technologies help reach at-risk or } \\
\text { remote groups (e.g., rural patients) and } \\
\text { support personal choices (e.g., preference for } \\
\text { home care) }\end{array}$ & $\begin{array}{l}\text { Babylon Health telemedicine solution } \\
\text { [124] } \\
\text { - Babylon Health provides accessible } \\
\text { preventative consultations and diagnostics } \\
\text { (e.g. RR, pulse) via an app } \\
\text { - It offers integrated point-of-care tests } \\
\text { and referrals between app, local GPs, and } \\
\text { other providers }\end{array}$ & UK \\
\hline $\begin{array}{l}\text { Personal devices } \\
\text { and mHealth }\end{array}$ & $\begin{array}{l}\text { - Personal devices (e.g., wearables, apps) are } \\
\text { widely used to support prevention, } \\
\text { communication, treatment, recovery, constant } \\
\text { monitoring, and data collection, (e.g., RWD } \\
\text { collection) } \\
\text { - These help reach at-risk or remote groups } \\
\text { (e.g., rural patients) and support personal } \\
\text { choices (e.g., home care via telemedicine) } \\
\text { - The consumer health data that are collected } \\
\text { from these devices can be integrated in } \\
\text { broader health decisioning }\end{array}$ & $\begin{array}{l}\text { Wearable devices and monitoring (e.g., } \\
\text { smart watches, Fitbits, speedometer) in } \\
\text { Dubai [125] } \\
\text { - Dubai has promoted the use of various } \\
\text { self-assessment apps, data sharing with } \\
\text { clinicians, and devices linked with EHRs } \\
\text { - It is still lacking one consolidated } \\
\text { pathway, but there is rapidly growing } \\
\text { uptake by patients }\end{array}$ & $\begin{array}{l}\text { United Arab } \\
\text { Emirates }\end{array}$ \\
\hline
\end{tabular}


Horgan et al.: Propelling Health Care into the Twenties

Table 3 (continued)

\begin{tabular}{|c|c|c|c|}
\hline Enabler & Element description & Element example & Country \\
\hline $\begin{array}{l}\text { Integration of new } \\
\text { technologies for } \\
\text { health }\end{array}$ & $\begin{array}{l}\text { - New technologies are assessed and tested } \\
\text { regularly to improve personalised patient } \\
\text { journeys, from prevention to chronic care (e.g., } \\
\text { telehealth, apps, AR/VR) } \\
\text { - These are fully integrated into the patient } \\
\text { health journey, rather than added on to certain } \\
\text { parts of the pathway } \\
\text { - Predictive techniques are used to support } \\
\text { local health systems in planning care provision } \\
\text { - Clinical decision support and AI are used to } \\
\text { help clinicians apply best practice and provide } \\
\text { optimal patient care, by providing timely } \\
\text { information to clinicians, patients, and others } \\
\text { to inform decisions about health care }\end{array}$ & $\begin{array}{l}\text { Artificial intelligence at Xiangya } \\
\text { Hospital [126] } \\
\text { - Xiangya Hospital uses data collected } \\
\text { from patients (e.g., scans, photos, notes, } \\
\text { etc.) to inform and test an AI algorithm for } \\
\text { dermatology, then launched the first } \\
\text { dermatology Internet hospital licensed to } \\
\text { operate online in China } \\
\text { - It launched an interactive app that } \\
\text { enables patients to upload their medical } \\
\text { history, including pictures, ahead of an } \\
\text { appointment, to free up time for the actual } \\
\text { diagnosis when visiting a clinician } \\
\text { - It has conducted a "smart cervical cancer } \\
\text { screening" programme, which assists in } \\
\text { examining } 60 \text { million women annually by } \\
\text { reducing the time it takes to evaluate the } \\
\text { involved Pap test slices } \\
\text { *** } \\
\text { Canadian Personalized Healthcare } \\
\text { Innovation Network } \\
\text { - The Canadian Personalized Healthcare } \\
\text { Innovation Network brings the Canadian } \\
\text { health care system together to use the } \\
\text { power of data to improve health outcomes } \\
\text { for Canadians } \\
\text { - The goal of their Lung Kick Start } \\
\text { Program is to determine, through RWD, } \\
\text { the sequencing of testing and treatment } \\
\text { that produces the best health outcomes for } \\
\text { specific lung cancer patients }\end{array}$ & $\begin{array}{l}\text { China } \\
* * * \\
\text { Canada }\end{array}$ \\
\hline
\end{tabular}

\section{Patient-centric care model}

Patient-centred - High-quality, reliable health infrastructure is

health

infrastructure

in place that can be accessed and navigated by all, with the right care centres and specialists available in the vicinity (e.g., hub and spoke model)

- Care consent frameworks strengthen patient understanding and efficiency - these can readily be amended, assigned, or revoked, and there is rapid and full access of agreed information to agreed parties after consent - The infrastructure enables evidence-based care for one, e.g. using dynamic labelling/ patient-specific information/patient-relevant product information

- Health management and treatment decisions are based on the most appropriate patient information (e.g., tumour sequencing based on sequencing rather than morphology) and consider outcomes that matter to patients

\section{Ping An Good Doctor [127]}

China

- The Ping An Good Doctor is a one-stop health care ecosystem that caters to the needs of adults, the elderly, and children by appointing dedicated doctors to conduct one-on-one consultations - It also acts as "health butler" that integrates the services in medical and health care sectors, i.e. by developing an electronic health profile, customising a physical check-up plan, compiling medical reports, tracing abnormal health indicators, and managing weight for users 
Table 3 (continued)

\begin{tabular}{|c|c|c|c|}
\hline Enabler & Element description & Element example & Country \\
\hline $\begin{array}{l}\text { Pathways for } \\
\text { patient-HCP } \\
\text { communications }\end{array}$ & $\begin{array}{l}\text { - Two-way communication pathways are in } \\
\text { place between patients and their families, and } \\
\text { HCPs and other professionals, to support } \\
\text { shared decision-making based on appropriate } \\
\text { levels of information (e.g., outcomes that } \\
\text { matter to patients) and empower patients } \\
\text { - The full range of the patient support network } \\
\text { can be involved as needed (incl. family, friends, } \\
\text { carers, patient associations) } \\
\text { - Continuous communication, coordination, } \\
\text { and data flows are systematically enabled } \\
\text { between patients and their HCPs, and } \\
\text { embedded into care pathways and care models } \\
\text { - Patients are confident in using digital } \\
\text { communication pathways, with alternatives } \\
\text { available if digital is unsuitable for them (e.g., } \\
\text { SMS, face-to-face) }\end{array}$ & $\begin{array}{l}\text { Lybrate app [128] } \\
\text { - The Lybrate app provides patients with a } \\
\text { one-click emergency support system, } \\
\text { search tool for nearby ambulance services } \\
\text { and book appointments with best doctors } \\
\text { - It allows patients to digitally store and } \\
\text { manage their medical records (incl. past } \\
\text { prescriptions, lab reports, allergies, etc.) } \\
\text { on their smartphone and share with their } \\
\text { doctors easily }\end{array}$ & India \\
\hline $\begin{array}{l}\text { Monitoring of } \\
\text { health and care }\end{array}$ & $\begin{array}{l}\text { - Personalised health care delivery is assessed } \\
\text { via the full range of outcomes (e.g., events, } \\
\text { re-admissions but also QoL, PROs, etc.) } \\
\text { - Global, national, and local standards are } \\
\text { established and used as benchmarks to } \\
\text { preserve quality of health delivered } \\
\text { - KPIs are used to track the quality of care } \\
\text { delivered and the outcomes for patients, } \\
\text { remove low-benefit practices, and ensure } \\
\text { equitable access to health } \\
\text { - Outputs from these assessments are used to } \\
\text { make evidence-based recommendations for } \\
\text { improvement in care processes }\end{array}$ & $\begin{array}{l}\text { World Health Organisation Global } \\
\text { Accelerated Action for the Health of } \\
\text { Adolescents [129] } \\
\text { - In 2015, the WHO/UNAIDS published the } \\
\text { Global standards to improve quality of } \\
\text { health-care services for adolescents } \\
\text { - Many countries have used the Global } \\
\text { Standards to adapt and adopt them } \\
\text { nationally (though these can be time- } \\
\text { consuming) } \\
\text { *** } \\
\text { Martini-Klinik in Germany [130] } \\
\text { - The Martini-Klinik, a specialist prostate } \\
\text { cancer clinic, systematically measures the } \\
\text { quality of its care using outcomes that are } \\
\text { most relevant to patients } \\
\text { - These data are shared with the health } \\
\text { care professionals at the clinic to } \\
\text { continually revise and improve care } \\
\text { - The clinic consistently performs better } \\
\text { than the German national average in terms } \\
\text { of treatment outcomes for patients with } \\
\text { prostate cancer } \\
\text { *** } \\
\text { Santeon hospital network in the } \\
\text { Netherlands [131] } \\
\text { - Santeon, a Dutch network of } 7 \text { leading } \\
\text { teaching hospitals, implemented value- } \\
\text { based health care by defining the right } \\
\text { metrics to improve outcomes, initiating a } \\
\text { strict and simultaneous cadence of } \\
\text { improvement cycles, and sharing results to } \\
\text { accelerate improvements } \\
\text { - It has achieved reductions of nearly } 30 \% \\
\text { in unnecessary inpatient stays and up to } \\
\text { complications in breast cancer patients }\end{array}$ & $\begin{array}{l}\text { Global } \\
* * * \\
\text { Germany } \\
* * * \\
\text { The } \\
\text { Netherlands }\end{array}$ \\
\hline
\end{tabular}


Table 3 (continued)

\begin{tabular}{|c|c|c|c|}
\hline Enabler & Element description & Element example & Country \\
\hline \multicolumn{4}{|c|}{ 12. Integrated care coordination } \\
\hline $\begin{array}{l}\text { Integrated care } \\
\text { coordination }\end{array}$ & $\begin{array}{l}\text { - Care is interoperable across all sectors of } \\
\text { health (e.g., community care and medical } \\
\text { specialists, public and private providers, } \\
\text { within and across regions, across siloed } \\
\text { specialties), applying to care plans and care } \\
\text { models } \\
\text { - General prevention management and care } \\
\text { delivery are controlled by a coordinated } \\
\text { function, with a traceable entry point into the } \\
\text { system (e.g., GP) and clear information flows } \\
\text { - Transparent and efficient referral pathways } \\
\text { enable seamless multidisciplinary care } \\
\text { - Community care/extramuralisation is } \\
\text { recognised and a full part of health } \\
\text { management } \\
\text { - This is informed by consultation with } \\
\text { patients and patient associations }\end{array}$ & $\begin{array}{l}\text { Integrated diabetes care system in the } \\
\text { Netherlands [132] } \\
\text { - The Dutch model for integrated care has } \\
\text { been pioneered in diabetes and led to } \\
\text { significant improvements in patient } \\
\text { outcomes } \\
\text { - It relies on having a single point of entry } \\
\text { into the programme and adopting a } \\
\text { coordinated, multidisciplinary approach, } \\
\text { with GPs strictly following national } \\
\text { standards } \\
\text { - Bundle payment for diabetes has been in } \\
\text { place since } 2007\end{array}$ & $\begin{array}{l}\text { The } \\
\text { Netherlands }\end{array}$ \\
\hline $\begin{array}{l}\text { Pathways for } \\
\text { HCP-HCP } \\
\text { communications }\end{array}$ & $\begin{array}{l}\text { - Digital tools, apps, and infrastructure are in } \\
\text { place between HCPs (e.g., primary vs. } \\
\text { secondary care, across different specialties), as } \\
\text { well as other health-related professionals (e.g., } \\
\text { coaches, nutritionists, psychologists, social } \\
\text { workers) } \\
\text { - These ensure that exchanges about people's } \\
\text { health are timely, secure, and seamless } \\
\text { amongst and across all stakeholders (e.g., via } \\
\text { chats, telehealth) } \\
\text { - This is informed by consultation with } \\
\text { patients and patient associations [133] [134] }\end{array}$ & $\begin{array}{l}\text { Doximity app [135] } \\
\text { - Doximity is a leading professional } \\
\text { medical network, with half of US } \\
\text { physicians as members } \\
\text { - It allows physicians to use their iPhone, } \\
\text { iPad, Android device or computer to } \\
\text { securely collaborate with other physicians, } \\
\text { review career opportunities, and stay } \\
\text { current on the latest medical news } \\
\text { - Physicians can send and receive patient } \\
\text { medical information through the platform }\end{array}$ & USA \\
\hline
\end{tabular}

Category: health products (i.e., medicines and therapeutics, diagnostics and other medicinal products)

\section{Legislation, policy, and guideline}

Legal and ethical - Evidence-based legal and ethical frameworks frameworks for are in place to govern the appropriate use of genetic and -omics gene editing and -omics (e.g., genomics, proteomics, biomics, etc.)

- These legal frameworks are rigorous enough to provide clear guidance but remain flexible enough to be updated regularly in response to the dynamic nature of technology, society, and innovation

- These cover topics such as: genetic discrimination; genomics privacy; genetic testing and tests; IP; etc.

- Legal frameworks are aligned nationally and, where possible, internationally, building on best practice from across the globe

\author{
Australian National Genomic Policy \\ Framework and Implementation Plan \\ 2018-2021 [136] \\ - The Australian National Genomic Policy \\ Framework and Implementation Plan \\ covers regulatory and legal approaches to \\ genomics implementation \\ - Key chapters cover genomic integration \\ into the national health system, policy \\ frameworks, and strategic priorities (e.g., \\ person-centred approach, workforce, \\ financing, services, data)
}


Table 3 (continued)

\begin{tabular}{|c|c|c|c|}
\hline Enabler & Element description & Element example & Country \\
\hline $\begin{array}{l}\text { Legal and ethical } \\
\text { frameworks for } \\
\text { digital health }\end{array}$ & $\begin{array}{l}\text { - Evidence-based legal and ethical frameworks } \\
\text { are in place to govern the appropriate use of } \\
\text { digital health (e.g., mHealth, wearables, and } \\
\text { related technologies) } \\
\text { - These legal frameworks are rigorous enough } \\
\text { to provide clear guidance but remain flexible } \\
\text { enough to be updated regularly in response to } \\
\text { the dynamic nature of technology, society, and } \\
\text { innovation } \\
\text { - These cover topics such as: use of new } \\
\text { technologies (e.g., AI); ownership of data } \\
\text { collected or shared via digital health; health } \\
\text { signal and response accountability, etc. } \\
\text { - Legal frameworks are aligned nationally and, } \\
\text { where possible, internationally, building on } \\
\text { best practice from across the globe }\end{array}$ & $\begin{array}{l}\text { WHO legal frameworks for e-health } \\
\text { [137] } \\
\text { - The WHO legal frameworks for e-health } \\
\text { ensure that appropriate legislations are at } \\
\text { the heart of e-health to enable and support } \\
\text { the provision of EHRs, e-prescriptions, etc. } \\
\text { - This includes non-binding guidance } \\
\text { based on the second global survey on } \\
\text { e-health } \\
\text { - There is a focus on ethical and legal } \\
\text { aspects of privacy in health care }\end{array}$ & Global \\
\hline
\end{tabular}

\section{R\&D and clinical trial models}

Support for R\&D - Continuous public and private funding is available for R\&D in health

- Research, where health products are shown to bring value, is actively translated into clinical practice through investment from all relevant parties

- Incentives are in place to specifically accelerate the translation of research into clinical practice above and beyond incentivising R\&D
Digital, patientcentric trials
- Clinical trials are conducted more robustly through the use of best practice, including the involvement of patients/patient associations in the design, running, and wrap-up of trials - Digital and other technologies (e.g., Internet of Things) are used to monitor patients, run trials efficiently, and obtain a broader set of data

\footnotetext{
New clinical trial - New models of clinical trials (e.g., single arm, models basket, and adaptive trials) are tested and rolled out in response to the unique characteristics of certain personalised health care products

- These models are used by both private and public researchers to evaluate health products - They are deemed relevant in regulatory, HTA/P\&R and/or pricing frameworks and models
}

\section{Australia's National Medical Health and Research Council \\ - The National Medical Health and \\ Research Council, which issues research grants, has recognised the issue around poor translation of research into clinical practice and actively incorporated a specific KPI in its annual report to improve on these figures \\ - It has adopted various mechanisms to accelerate translation for specific research projects}

\section{DNAnexus [138]}

- DNAnexus offers a cloud-based genomic data collaboration platform and launched a clinical trial solution that integrates the genomics data obtained from NGS into clinical studies

- Participants' DNA samples are sequenced and uploaded to the platform for analysis - Study clinicians can monitor the progress of analyses

- The platform is also integrated with a clinical trial management system to retrieve and store genomic results - Bioinformaticians can test and validate their pipelines and reports associated with the trial who are likely to respond to the treatment

Australia

Note: like the outcomes-based models, this can be tricky to convey as it is drug-related information; alternatively, could we use a collaboration or consensus paper on new trial models in order to avoid singling out specific products?
Global 
Table 3 (continued)

\begin{tabular}{|c|c|c|c|}
\hline Enabler & Element description & Element example & Country \\
\hline $\begin{array}{l}\text { 15. Regulatory fra } \\
\text { Innovative } \\
\text { regulatory } \\
\text { frameworks using } \\
\text { new data sources }\end{array}$ & $\begin{array}{l}\text { meworks } \\
\text { - Regulatory frameworks are in place that } \\
\text { provide transparency, guidance, and evidence } \\
\text { requirements for new medicines (incl. } \\
\text { molecularly guided therapies), technologies } \\
\text { (e.g., NGS), software (incl. clinical decision } \\
\text { support), etc. } \\
\text { - These pathways offer rigorous guidance for } \\
\text { products being evaluated, with flexibility to be } \\
\text { updated regularly due to the dynamic nature } \\
\text { of health and health products } \\
\text { - The regulatory methods reflect the nature of } \\
\text { the solution and evidence (e.g., RWD, modelled } \\
\text { data), accounting for different levels of } \\
\text { evidence and leveraging new types of data } \\
\text { (e.g., digital end points) } \\
\text { - There is clear guidance on situations in } \\
\text { which RWD is useful in regulatory decision- } \\
\text { making (incl. clinical context, sources of data, } \\
\text { study designs, quality/relevance, etc.) } \\
\text { - Informed and validated patient/patient } \\
\text { association input is incorporated across the } \\
\text { regulatory frameworks }\end{array}$ & $\begin{array}{l}\text { FDA 21st Century Cures Act, Dec } 2016 \\
\text { [139] } \\
\text { - The 21st Century Cures Act includes } \\
\text { regulatory policies intended to speed } \\
\text { patient access to new and breakthrough } \\
\text { medical devices } \\
\text { - It has a focus on discovery, innovation, } \\
\text { delivery, support, and financing of new } \\
\text { cures and devices } \\
\text { - It entails the provision of USD } 500 \\
\text { million over } 9 \text { years for the FDA to } \\
\text { implement new laws } \\
\text { *** } \\
\text { FDA and EMA Patient Engagement } \\
\text { Cluster [140] } \\
\text { - FDA and EMA have patient and } \\
\text { consumer clusters established across the } \\
\text { regulatory process } \\
\text { - They have institutionalised regular } \\
\text { collaboration and exchange processes with } \\
\text { clusters as well as between FDA and EMA } \\
\text { on an institutional level } \\
\text { - They developed a joint publication about } \\
\text { the value and how-to of patient } \\
\text { engagement }\end{array}$ & $\begin{array}{l}\text { USA } \\
* * * \\
\text { Europe }\end{array}$ \\
\hline $\begin{array}{l}\text { Integrated } \\
\text { regulatory } \\
\text { frameworks }\end{array}$ & $\begin{array}{l}\text { - Regulatory frameworks are in place that cut } \\
\text { across health products and technologies, } \\
\text { looking at the full continuum of care and/or } \\
\text { parallel technologies (e.g., NGS, clinical } \\
\text { decision support, etc.) } \\
\text { - Frameworks cover new technologies such as } \\
\text { NGS, software as medical device, clinical } \\
\text { decision support, etc. }\end{array}$ & $\begin{array}{l}\text { Note: as far as we can tell, this is not being } \\
\text { implemented anywhere in full (the closest } \\
\text { being the review of CDx with individual } \\
\text { drugs) }\end{array}$ & - \\
\hline
\end{tabular}


Table 3 (continued)

\begin{tabular}{lll}
\hline Enabler $\quad$ Element description $\quad$ Element example \\
\hline
\end{tabular}

\section{Innovative payment models}

Innovative HTA/P\&R pathways
- Pricing, reimbursement, and access pathways are in place that provide transparency, guidance, and evidence requirements for new medicines and therapeutics, to reinforce sustainable health systems

- HTA methods and processes reflect the nature of health products/technologies (e.g., digital solutions, products for small populations, phase 2 products, etc.), uncertainty, and available evidence (e.g., RWD, QoL, PROs), to ensure that value can be accurately assessed in a timely manner - Pathways balance uncertainty and new sources of evidence with the need to provide timely access to innovation - These pathways offer rigorous guidance for products being evaluated, with flexibility to be updated regularly due to the dynamic nature of health and health products

- Integration of informed and validated patient/patient association input across regulatory pathways

\section{Integrated} HTA/P\&R pathways

\begin{abstract}
- Pricing, reimbursement, and access pathways are in place that cut across health products and technologies, and consider broader societal value - These cover the full spectrum of care rather than a specific product or intervention, and/or consider their full impact on patients, carers, and societies (i.e., including outcomes, QoL, direct and indirect costs, intangible costs, ethical, legal, and organisational aspects, etc.)
\end{abstract}

\section{Therapeutic value of conditional innovation [141] \\ - The Haute Autorité de Santé is \\ France \\ *** \\ Germany} considering a new metric (therapeutic value of conditional innovation) which would apply to technologies with immature evidence bases

- It could replace the ASMR and would be re-evaluated periodically, as real-world evidence and further clinical trials become available

- For CAR-Ts, it has accelerated the frequency of assessments in order to review impending clinical trial data and RWD from the requested CAR-T registry ***

German Digital Care Act, 2019 [142]

- In 2019, Germany passed a law allowing doctors to prescribe digital apps with health benefits, which can be reimbursed by the country's health insurance system - The Federal Institute for Drugs and Medical Devices will check for issues such as data security, data protection, and functionality, and after that apps will be provisionally reimbursed by statutory health insurance

\section{Dental and Pharmaceutical Benefits} Board [143]

- The Swedish Dental and Pharmaceutical Benefits Board is a health technology assessment agency that sets the pharmacy purchase price level and pharmacy margin for reimbursed pharmaceuticals - It adopts a wide societal perspective, considering all costs and revenues for treatment and ill health including lost productivity, work loss, and time loss for the patient and their relatives, etc.

\begin{tabular}{ll}
\hline $\begin{array}{l}\text { Monitoring of } \\
\text { funding and } \\
\text { models }\end{array}$ & - Health funding (e.g., as a share of GDP), \\
& financing mechanisms (e.g., outcome-based \\
& etc.) and procurement approaches are \\
routinely evaluated, to ensure appropriate & investment in the health of populations while \\
& maintaining health system sustainability \\
& - KPIs are used to track performance of health \\
& systems and impact of funding (e.g., ROI, \\
& access, outcomes, etc.) \\
& - Outputs from these assessments are used to \\
& make evidence-based recommendations for \\
& investment decisions \\
& - Best practices from other countries are \\
& reviewed regularly to learn from best practices
\end{tabular}

$\begin{array}{ll}\text { Dubai Health Authority procurement } & \text { United Arab } \\ \text { KPIs [144] } & \text { Emirates }\end{array}$

- The Dubai Health Authority has established a set of KPIs to monitor funding, procurement, and provision of personalised health care, with guidance for all parties

Sweden
Emirates 
Table 3 (continued)

\begin{tabular}{|c|c|c|c|}
\hline Enabler & Element description & Element example & Country \\
\hline $\begin{array}{l}\text { Outcome-based } \\
\text { payment models }\end{array}$ & $\begin{array}{l}\text { - Data-enabled, innovative payment models } \\
\text { are in place for medicines and therapeutics, } \\
\text { diagnostics and medical devices, digital } \\
\text { solutions and other health products, to ensure } \\
\text { that health products are part of a sustainable } \\
\text { health system } \\
\text { - These include: conditional reimbursement, } \\
\text { outcome guarantee, payback scheme, free } \\
\text { initiation, etc. } \\
\text { - Transparent and holistic payment and } \\
\text { procurement processes are used to obtain } \\
\text { health products, with long-term investment, } \\
\text { while focusing on quality, services, and } \\
\text { sustainability of supply } \\
\text { - These models are based on data, reward } \\
\text { outcomes, and support innovation }\end{array}$ & $\begin{array}{l}\text { Managed entry agreements with the } \\
\text { Italian Medicines Agency [145, 146] } \\
\text { - Through the Italian agency AIFA, } \\
\text { conditional reimbursement agreements } \\
\text { are in place for most innovative medicines, } \\
\text { whereby payment is achieved where } \\
\text { agreed outcomes are met } \\
\text { - The aim is to ensure access to new } \\
\text { medicines for all patients while ensuring } \\
\text { health system sustainability } \\
\text { - Specific monitoring registries are in } \\
\text { place to evaluate managed entry } \\
\text { agreements and provide new, innovative } \\
\text { treatments } \\
\text { *** } \\
\text { Philips and Sanger risk-sharing } \\
\text { agreements [147] } \\
\text { - Philips and Atrium Health's Sanger Heart } \\
\text { and Vascular Institute signed a risk- } \\
\text { sharing agreement } \\
\text { - Led through the image-guided therapy } \\
\text { devices business, the 12-month agreement } \\
\text { links Philips' advanced imaging technology } \\
\text { capabilities to the achievement or } \\
\text { avoidance of critical outcomes for patients } \\
\text { with peripheral vascular disease }\end{array}$ & $\begin{array}{l}\text { Italy } \\
* * * \\
\text { USA }\end{array}$ \\
\hline
\end{tabular}

Integrated reimbursement approaches
- Innovative payment models cut across medicines and therapeutics, diagnostics and medical devices, digital solutions, and other health products

- These cover the full spectrum of care rather than a specific product or service, and/or a population rather than a specific patient - These include: staggered payment, valuebased bundles, portfolio deals, accountable care organisations, etc.

- Transparent and holistic payment and procurement processes are used to obtain health products, with long-term investment, while focusing on quality, services, and sustainability of supply - These models are based on data, reward outcomes, and support innovation

\section{Saudi Vision 2030 transformation [148]}

- As part of its Vision 2030, Saudi Arabia's health system is moving towards clusters that operate like accountable care organizations

- These will have capitated payment models
Saudi Arabia

HDR, health data research; RWD, real world evidence; ECH, European alliance connected health; EHR, electronic health record; EPF, European Patients Forum; HCP, health care professionals; GP, general practitioner; HTA, health technology assessment; UCL, University College London; KPI, key performance indicator; NGO, non-governmental organization; AI, artificial intelligence; PPP, public-private partnership; SME, small and medium enterprises; HMA, heads of medicines agencies; EMA, European Medicines Agency; EMR, electronic medical record; NGS, next-generation sequencing; GIS, geographic information system; SaMD, software as a medical device; RR, respiratory rate; AR/VR, augmented reality (AR) and virtual reality (VR); QoL, quality of life; PRO, patient-reported outcomes; IP, intellectual property; P\&R, pricing and reimbursement; CDx, companion diagnostics; ASMR, improvement of medical benefit (amélioration du service médical rendu); CAR-T, chimeric antigen receptor T; GDP, gross domestic product; ROI, return of investment.

compendium of how this approach is being followed around Europe and beyond [95-148]. It embraces elements as diverse as planning, infrastructure, and health services, products and workforce, and takes account of investment, patient engagement, incentives and pricing, and legislation. These categories are further subdivided with examples demonstrating such qual- 
ities and activities that are required to deliver personalised health care to the citizen that include leadership, funding, partnerships, data standards, monitoring, clinical trials, or outcome-based payment models.

Examples of the achievements listed below range from the Estonian EU Presidency's focus on digital health in 2017 to the European Institute of Innovation and Technology's health initiative that connects 90 partners from public and private organisations to accelerate innovation and development of health services by sharing best practice, and from managed entry agreements with the Italian Medicines Agency in which reimbursement for innovative medicines is conditional on agreed outcomes to Germany's 2019 Digital Care Act allowing doctors to prescribe digital apps with health benefits that can be reimbursed.

A conference on personalised medicine under the auspices of the Irish EU Presidency in 2013 resulted in a report that highlighted the necessary conditions if the potential of personalised health care is to be realised: "Changes will be necessary in the way medicines are developed, regulated, and rewarded. Greater collaboration will be needed across a wide range of actors in health care. And systems will need to catch up with science" [149]. That report, set alongside the compendium in the table, has allowed us to define a road map with a checklist that reveals how far the personalized medicine context has improved by 2021. One conclusion that can be drawn is of a growing momentum towards radical rethinking and political support for opening up health systems to new opportunities. At the same time, the list of successes indicated still amounts to only a fraction of the distance to be travelled for full exploitation of personalised health care's potential. Progress, yes, but with much progress still to be made.

Personalised health care is a means to an end, which is better health care and health. It is not the only means to reach this end, and policies for its development must be developed in a broad context. But its success will also depend on a more precise definition of how it can contribute to the desired end.

For an economist, personalised health care is about using information to improve decisions for individual patients. This is what doctors always have done. The new elements are the wider opportunities to gather information - with all the associated costs of producing, storing and analysing additional data - and improved understanding of how the additional information can improve decision-making and outcome for patients. There are many choices, and making the correct choices will require judgement, often on a case-by-case basis. So, in addition to the data to guide decisions, the right incentives will also be needed to ensure an appropriate trade-off between costs and benefits.

It will be equally important for policymakers to find a new reconciliation between the intrinsic tensions between public and private interests. Development of personalised health care and targeted therapies is driven by private for-profit firms, which look for market opportunities for new tests and therapies, while prices are paid by health care systems and indirectly the tax payers. This model for innovation is the best available so far, but it is not without its problems, and needs complementary public regulation and research to find its full potential.

Famously, the Scottish biologist Alexander Fleming accidentally discovered the antibacterial "mould" in a Petri dish in 1928. That came at the tail-end of the "roaring twenties" and led to a revolution in health care over subsequent decades. Now, a century later, thoughtful policymakers who are able to see the potential merits of personalised care and targeted therapies are on the threshold of an even greater revolution. If they are able to find ways of integrating these new opportunities into the changes they are making in their own health care systems, the result could be a new age of the "roaring twenties"! 
Horgan et al.: Propelling Health Care into the Twenties

\section{Acknowledgements}

We would like to thank the members of the Million European Genome Alliance+ (MEGA+), the Future-Proofing initiative and give thanks to the contribution from the consortium of Digital Health Europe: Support to a Digital Health and Care Innovation initiative in the context of Digital Single Market strategy.

\section{Disclosure Statement}

The authors declare that they have no competing interests.

\section{Author Contributions}

D.H. conceived, built, and drafted the article with critical input from his co-authors, expert interviews and MEGA+ partners.

\section{References}

1 von der Leyen U. A union that strives for more - my agenda for Europe [cited 2020 Jan 24]. Available from: https://ec.europa.eu/commission/sites/beta-political/files/political-guidelines-next-commission_en.pdf

2 Answer to the European Parliament - questionnaire to the commissioner-designate Stella Kyriakides [cited 2020 Jan 24]. Available from: https://www.europarl.europa.eu/resources/library/media/20190927RES624 29/20190927RES62429.pdf

3 State of Health in the EU - companion report 2019, European Union 2019. DOI: 10.2875/85326. EW-01-19848-EN-N

4 Answer to the European Parliament - questionnaire to the commissioner-designate Stella Kyriakides. Cited January 24, 2020. Available from: https://www.europarl.europa.eu/resources/library/media/20190927RE S62429/20190927RES62429.pdf

5 State of Health in the EU - companion report 2019, European Union 2019. DOI: 10.2875/85326. EW-01-19848-EN-N.

6 Bengt J, Sullivan R. Mission-oriented translational cancer research - health economics. Mol Oncol. 2019 Mar; 13(3):636-47.

7 Roche. Future-proofing healthcare [cited 2020 Jan 24]. Available from: https://futureproofinghealthcare.com

8 Roche. Future-proofing healthcare, the breast cancer index [cited 2020 Jan 24]. Available from: https:// futureproofinghealthcare.com/breast-cancer-index

9 Roche. Future-proofing healthcare, the multiple sclerosis index [cited 2020 Jan 24]. Available from: https:// futureproofinghealthcare.com/multiple-sclerosis-index

10 Roche. Future-proofing healthcare, sustainability index [cited 2020 Jan 24]. Available from: https://futureproofinghealthcare.com/sustainability-index

11 State of health in the EU - companion report 2019, European Union 2019. DOI: 10.2875/85326. EW-01-19848-EN-N. p. 5.

12 State of health in the EU - companion report 2019, European Union 2019. DOI: 10.2875/85326. EW-01-19848-EN-N. p. 54.

13 State of health in the EU - companion report 2019, European Union 2019. DOI: 10.2875/85326. EW-01-19848-EN-N. p. 55.

14 State of health in the EU - companion report 2019, European Union 2019. DOI: 10.2875/85326. EW-01-19848-EN-N. p. 59.

15 State of health in the EU - companion report 2019, European Union 2019. DOI: 10.2875/85326. EW-01-19848-EN-N. p. 64.

16 State of health in the EU - companion report 2019, European Union 2019. DOI: 10.2875/85326. EW-01-19848-EN-N. p. 69.

17 State of health in the EU - companion report 2019, European Union 2019. DOI: 10.2875/85326. EW-01-19848-EN-N. p. 74.

18 State of health in the EU - companion report 2019, European Union 2019. DOI: 10.2875/85326. EW-01-19848-EN-N. p. 82.

19 State of health in the EU - companion report 2019, European Union 2019. DOI: 10.2875/85326. EW-01-19848-EN-N. p. 76. 
20 State of health in the EU - companion report 2019, European Union 2019. DOI: 10.2875/85326. EW-01-19848-EN-N. p. 56.

21 State of health in the EU - companion report 2019, European Union 2019. DOI: 10.2875/85326. EW-01-19848-EN-N. p. 57.

22 State of health in the EU - companion report 2019, European Union 2019. DOI: 10.2875/85326. EW-01-19848-EN-N. p. 60.

23 State of health in the EU - companion report 2019, European Union 2019. DOI: 10.2875/85326. EW-01-19848-EN-N. p. 62-64.

24 State of health in the EU - companion report 2019, European Union 2019. DOI: 10.2875/85326. EW-01-19848-EN-N. p. 36.

25 State of health in the EU - companion report 2019, European Union 2019. DOI: 10.2875/85326. EW-01-19848-EN-N. p. 16.

26 Bengt J, Sullivan R. Mission-oriented translational cancer research - health economics. Mol Oncol. https://doi. org/10.1002/1878-0261.12440.

27 State of health in the EU - companion report 2019, European Union 2019. DOI: 10.2875/85326. EW-01-19848-EN-N. p. 46.

28 The EU Health Coalition highlights the need for concreate measures for better health for people in light of the publication of the State of Health in the EU [cited 2020 Jan 24]. Available from: https://www.euhealthcoalition.eu/news/the-eu-health-coalition-highlights-the-need-for-concrete-measures-for-better-healthfor-people-in-light-of-the-publication-of-the-state-of-health-in-the-eu/

29 State of health in the EU - companion report 2019, European Union 2019. DOI: 10.2875/85326. EW-01-19848-EN-N. p. 5.

30 Answer to the European Parliament - questionnaire to the commissioner-designate Mariya Gabriel [cited 2020 Jan 24]. Available from: https://www.europarl.europa.eu/resources/library/media/20190927RES624 43/20190927RES62443.pdf

31 Ibid

32 Answer to the European Parliament - questionnaire to the commissioner-designate Stella Kyriakides [cited 2020 Jan 24]. Available from: https://www.europarl.europa.eu/resources/library/media/20190927RES624 29/20190927RES62429.pdf

33 State of health in the EU - companion report 2019, European Union 2019. DOI: 10.2875/85326. EW-01-19848-EN-N. p. 46.

34 Answer to the European Parliament - questionnaire to the commissioner-designate Thierry Breton [cited 2020 Jan 24]. Available from: https://ec.europa.eu/commission/commissioners/sites/comm-cwt2019/ files/commissioner_ep_hearings/answers-ep-questionnaire-breton.pdf

35 Ibid

36 von der Leyen U. Mission letter to Mariya Gabriel, commissioner-designate for innovation and youth [cited 2020 Jan 24]. Available from: https://ec.europa.eu/commission/sites/beta-political/files/mission-lettermariya-gabriel-2019_en.pdf

37 Answer to the European Parliament - questionnaire to the commissioner-designate Mariya Gabriel [cited 2020 Jan 24]. Available from: https://www.europarl.europa.eu/resources/library/media/20190927RES624 43/20190927RES62443.pdf

38 von der Leyen U. A Union that strives for more - my agenda for Europe [cited 2020 Jan 24]. Available from: https://ec.europa.eu/commission/sites/beta-political/files/political-guidelines-next-commission_en.pdf

39 Answer to the European Parliament - questionnaire to the commissioner-designate Thierry Breton [cited 2020 Jan 24]. Available from: https://ec.europa.eu/commission/commissioners/sites/comm-cwt2019/ files/commissioner_ep_hearings/answers-ep-questionnaire-breton.pdf

40 von der Leyen U. Mission letter to Stella Kyriakides, commissioner-designate for health .[cited 2020 Jan 24]. Available from: https://ec.europa.eu/commission/sites/beta-political/files/mission-letter-stella-kyriakides_en.pdf

41 Answer to the European Parliament - questionnaire to the commissioner-designate Stella Kyriakides [cited 2020 Jan 24]. Available from: https://www.europarl.europa.eu/resources/library/media/20190927RES624 29/20190927RES62429.pdf

42 von der Leyen U. Mission letter to Mariya Gabriel, commissioner-designate for Innovation and youth [cited 2020 Jan 24]. Available from: https://ec.europa.eu/commission/sites/beta-political/files/mission-lettermariya-gabriel-2019_en.pdf

43 Answer to the European Parliament - questionnaire to the commissioner-designate Mariya Gabriel [cited 2020 Jan 24]. Available from: https://www.europarl.europa.eu/resources/library/media/20190927RES624 43/20190927RES62443.pdf

44 Answer to the European Parliament - questionnaire to the commissioner-designate Stella Kyriakides [cited 2020 Jan 24]. Available from: https://www.europarl.europa.eu/resources/library/media/20190927RES624 29/20190927RES62429.pdf

45 Communication from the Commission to the European Parliament, the Council, the European Central Bank, the European Economic and Social Committee, the Committee of the Regions and the European Investment Bank. Annual growth survey 2019: for stronger Europe in the face of a global uncertainty. Brussels, 21.11.2018. COM (2018) 770 final [cited 2020 Jan 24]. Available from: https://eur-lex.europa.eu/legal-content/EN/TXT/ PDF/?uri=CELEX:52018DC0770\&from=EN 
Horgan et al.: Propelling Health Care into the Twenties

46 State of health in the EU - companion report 2019, European Union 2019. DOI: 10.2875/85326. EW-01-19848-EN-N. p. 47.

47 Answer to the European Parliament - questionnaire to the commissioner-designate Stella Kyriakides [cited 2020 Jan 24]. Available from: https://www.europarl.europa.eu/resources/library/media/20190927RES624 29/20190927RES62429.pdf

48 State of health in the EU - companion report 2019, European Union 2019. DOI: 10.2875/85326. EW-01-19848-EN-N. p. 46.

49 Answer to the European Parliament - questionnaire to the commissioner-designate Stella Kyriakides [cited 2020 Jan 24]. Available from: https://www.europarl.europa.eu/resources/library/media/20190927RES624 29/20190927RES62429.pdf

50 Ibid

51 State of health in the EU - companion report 2019, European Union 2019. DOI: 10.2875/85326. EW-01-19848-EN-N. p. 45.

52 Answer to the European Parliament - questionnaire to the commissioner-designate Stella Kyriakides [cited 2020 Jan 24]. Available from: https://www.europarl.europa.eu/resources/library/media/20190927RES624 29/20190927RES62429.pdf

53 European Commission, Health and Food Safety Director-General, Pharmaceutical Committee. Pharmaceutical Committee: mapping policy needs and working method, 7 November 2019, PHARM 777 [cited 2020 Jan 24]. Available from: https://ec.europa.eu/health/sites/health/files/files/committee/pharm777_policy-needs_ en.pdf

54 von der Leyen U. Mission letter to Stella Kyriakides, commissioner-designate for health [cited 2020 Jan 24]. Available from: https://ec.europa.eu/commission/sites/beta-political/files/mission-letter-stella-kyriakides_en.pdf

55 Answer to the European Parliament - questionnaire to the commissioner-designate Stella Kyriakides [cited 2020 Jan 24]. Available from: https://www.europarl.europa.eu/resources/library/media/20190927RES624 29/20190927RES62429.pdf

56 Answer to the European Parliament - questionnaire to the commissioner-designate Stella Kyriakides [cited 2020 Jan 24]. Available from: https://www.europarl.europa.eu/resources/library/media/20190927RES624 29/20190927RES62429.pdf

57 von der Leyen U. Mission letter to Mariya Gabriel, commissioner-designate for innovation and youth [cited 2020 Jan 24]. Available from: https://ec.europa.eu/commission/sites/beta-political/files/mission-lettermariya-gabriel-2019_en.pdf

58 Answer to the European Parliament - questionnaire to the commissioner-designate Mariya Gabriel [cited 2020 Jan 24]. Available from: https://www.europarl.europa.eu/resources/library/media/20190927RES624 43/20190927RES62443.pdf

59 von der Leyen U. Mission letter to Mariya Gabriel, commissioner-designate for innovation and youth [cited 2020 Jan 24]. Available from: https://ec.europa.eu/commission/sites/beta-political/files/mission-lettermariya-gabriel-2019_en.pdf

60 Answer to the European Parliament - questionnaire to the commissioner-designate Mariya Gabriel [cited 2020 Jan 24]. Available from: https://www.europarl.europa.eu/resources/library/media/20190927RES624 43/20190927RES62443.pdf

61 Answer to the European Parliament - questionnaire to the commissioner-designate Stella Kyriakides [cited 2020 Jan 24]. Available from: https://www.europarl.europa.eu/resources/library/media/20190927RES624 29/20190927RES62429.pdf

62 von der Leyen U. Mission letter to Stella Kyriakides, commissioner-designate for health [cited 2020 Jan 24]. Available from: https://ec.europa.eu/commission/sites/beta-political/files/mission-letter-stella-kyriakides_en.pdf

63 Answer to the European Parliament - questionnaire to the commissioner-designate Stella Kyriakides [cited 2020 Jan 24]. Available from: https://www.europarl.europa.eu/resources/library/media/20190927RES624 29/20190927RES62429.pdf

64 State of health in the EU - companion report 2019, European Union 2019. DOI: 10.2875/85326. EW-01-19848-EN-N. p. 8.

65 Communication from the Commission to the European Parliament, the Council, the European Economic and Social Committee and the Committee of the Regions. A European strategy for data. 19.2.2020 COM(2020) 66 Final [cited 2020 Mar 5]. Available from: https://ec.europa.eu/info/sites/info/files/communicationeuropean-strategy-data-19feb2020_en.pdf

66 von der Leyen U. Mission letter to Sylvie Goulard, commissioner-designate for internal market [cited 2020 Jan 24]. Available from: https://ec.europa.eu/commission/sites/beta-political/files/mission-letter-sylviegoulard_en.pdf

67 Answer to the European Parliament - questionnaire to the commissioner-designate Mariya Gabriel [cited 2020 Jan 24]. Available from: https://www.europarl.europa.eu/resources/library/media/20190927RES624 43/20190927RES62443.pdf

68 Answer to the European Parliament - questionnaire to the commissioner-designate Thierry Breton [cited 2020 Jan 24]. Available from: https://ec.europa.eu/commission/commissioners/sites/comm-cwt2019/ files/commissioner_ep_hearings/answers-ep-questionnaire-breton.pdf 
69 Answer to the European Parliament - questionnaire to the commissioner-designate Stella Kyriakides [cited 2020 Jan 24]. Available from: https://www.europarl.europa.eu/resources/library/media/20190927RES624 29/20190927RES62429.pdf

70 von der Leyen U. Mission letter to Stella Kyriakides, commissioner-designate for health [cited 2020 Jan 24]. Available from: https://ec.europa.eu/commission/sites/beta-political/files/mission-letter-stella-kyriakides_en.pdf

71 Commission recommendation of 6.2.2019 on a European electronic health record exchange format. Brussels, 6.2.2019 C(2019) 800 final [cited 2020 Apr 23]. Available from: https://eur-lex.europa.eu/legal-content/EN/ TXT/PDF/?uri=CELEX:32019H0243\&from=EN

72 State of health in the EU - companion report 2019, European Union 2019. DOI: 10.2875/85326. EW-01-19848-EN-N. p. 8.

73 von der Leyen U. Mission letter to Mariya Gabriel, commissioner-designate for innovation and youth [cited 2020 Jan 24]. Available from: https://ec.europa.eu/commission/sites/beta-political/files/mission-lettermariya-gabriel-2019_en.pdf

74 Answer to the European Parliament - questionnaire to the commissioner-designate Stella Kyriakides [cited 2020 Jan 24]. Available from: https://www.europarl.europa.eu/resources/library/media/20190927RES624 29/20190927RES62429.pdf

75 Report EU Health Coalition. The EU health coalition highlights the need for concrete measures for better health for people in light of the publication of the state of health in the EU [cited 2020 Jan 24]. Available from: https://www.euhealthcoalition.eu/news/the-eu-health-coalition-highlights-the-needfor-concrete-measures-for-better-health-for-people-in-light-of-the-publication-of-the-state-of-health-inthe-eu/

76 von der Leyen U. Mission letter to Thierry Breton, commissioner-designate for internal market [cited 2020 Jan 24]. Available from: https://ec.europa.eu/commission/sites/beta-political/files/president-elect_von_ der_leyens_mission_letter_to_thierry_breton.pdf

77 Answer to the European Parliament - questionnaire to the commissioner-designate Thierry Breton [cited 2020 Jan 24]. Available from: https://ec.europa.eu/commission/commissioners/sites/comm-cwt2019/ files/commissioner_ep_hearings/answers-ep-questionnaire-breton.pdf

78 von der Leyen U. Mission letter to Stella Kyriakides, commissioner-designate for health [cited 2020 Jan 24]. Available from: https://ec.europa.eu/commission/sites/beta-political/files/mission-letter-stella-kyriakides_en.pdf

79 Communication from the Commission to the European Parliament, the Council, the European Central Bank, the European Economic and Social Committee, the Committee of the Regions and the European Investment Bank. Annual growth survey 2019: for stronger Europe in the face of a global uncertainty. Brussels, 21.11.2018. COM (2018) 770 final [cited 2020 Jan 24]. Available from: https://eur-lex.europa.eu/legal-content/EN/TXT/ PDF/?uri=CELEX:52018DC0770\&from=EN

80 State of health in the EU - companion report 2019, European Union 2019. DOI: 10.2875/85326. EW-01-19848-EN-N.

812019 annual review from the Social Protection Committee. Review of the social situation and the development in the social protection policies in the Member States and the Union. DOI: 10.2767/963589. KE-BG-19-001-ENN.

82 Answer to the European Parliament - questionnaire to the commissioner-designate Mariya Gabriel [cited 2020 Jan 24]. Available from: https://www.europarl.europa.eu/resources/library/media/20190927RES624 43/20190927RES62443.pdf

83 NHS. Health data research hubs [cited 2020 Mar 5]. Available from: https://digital.nhs.uk/blog/transformation-blog/2019/welcoming-new-health-data-research-hubs

84 Shaping Europe's digital future, webinar: Estonia EU presidency 2017 and digital health [cited 2020 Mar 5]. Available from: https://ec.europa.eu/digital-single-market/en/news/webinar-estonian-eu-presidency2017-and-digital-health

85 Department of Health. Commonwealth of Australia, implementation plan - national health genomics policy framework [cited 2020 Mar 5]. Available from: https://www1.health.gov.au/internet/main/publishing.nsf/ Content/FD973B58DE82BCFFCA2581CC007D4682/\$File/Implementation-Plan-to-the-Framework.pdf

86 Digital health ecosystem in Singapore. Q4 [cited 2020 Mar 5]. Available from: http://www.resourceleaders. com/blog/2017/11/6/digital-health-ecosystem-in-singapore

87 Australia Government, Department of Health. Genomics health futures mission [cited 2020 Mar 5]. Available from: https://www.health.gov.au/initiatives-and-programs/genomics-health-futures-mission

88 European Patients Forum. Data saves lives [cited 2020 Mar 5]. Available from: https://www.eu-patient.eu/ News/News/data-saves-lives/

89 Health literacy Europe - a network for advancing European health literacy [cited 2020 Mar 5]. Available from: https://www.healthliteracyeurope.net/national-hl-networks

90 NHS. Widening digital participation [cited 2020 Mar 5]. Available from: https://digital.nhs.uk/about-nhsdigital/our-work/transforming-health-and-care-through-technology/empower-the-person-formerlydomain-a/widening-digital-participation

91 UCL. Personalised medicine and novel therapies MSc [cited 2020 Mar 5]. Available from: https://www.ucl. ac.uk/prospective-students/graduate/taught-degrees/personalised-medicine-novel-therapies-msc 
Horgan et al.: Propelling Health Care into the Twenties

92 European Commission. Study report 2010, interoperable e-health is worth it - securing benefits from electronic health records and e-prescribing [cited 2020 Mar 5]. Available from: https://www.ifap.ru/library/ book476.pdf

93 Curioso WH. Building capacity and training for digital health: challenges and opportunities in Latin America. J Med Internet Res. 2019 Dec;21(12):e16513.

94 Support for health workforce planning and forecasting expert network [cited 2020 Mar 5]. Available from: http://healthworkforce.eu/about-us/

95 Deloitte Centre for Solutions. Vital signs - how to deliver better healthcare across Europe, July 2016 [cited 2020 Mar 5]. Available from: https://www2.deloitte.com/content/dam/Deloitte/global/Documents/LifeSciences-Health-Care/gx-lshc-vital-signs-uk-healthcare-across-europe.pdf

96 Ibid

97 Masschallenge healthtech - programme benefit [cited 2020 Mar 5]. Available from: https://masschallenge. org/programs-healthtech

98 Sekhri N, Feachem R, Ni A. Public-private integrated partnership to improve health care access, quality, and efficiency. Health Affairs. 2011;30(8):1498-507.

99 WHO. Brazilian industrial and innovation complex in health: productive development partnership (PDP) to guarantee access to health technologies in Brazil [cited 2020 Mar 5]. Available from: https://www.who.int/ medical_devices/global_forum/J01.pdf

100 Department of Health. Government invests \$5 million in lung cancer research [cited 2020 Mar 5]. Available from: https://www.health.gov.au/ministers/the-hon-greg-hunt-mp/media/government-invests-5-millionin-lung-cancer-research

101 Incentive-based systems to improve patient compliance: interview with Matt Loper, CEO of Wellth [cited 2020 Mar 5]. Available from: https://www.medgadget.com/2017/08/incentive-based-systems-improve-patientcompliance-interview-matt-loper-ceo-wellth.html

102 At Mount Sinai monetary incentives drive medication adherence [cited 2020 Mar 5]. Available from: https:// www.mobihealthnews.com/content/mount-sinai-monetary-incentives-drive-medication-adherence

103 Deloitte Centre for Solutions. Vital signs - how to deliver better healthcare across Europe, July 2016 [cited 2020 Mar 5]. Available from: https://www2.deloitte.com/content/dam/Deloitte/global/Documents/LifeSciences-Health-Care/gx-lshc-vital-signs-uk-healthcare-across-europe.pdf

104 Human Brain Project - the medical informatics platform [cited 2020 Mar 5]. Available from: https://www. humanbrainproject.eu/en/medicine/medical-informatics-platform/

105 Korean Biomedical Review. IFEZ unveils plan for world's largest bio-health complex [cited 2020 Mar 5]. Available from: http://www.koreabiomed.com/news/articleView.html?idxno=2533

106 HMA-EMA Joint Big Data Taskforce. Summary report [cited 2020 Mar 5]. Available from: https://www.ema. europa.eu/en/documents/minutes/hma/ema-joint-task-force-big-data-summary-report_en.pdf

107 Strategie digitale Schweiz - Aktionsplan [cited 2020 Mar 5]. Available from: https://strategy.digitaldialog. swiss/aktionsplan

108 Ministry of Social Affairs and Health Finland. Secondary use of health and social data [cited 2020 Mar 5]. Available from: https://stm.fi/en/secondary-use-of-health-and-social-data

109 Observational Health Data Sciences and Informatics [cited 2020 Mar 5]. Available from: https://www.ohdsi. org/web/wiki/doku.php?id=welcome

110 Deloitte Centre for Solutions. Vital signs - how to deliver better healthcare across Europe, July 2016 [cited 2020 Mar 5]. Available from: https://www2.deloitte.com/content/dam/Deloitte/global/Documents/LifeSciences-Health-Care/gx-lshc-vital-signs-uk-healthcare-across-europe.pdf

111 Open data dashboard [cited 2020 Mar 5]. Available from: https://doh.gov.ae/resources/opendata

112 European "1+ Million Genomes" initiative [cited 2020 Mar 5]. Available from: https://ec.europa.eu/digitalsingle-market/en/european-1-million-genomes-initiative

113 Moon-hee C. Korea government comes up with bio-health industry innovation solution. Business Korea [cited 2020 Mar 5]. Available from: http://www.businesskorea.co.kr/news/articleView.html?idxno=32128

114 Iridium Interactive - ehealth solutions @ scale [cited 2020 Mar 5]. Available from: http://www.iridiuminteractive.com/solutions/ehealth/

115 Deloitte Centre for Solutions. Vital signs - how to deliver better healthcare across Europe, July 2016 [cited 2020 Mar 5]. Available from: https://www2.deloitte.com/content/dam/Deloitte/global/Documents/LifeSciences-Health-Care/gx-lshc-vital-signs-uk-healthcare-across-europe.pdf

116 European Commission. Study report 2010, interoperable e-health is worth it - securing benefits from electronic health records and e-prescribing [cited 2020 Mar 5]. Available from: https://www.ifap.ru/library/book476.pdf

117 European Commission. Interoperability and standardisation: connecting eHealth services [cited 2020 Mar 5]. Available from: https://ec.europa.eu/digital-single-market/en/interoperability-standardisation-connectingehealth-services

118 Genomics England. The 100,000 Genomes Project [cited 2020 Mar 5]. Available from: https://www.genomicsengland.co.uk/about-genomics-england/the-100000-genomes-project/

119 Access to biobank, University of Tartu [cited 2020 Mar 5]. Available from: https://genomics.ut.ee/en/accessbiobank

120 Harrell E. In Denmark's electronic health records program, a lesson for the US [cited 2020 Mar 5]. Available from: http://content.time.com/time/health/article/0,8599,1891209,00.html 
121 Halim S. Learning from the Estonian e-health system [cited 2020 Mar 5]. Available from: https://www.healtheuropa.eu/estonian-e-health-system/89750/

122 LC-SCRUM Japan expands genomic screening project to Taiwan and establishes LC-SCRUM Asia [cited 2020 Mar 5]. Available from: https://www.globenewswire.com/news-release/2019/05/31/1861108/0/ en/LC-SCRUM-Japan-Expands-Genomic-Screening-Project-to-Taiwan-and-Establishes-LC-SCRUM-Asia. html

123 Just what the devil is population-based care? Managed Care [cited 2020 Mar 5]. Available from: https://www. managedcaremag.com/archives/1998/9/just-what-devil-population-based-care

124 Babylon [cited 2020 Mar 5]. Available from: https://www.babylonhealth.com/

125 Adoption of wearable devices in Dubai, May 2018 [cited 2020 Mar 5]. Available from: https://www. researchgate.net/publication/325313840_ADOPTION_OF_WEARABLE_DEVICES_IN_DUBAI

126 China pushes the use of medical AI. Intelligence Health 2019 [cited 2020 Mar 5]. Available from: https:// healthcare-in-europe.com/en/news/china-pushes-the-use-of-medical-ai.html

127 Ping An good doctor launches "private doctor" service [cited 2020 Mar 5]. Available from: https://www.mobihealthnews.com/content/asia-pacific/ping-good-doctor-launches-private-doctor-service

128 M-Health solutions - NHP India [cited 2020 Mar 5]. Available from: https://www.nhp.gov.in/miscellaneous/ m-health

129 A web platform to monitor global standards for quality of health-care services for adolescents [cited 2020 Mar 5]. Available from: https://www.who.int/maternal_child_adolescent/adolescence/global-standards-monitoring/en/

130 Martini-Klinik: patient-centred outcomes data collection to improve prostate cancer care [cited 2020 Mar 5]. Available from: https://www.all-can.org/efficiency-hub/martini-klinik-patient-centred-outcomes-datacollection-to-improve-prostate-cancer-care/

131 How Dutch hospitals make value-based health care work. June 13, 2018 [cited 2020 Mar 5]. Available from: https://www.bcg.com/publications/2018/how-dutch-hospitals-make-value-based-health-care-work.aspx

132 Deloitte Centre for Solutions. Vital signs - how to deliver better healthcare across Europe, July 2016 [cited 2020 Mar 5]. Available from: https://www2.deloitte.com/content/dam/Deloitte/global/Documents/LifeSciences-Health-Care/gx-lshc-vital-signs-uk-healthcare-across-europe.pdf

133 Pravettoni G, Gorini A. A P5 cancer medicine approach: why personalized medicine cannot ignore psychology. J Eval Clin Pract. 2011 Aug;17(4):594-6.

134 Kazantzaki Ei, et al. Psycho-emotional tools for better treatment adherence and therapeutic outcomes for cancer patients. pHealth. 2016;2016:129-34.

135 Domixity [cited 2020 Mar 5]. Available from: https://www.doximity.com/about/faq

136 National health genomics policy framework and implementation plan 2018-2021 [cited 2020 Mar 5]. Available from: https://www1.health.gov.au/internet/main/publishing.nsf/Content/national-healthgenomics-policy-framework-2018-2021

137 Global Observatory for eHealth series - Vol 5: Legal frameworks for eHealth [cited 2020 Mar 5]. Available from: https://www.who.int/goe/publications/legal_framework_web.pdf

138 DNAnezus' new solution integrates next-generation sequencing data in clinical trials [cited 2020 Mar 5]. Available from: https://www.fiercebiotech.com/cro/dnanexus-new-solution-integrates-next-generationsequencing-data-clinical-trials

139 21st century cures act [cited 2020 Mar 5]. Available from: https://www.fda.gov/regulatory-information/ selected-amendments-fdc-act/21st-century-cures-act

140 FDA and European Medicines Agency Patient Engagement Cluster. Cited March 5, 2020, Available from: https://www.fda.gov/patients/learn-about-fda-patient-engagement/fda-and-european-medicines-agencypatient-engagement-cluster

1413 défis pour 2019: l'accès des patients à l'innovation, la reconquête industrielle, et l'amélioration de la réputation du secteur [cited 2020 Mar 5]. Available from: https://www.leem.org/sites/ default/files/2019-01/Discours\%20Voeux\%20P.T\%202019\%20VF\%2014-01-2019\%20version\%20 journalistes\%20v2.pdf

142 Germany's new law allows doctors to prescribe apps with health benefits, July 11, 2019 [cited 2020 Mar 5]. Available from: https://pharmaphorum.com/news/germanys-new-law-allows-doctors-to-prescribe-appswith-health-benefits/

143 ISPOR. Sweden pharmaceutical - global health technology assessment road map [cited 2020 Mar 5]. Available from: https://tools.ispor.org/htaroadmaps/Sweden.asp

144 Supplier registration and prequalification. Dubai Health Authority [cited 2020 Mar 5]. Available from: https:// www.dha.gov.ae/en/ServiceCatalogue/Pages/ScServiceDetails.aspx?ServiceID=84\&bclevel=tlvlbc

145 Italian Medicines Agency [cited 2020 Mar 5]. Available from: http://www.agenziafarmaco.gov.it/content/ comunicazioni-managed-entry-agreements-mea

146 Oliveri S, Masiero M, Arnaboldi P, Cutica I, Fioretti C, Pravettoni G. Health orientation, knowledge, and attitudes toward genetic testing and personalized genomic services: preliminary data from an Italian sample. Biomed Res Int. 2016;2016:6824581.

147 Philips and Atrium sign innovative risk-sharing agreement for the care of patients with peripheral vascular disease [cited 2020 Mar 5]. Available from: https://www.usa.philips.com/a-w/about/news/archive/ standard/news/articles/20181102-philips-and-atrium-health-sign-patient-care-agreement.html 
148 Health care in Kingdom of Saudi Arabia. United National Platform [cited 2020 Mar 5]. Available from: https:// www.my.gov.sa/wps/portal/snp/aboutksa/HealthCareInKSA/!ut/p/z0/04_Sj9CPykssy0xPLMnMz0vMAfIjo8zivQN9DDycTAz9LZxCHQ0CA91MQyzMgo0NLEz0g1Pz9AuyHRUBpZYTgA!!/

149 EAPM report from Irish presidency conference, March 20th/21st 2013 - innovation and patient access to personalised medicine [cited 2020 Mar 5]. Available from: https://euapm.eu/pdf/EAPM_REPORT_on_Innovation_and_Patient_Access_to_Personalised_Medicine.pdf

150 Horgan D, Bernini C, et al. Cooperating on data: the missing element in bringing real innovation to Europe's healthcare systems. Public Health Genomics. 2019;22:77-101.

151 European Commission. European innovation scoreboard 2019. DOI: 10.2873/877069.

152 Nimmesgern E, Norstedt I, Draghia-Akli R. Enabling personalised medicine in Europe by the European Commission's funding activities. Per Med. 2017 Jul;14(4):355-65.

153 WHO. European health information gateway, 2020 [cited 2020, Mar 5]. Available from: https://gateway.euro. who.int/en/indicators/hfa_3 75-2350-incidence-of-female-breast-cancer-per-100-000/ visualizations/\#id=19306

154 Roche. Future-proofing healthcare: the multiple sclerosis index [cited 2020, Mar 5]. Available from: https:// futureproofinghealthcare.com/multiple-sclerosis-index.

155 European Commission. Graph of the week: fiscal sustainability of health care and long-term care systems [cited 2020, Mar 17]. Available from: https://ec.europa.eu/economy_finance/graphs/2016-10-07_health_ care_system_sustainability_en.htm

156 European Commission. State of health in the EU - companion report 2019. Brussels: European Union; 2019.

157 IQVIA. EFPIA patient W.A.I.T indicator 2018 survey. Durham: IQVIA; 2019.

158 Pharmaceutical Committee. Mapping policy needs and working method. 84th meeting of the Pharmaceutical Committee, 7 November 2019.

159 European Commission. Connected for a healthy future. Brussels: European Commission; 18 September 2019. 